\title{
Iron (II/III) Halide Complexes Promote the Interconversion of Nitric Ox- ide and S-nitrosothiols through Reversible Fe-S Interaction
}

\author{
Anna L. Poptic, ${ }^{\dagger}$ and Shiyu Zhang ${ }^{*}+$ \\ ${ }^{\dagger}$ Department of Chemistry \& Biochemistry, The Ohio State University, 100 West $18^{\text {th }}$ Avenue, Columbus, Ohio 43210 , \\ United States
}

\begin{abstract}
Heme and non-heme iron in biology mediate the storage/release of $\mathrm{NO}^{*}$ from $S$-nitrosothiols as a means to control the biological concentration of $\mathrm{NO}^{*}$. Despite their importance in many physiological processes, the mechanisms of N-S bond formation/cleavage at Fe centers have been controversial. Herein, we report the interconversion of $\mathrm{NO}^{*}$ and $S$-nitrosothiols mediated by $\mathrm{Fe}^{\mathrm{II}} / \mathrm{Fe}^{\mathrm{III}}$ chloride complexes. The reaction of two equivalents of $S$-nitrosothiol $\left(\mathrm{Ph}_{3} \mathrm{CSNO}\right)$ with $\left[\mathrm{Cl}_{6} \mathrm{Fe}^{\mathrm{II}}{ }_{2}\right]^{2-}$ results in facile release of NO and formation of iron(III) halothiolate. Detailed spectroscopic studies, including in situ UV-vis, IR, and Mössbauer spectroscopy, support the interaction of the $\mathrm{S}$-atom with the $\mathrm{Fe}^{\mathrm{II}}$ center. This is in contrast to the proposed mechanism of NO release from the well-studied "red product" $\kappa^{1}-\mathrm{N}$ bound $S$-nitrosothiol $\mathrm{Fe}^{\mathrm{II}}$ complex, $\left[(\mathrm{CN})_{5} \mathrm{Fe}\left(\kappa^{1}-\mathrm{N}-\mathrm{RSNO}\right)\right]^{3-}$. Additionally, $\mathrm{Fe}^{\mathrm{III}}$ chloride can mediate NO" storage through the formation of $S$-nitrosothiols. Treatment of iron(III) halothiolate with two equivalents of NO" regenerates $\mathrm{Ph}_{3} \mathrm{CSNO}$ with the $\mathrm{Fe}^{\mathrm{II}}$ source trapped as the $S=3 / 2\{\mathrm{FeNO}\}^{7}$ species $\left[\mathrm{Cl}_{3} \mathrm{FeNO}\right]^{-}$, which is inert towards further coordination and activation of $S$-nitrosothiols. Our work demonstrates how labile iron can mediate the interconversion of NO/thiolate and $S$ nitrosothiol, which has important implications for how Nature manages the biological concentration of free NO".
\end{abstract}

\section{INTRODUCTION}

Nitric oxide (NO*) is a crucial secondary signaling molecule responsible for the regulation of a range of biological processes, including immune response, smooth muscle relaxation, and neurotransmission. ${ }^{1}$ However, $\mathrm{NO}^{\bullet}$ has a short lifetime in vivo and quickly reacts with the bio-available oxygen and superoxide, forming reactive oxygen and reactive nitrogen species. ${ }^{2}$ To mitigate the formation of these reactive species, Nature has developed specific regulatory strategies that store $\mathrm{NO}^{\circ}$ as air-stable $S$-nitrosothiols (RSNOs). ${ }^{3}$ RSNOs can also serve as signaling molecules to participate in the $S$-nitrosation of proteins, which is a precisely regulated post-translational modification. Dysregulation of RSNO homeostasis has been linked to several diseases, such as Alzheimer's disease and Parkinson's disease, cancer, diabetes, etc.. ${ }^{4,5}$

Formation of $S$-nitrosothiols from free $\mathrm{NO}^{\circ}$ and thiol requires one-electron oxidation, which can be facilitated by the singleelectron accepting abilities of $\mathrm{Fe}^{\mathrm{III}}$ or $\mathrm{Cu}^{\mathrm{II}}$. Conversely, $\mathrm{Fe}^{\mathrm{II}}$ and $\mathrm{Cu}^{\mathrm{I}}$ can act as one-electron reducing agents to promote the release of $\mathrm{NO}^{\circ}$ from $S$-nitrosothiols via cleavage of the S-N bond. ${ }^{3,6-9}$ Several biological iron centers have been implicated in RSNO decomposition/formation. For example, heme-iron proteins, such as cytochrome $c$, are responsible for the coupling of NO and low-mass thiols to RSNOs, i.e., $S$-nitrosoglutathione (GSNO) or $S$-nitroso- $L$-cysteine (CysSNO). ${ }^{4}$ In addition to enzymatic heme-iron centers, exposure of $\mathrm{NO}^{\circ}$ to intracellular labile iron has been associated with increased levels of protein $S$ nitrosation with simultaneous formation of dinitrosyl iron complexes (DNICs). ${ }^{10,11}$ Moreover, the release of $\mathrm{NO}^{\circ}$ from the blood pressure medication sodium nitroprusside (SNP) $[\mathrm{Na}]_{2}\left[\mathrm{Fe}(\mathrm{CN})_{5}(\mathrm{NO})\right]$ is thought to proceed through the decomposition of an iron(II) $S$-nitrosothiol adduct, $\left[\mathrm{Fe}(\mathrm{CN})_{5}\left(\kappa^{1}-\mathrm{N}\right.\right.$ RSNO) $]^{3-}$, known as the "red product". ${ }^{12,13}$
Despite the importance of iron centers in facilitating the formation/decomposition of $S$-nitrosothiols, the discrete molecular mechanisms of N-S bond formation/cleavage at iron sites remain controversial. For example, two mechanisms have been proposed for $S$-nitrosothiol formation at heme-iron sites. The first involves nucleophilic attack of an iron nitrosyl $\{\mathrm{FeNO}\}^{6}$ species by a thiolate (Scheme 1, top), whereas the second invokes an $\mathrm{Fe}^{\mathrm{III}}$-thiolate intermediate undergoing further reaction with free NO* (Scheme 1, bottom). ${ }^{14,15}$ Despite the structural characterization of $S$-nitrosated heme-iron proteins, ${ }^{16}$ spectroscopic support for both mechanisms exists. ${ }^{16-18}$

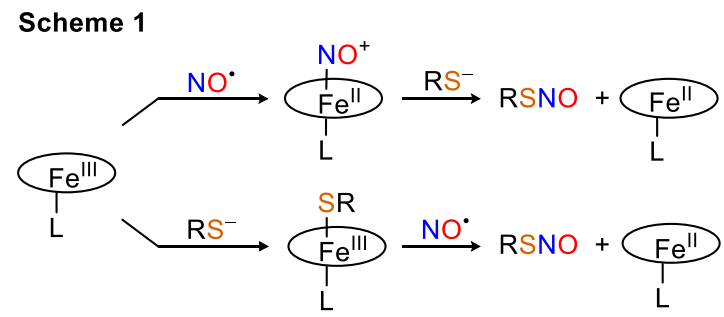

Significant research efforts have also been devoted to understanding the binding mode of $S$-nitrosothiols to Fe centers $\left(\kappa^{1}-\right.$ $\mathrm{N}$ vs. $\kappa^{1}-\mathrm{S}$ ) during NO ${ }^{*}$ release from SNP (Scheme 2 ). Spectroscopic studies suggest that the "red-product" $\left[\mathrm{Fe}(\mathrm{CN})_{5}\left(\kappa^{1}-\mathrm{N}\right.\right.$ RSNO) $]^{3-}$ extrudes a thiyl $\left(\mathrm{RS}^{\circ}\right)$ radical to form a $\left[(\mathrm{CN})_{5} \mathrm{FeNO}\right]^{3-}$ complex $\left(\{\mathrm{FeNO}\}^{7}\right)$ which then releases free NO.$^{19,20}$ However, both experimental ${ }^{8,21,22}$ and computational $^{23,24}$ studies have demonstrated the thiyl radical (RS') expulsion process in Scheme 2 should be unfavorable since $\kappa^{1}-\mathrm{N}$ coordination of $S$-nitrosothiols strengthens the $\mathrm{S}-\mathrm{N}$ bond (Scheme 3). Furthermore, the currently proposed mechanism does not explain the rapid vasodilatory effect of SNP, given the slow rate of $\mathrm{NO}^{\cdot}$ liberation from the $\{\mathrm{FeNO}\}^{7}\left[(\mathrm{CN})_{5} \mathrm{FeNO}\right]^{3-}$ $\left(\mathrm{k}=5.0 \times 10^{-5} \mathrm{~s}^{-1}\right.$, Scheme 2$) .{ }^{25}$ 


\section{Scheme 2}

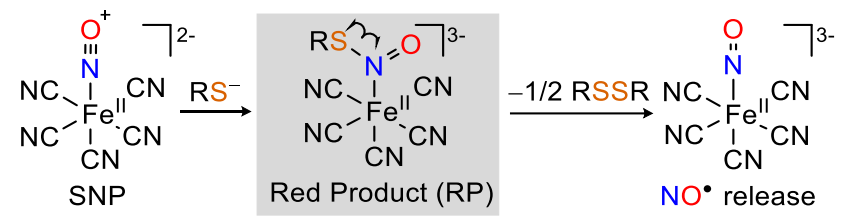

Too slow to explain the fast vasodilatory effect of SNP

As the debate for the mechanisms of $S$-nitrosothiol formation and decomposition at iron sites continue, the mechanism of RSNO formation mediated by the labile iron pool (LIP) also remains ambiguous. Iron within the LIP is present in both $\mathrm{Fe}^{\mathrm{II}} / \mathrm{Fe}^{\mathrm{III}}$ oxidation states and can be coordinated by various weak field ligands to form high-spin $\mathrm{Fe}^{\mathrm{II}} / \mathrm{Fe}^{\mathrm{III}}$ complexes. ${ }^{10,26-29}$ While Kim and Lippard have investigated the reactivity of NO* with synthetic iron-sulfur clusters ${ }^{30-33}$ and iron(II) thiolates, ${ }^{34-37}$ other simple $\mathrm{Fe}^{\mathrm{II}} / \mathrm{Fe}^{\mathrm{III}}$ coordination complexes relevant to the LIP and NO/S-nitrosothiol interconversion still warrant continued investigation.

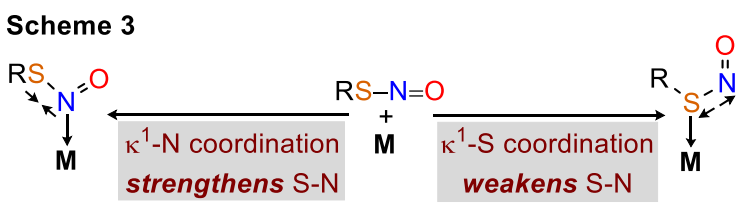

Herein, we employ $\mathrm{Fe}^{\mathrm{II}} / \mathrm{Fe}^{\mathrm{III}}$ chloride complexes as simplified models for LIP to investigate the potential roles of $\mathrm{Fe}^{\mathrm{II}} / \mathrm{Fe}^{\mathrm{III}}$ in RSNO formation/decomposition. We demonstrate that reaction of RSNO with $\mathrm{Fe}^{\mathrm{II}}$ chloride complexes leads to the facile release of NO from RSNO (Scheme 4). Spectroscopic studies suggest that the $\mathrm{Fe}^{\mathrm{II}}$ center interacts with the $\mathrm{S}$-atom before its conversion to iron(III)-halothiolate and $\mathrm{NO}^{\circ}$. The $\mathrm{NO}^{\circ}$ release from RSNO is reversible, and in the presence of an additional equivalent of $\mathrm{NO}^{*}$, the iron(III)-halothiolate captures $\mathrm{NO}^{*}$ to afford RSNO. The $\mathrm{Fe}^{\mathrm{II}}$ chloride by-product is trapped by a second equivalent of $\mathrm{NO}^{*}$ to form stable $\{\mathrm{FeNO}\}^{7}$ complexes that are inert toward catalytic decomposition of RSNO. This unique property of high-spin iron complexes may be a strategy Nature employs to reversibly regulate the bio-availability of free nitric oxide.

\section{Scheme 4}

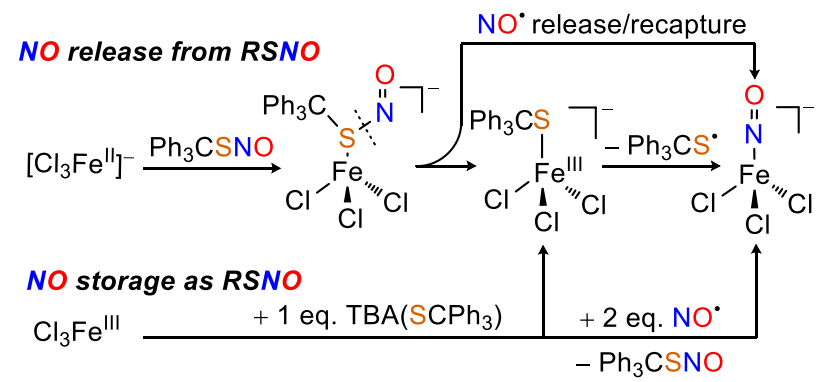

\section{RESULTS AND DISCUSSION}

Reactivity of $\mathrm{Fe}^{\mathrm{II}}$ chloride with $\boldsymbol{S}$-nitrosothiols. We began our investigation by preparing an iron(II) halide complex soluble in aprotic solvents. Treatment of PPNCl (PPN = bis(triphenylphosphine)iminium) with $\mathrm{Fe}^{\mathrm{II}} \mathrm{Cl}_{2}$ in acetone affords $\mathrm{PPN}_{2}\left[\mathrm{Fe}^{\mathrm{II}}{ }_{2} \mathrm{Cl}_{6}\right]$. The spectroscopic characterizations of the $\mathrm{PPN}_{2}\left[\mathrm{Fe}^{\mathrm{II}}{ }_{2} \mathrm{Cl}_{6}\right]$ complex match those reported in the literature. ${ }^{38}$ The analogous TBA salt of iron(II) trichloride was isolated as colorless crystals by the addition of $\mathrm{TBACl}$ (TBA $=$ tetrabutylammonium) to $\mathrm{Fe}^{\mathrm{II}} \mathrm{Cl}_{2}$. Single-crystal X-ray diffraction analysis indicates that the $\mathrm{Fe}^{\mathrm{II}}$ centers exist in two types of coordination environments, as $\left[\mathrm{Fe}^{\mathrm{II}_{2}} \mathrm{Cl}_{6}\right]^{2-}$ and monomeric $\left[\mathrm{Cl}_{3} \mathrm{Fe}^{\mathrm{II}}\left(\mathrm{H}_{2} \mathrm{O}\right)\right]^{-}$(Figure S26). Next, we monitored the reaction of $\left[\mathrm{Fe}^{\mathrm{II}}{ }_{2} \mathrm{Cl}_{6}\right]^{2-}$ with $\mathrm{Ph}_{3} \mathrm{CSNO}$ with $\mathrm{UV}$-vis spectroscopy at low temperature. The structural difference between the PPN and TBA salts of the $\mathrm{Fe}^{\mathrm{II}}$ chlorides in the solid-state does not impact their reactivity with $S$-nitrosothiols (Figures S7, S8). Addition of two equivalents of $\mathrm{Ph}_{3} \mathrm{CSNO}$ to $\left[\mathrm{Fe}^{\mathrm{II}}{ }_{2} \mathrm{Cl}_{6}\right]^{2-}$ in a $1: 1$ mixture of $\mathrm{THF}$ and $\mathrm{MeCN}$ at $-50{ }^{\circ} \mathrm{C}$ affords a dark brown complex with UV-vis absorption bands at $520 \mathrm{~nm}\left(\varepsilon=1000 \mathrm{M}^{-1} \mathrm{~cm}^{-1}\right)$ and $630 \mathrm{~nm}\left(\varepsilon=970 \mathrm{M}^{-1} \mathrm{~cm}^{-1}\right)$ (Figure 1, brown trace), which slowly converts to a green species at room temperature with absorbances at $365 \mathrm{~nm}\left(\varepsilon=1080 \mathrm{M}^{-1} \mathrm{~cm}^{-1}\right), 480 \mathrm{~nm}\left(\varepsilon=410 \mathrm{M}^{-1}\right.$ $\left.\mathrm{cm}^{-1}\right)$, and $660 \mathrm{~nm}\left(\varepsilon=320 \mathrm{M}^{-1} \mathrm{~cm}^{-1}\right)$ (Figure 1, green trace). The final green complex was identified as $S=3 / 2$ $\mathrm{TBA}\left[\mathrm{Cl}_{3} \mathrm{FeNO}\right]$, which can be independently synthesized by treatment of $\left[\mathrm{Fe}^{\mathrm{II}}{ }_{2} \mathrm{Cl}_{6}\right]^{2-}$ with $\mathrm{NO}^{*}$ (Figure S4). ${ }^{39}$ Based on the absorptivity of $\left[\mathrm{Cl}_{3} \mathrm{FeNO}\right]^{-}$, the yield of $\mathrm{TBA}\left[\mathrm{Cl}_{3} \mathrm{FeNO}\right]$ was approximately quantitative. The $\left[\mathrm{Cl}_{3} \mathrm{FeNO}\right]^{-}$anion was observed first by Kohlschütter, ${ }^{40}$ and structurally characterized by Van Eldik ${ }^{41}$, Beck, ${ }^{42}$ and Klüfers. ${ }^{39}$ The $S=3 / 2$ spin state of $\left[\mathrm{Cl}_{3} \mathrm{FeNO}\right]^{-}$was established recently based on SQUID measurement $^{39}$ and our Evans method study (see supporting information). The $\left[\mathrm{Cl}_{3} \mathrm{FeNO}\right]^{-}$complex is remarkably stable to oxygen and moisture, and no decomposition of $\mathrm{PPN}\left[\mathrm{Cl}_{3} \mathrm{FeNO}\right]$ solid was observed even after storage under ambient conditions for several days.
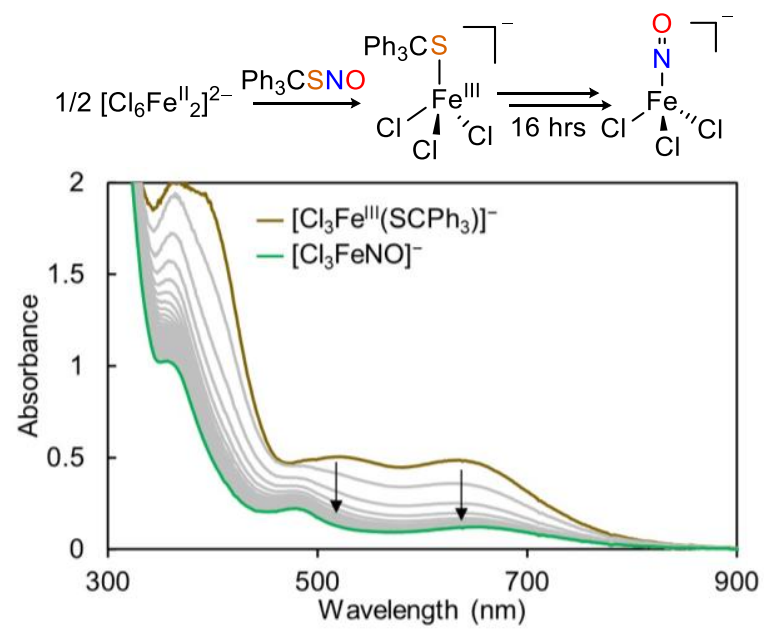

Figure 1. In situ UV-vis spectra of the treatment of $\left[\mathrm{Fe}_{2} \mathrm{Cl}_{6}\right]^{2-}$ with two equivalents of $\mathrm{Ph}_{3} \mathrm{CSNO}$ at $-50{ }^{\circ} \mathrm{C}$ in $1: 1 \mathrm{THF} / \mathrm{CH}_{3} \mathrm{CN}(0.5 \mathrm{mM})$. The brown intermediate $\left[\mathrm{Cl}_{3} \mathrm{Fe}\left(\mathrm{SCPh}_{3}\right)\right]^{-}$was eventually converted to $\left[\mathrm{Cl}_{3} \mathrm{FeNO}\right]^{-}$(green trace).

Two possible mechanisms could explain the formation of $\left[\mathrm{Cl}_{3} \mathrm{FeNO}\right]^{-}$(Scheme 5). Based on the proposed mechanism of $\mathrm{NO}^{\bullet}$ release from SNP (Scheme 2), one could envision coordination of $\mathrm{Ph}_{3} \mathrm{CSNO}$ to the $\mathrm{Fe}^{\mathrm{II}}$ center to form a Fe ${ }^{\mathrm{II}} \kappa^{1}-\mathrm{N} S$-nitrosothiol adduct, followed by thiyl radical extrusion to afford $\left[\mathrm{Cl}_{3} \mathrm{FeNO}\right]^{-}$(Mechanism A, Scheme 5 top). However, Mechanism A contradicts the chemical reactivity of metal $S$-nitrosothiols described in Scheme 3.,21,22 Therefore, an alternative mechanism in which the $\mathrm{Fe}^{\mathrm{II}}$ center interacts with the $\mathrm{S}$-atom warrants consideration (Mechanism B, Scheme 5 bottom). In this case, $\mathrm{NO}^{*}$ is released from $\left[\mathrm{Cl}_{3} \mathrm{Fe}\left(\kappa^{1}-\mathrm{S}-\mathrm{Ph}_{3} \mathrm{CSNO}\right)\right]^{-}$then recaptured by $\left[\mathrm{Fe}_{2}{ }_{2} \mathrm{Cl}_{6}\right]^{2-}$ generated from the decomposition of 
$\left[\mathrm{Cl}_{3} \mathrm{Fe}^{\mathrm{III}}-\mathrm{SCPh}_{3}\right]^{-}$. The key difference between these two mechanisms is the identity of the brown intermediate prior to the formation of $\left[\mathrm{Cl}_{3} \mathrm{FeNO}\right]^{-}$(highlighted in gray, Scheme 5). In Mechanism A, the brown intermediate should be $\left[\mathrm{Cl}_{3} \mathrm{Fe}\left(\kappa^{1}-\mathrm{N}\right.\right.$ $\left.\left.\mathrm{Ph}_{3} \mathrm{CSNO}\right)\right]^{-}$, while for Mechanism $\mathrm{B}$ it should be either $\left[\mathrm{Cl}_{3} \mathrm{Fe}\left(\kappa^{1}-\mathrm{S}-\mathrm{Ph}_{3} \mathrm{CSNO}\right)\right]^{-}$or $\left[\mathrm{Cl}_{3} \mathrm{Fe}^{\mathrm{III}}-\mathrm{SCPh}_{3}\right]^{-}$.

Scheme 5
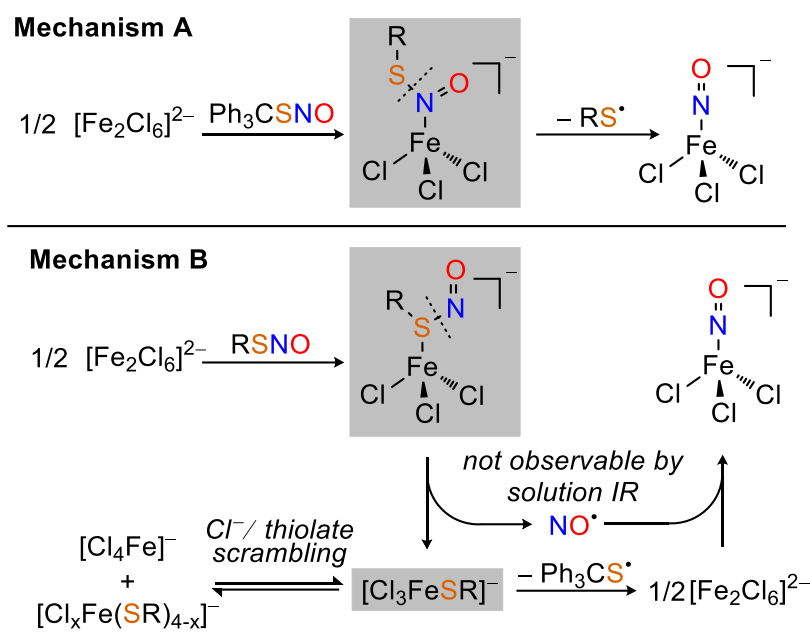

Characterization of the $\mathrm{Fe}^{\mathrm{III}}$ halothiolate intermediate. To further discern the two proposed mechanisms, we set out to identify the initial brown intermediate that absorbs at $520 \mathrm{~nm}$ and $630 \mathrm{~nm}$. Anticipating it might be the iron(III)-halothiolate $\left[\mathrm{Cl}_{3} \mathrm{Fe}^{\mathrm{III}}-\mathrm{SCPh}_{3}\right]^{-}$, we attempted to generate it from an independent reaction between $\mathrm{TBA}\left[\mathrm{Cl}_{4} \mathrm{Fe}^{\mathrm{III}}\right]$ and $\mathrm{NaSCPh}_{3}$. As shown in Figure 2, the in situ UV-vis spectrum of the reaction of $\mathrm{TBA}\left[\mathrm{Cl}_{4} \mathrm{Fe}^{\mathrm{III}}\right]$ with one equivalent of $\mathrm{NaSCPh}_{3}$ in $\mathrm{MeCN} / \mathrm{THF}$ (red trace) shows a good match with the brown intermediate. Further, the reaction between $\mathrm{FeCl}_{3}$ and $\mathrm{TBA}\left(\mathrm{SCPh}_{3}\right)$ leads to the formation of the same spectrum, albeit at a lower spectroscopic yield (Figure S10). In addition, the predicted $\mathrm{UV}$-vis spectrum of $\left[\mathrm{Cl}_{3} \mathrm{Fe}^{\mathrm{III}}-\mathrm{SCPh}_{3}\right]^{-}$by time-dependent density functional theory (TD-DFT) at the TPSSh/def2-TZVP level correlates well with the experimental data (Figure S26). Unfortunately, we were unable to structur-

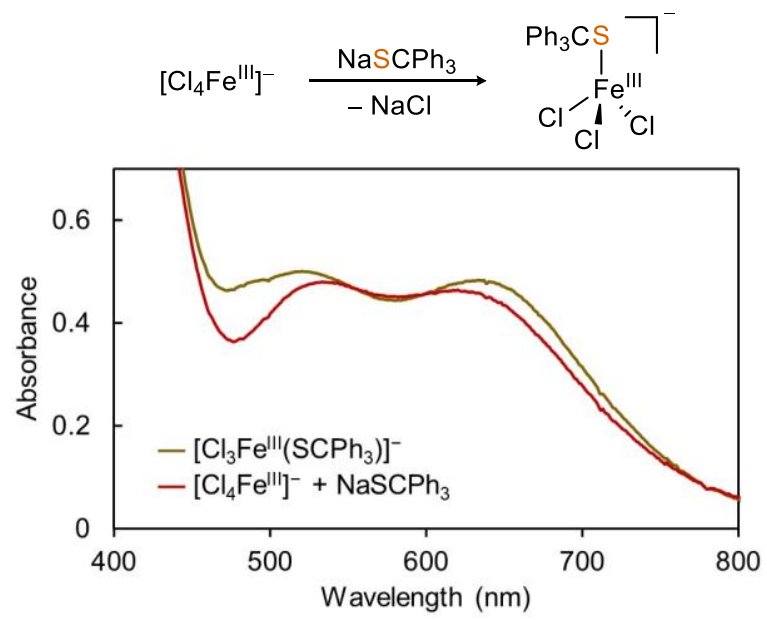

Figure 2. Comparison of initial UV-vis spectra resulting from the reaction between $\left[\mathrm{Fe}_{2} \mathrm{Cl}_{6}\right]^{2-}$ and $\mathrm{Ph}_{3} \mathrm{CSNO}$ at $-50{ }^{\circ} \mathrm{C}$ in $1: 1 \mathrm{THF} / \mathrm{CH}_{3} \mathrm{CN}$ (0.5 mM, brown trace); the reaction between $\mathrm{TBA}\left[\mathrm{Cl}_{4} \mathrm{Fe}^{\mathrm{III}}\right]$ and one equivalent of $\mathrm{NaSCPh}_{3}$ at $-20^{\circ} \mathrm{C}(0.5 \mathrm{mM}$, red trace $)$.

ally characterize the putative $\left[\mathrm{Cl}_{3} \mathrm{Fe}^{\mathrm{III}}-\mathrm{SCPh}_{3}\right]^{-}$due to complicated ligand scrambling that generates other $\left[\mathrm{Cl}_{\mathrm{x}} \mathrm{Fe}^{\mathrm{III}}\right.$ $\left.\left(\mathrm{SCPh}_{3}\right)_{4^{-} \mathrm{x}}\right]^{-}(\mathrm{x}=1,2,3,4)$ as well as decomposition of $\left[\mathrm{Cl}_{3} \mathrm{Fe}^{\mathrm{III}}-\mathrm{SCPh}_{3}\right]^{-}$to $\mathrm{Ph}_{3} \mathrm{CS}-\mathrm{SCPh}_{3}$ and $\left[\mathrm{Fe}_{2}{ }_{2} \mathrm{Cl}_{6}\right]^{2-}$ (see supporting information). Titration experiments of $\mathrm{NaSCPh}_{3}$ into $\mathrm{TBA}\left[\mathrm{Cl}_{4} \mathrm{Fe}^{\mathrm{III}}\right]$, and $\mathrm{TBA}\left(\mathrm{SCPh}_{3}\right)$ into $\mathrm{FeCl}_{3}$ at $-40{ }^{\circ} \mathrm{C}$ show formation of multiple species from a $1: 1$ to $4: 1$ thiolate to $\mathrm{Fe}^{\mathrm{III}}$ ratio (Figures S11, S12). Regardless of molecular connectivity, the ratio of $\mathrm{Cl}^{-}: \mathrm{Fe}^{\mathrm{III}}: \mathrm{Ph}_{3} \mathrm{CS}^{-}$remains as 3:1:1 under the experimental conditions employed; therefore, we will refer to the collective products of $\mathrm{Cl}_{3} \mathrm{Fe}^{\mathrm{III}}$ and $\mathrm{Ph}_{3} \mathrm{CS}^{-}$as $\left[\mathrm{Cl}_{3} \mathrm{Fe}^{\mathrm{III}}-\mathrm{SCPh}_{3}\right]^{-}$for simplicity.

Analysis of the brown intermediate with Mössbauer spectroscopy further supports its assignment as an $\mathrm{Fe}^{\mathrm{III}}$ thiolate species. Independent generation of $\left[\mathrm{Cl}_{3}{ }^{57} \mathrm{Fe}^{\mathrm{III}}\left(\mathrm{SCPh}_{3}\right)\right]^{-}$from the reaction between $\mathrm{TBA}\left[\mathrm{Cl}_{4}{ }^{57} \mathrm{Fe}^{\mathrm{III}}\right]$ and one equivalent of $\mathrm{NaSCPh}_{3}$ displays a Mössbauer spectrum similar to that produced from the reaction between $\mathrm{TBA}_{2}\left[\mathrm{Cl}_{6}{ }^{57} \mathrm{Fe}_{2}^{\mathrm{II}}\right]$ and two equivalents of $\mathrm{Ph}_{3} \mathrm{CSNO}$ (See supporting information, Figures S18, S19). Both spectra display peaks corresponding to two major species-the first one ( $\mathrm{ca} .40 \%$ ) exhibiting isomer shift and quadrupole splitting values identical to that of $\mathrm{TBA}_{2}\left[\mathrm{Cl}_{6}{ }^{57} \mathrm{Fe}^{\mathrm{II}}{ }_{2}\right](\delta=$ $1.16 \mathrm{~mm} \mathrm{~s}^{-1},\left|\Delta E_{Q}\right|=2.86 \mathrm{~mm} \mathrm{~s}^{-1}$ (Figure S14)). The second component (ca. 60\%) displays an isomer shift of $\delta=0.38 \mathrm{~mm}$ $\mathrm{s}^{-1}$ and quadrupole splitting value of $\left|\Delta E_{Q}\right|=0.94 \mathrm{~mm} \mathrm{~s}^{-1}$, which was assigned as $\left[\mathrm{Cl}_{3} \mathrm{Fe}^{\mathrm{III}}\left(\mathrm{SCPh}_{3}\right)\right]^{-}$. These parameters are different from those of TBA $\left[\mathrm{Cl}_{4}{ }^{57} \mathrm{Fe}^{\mathrm{III}}\right]$ (Figure S17), which has an isomer shift value of $\delta=0.23 \mathrm{~mm} \mathrm{~s}^{-1}$ and a quadrupole splitting of $\left|\Delta E_{Q}\right|=0.53 \mathrm{~mm} \mathrm{~s}^{-1}$ (Table 1).

Table 1. Solution Mössbauer parameters

\begin{tabular}{c|cc}
\hline Complex (major component) & $\delta(\mathrm{mm} / \mathrm{s})$ & $\Delta E_{Q}(\mathrm{~mm} / \mathrm{s})$ \\
\hline $\mathrm{TBA}_{2}\left[\mathrm{Cl}_{6}{ }^{57} \mathrm{Fe}^{\mathrm{II}}{ }_{2}\right]$ & 1.16 & 2.86 \\
$\mathrm{TBA}\left[\mathrm{Cl}_{4}{ }^{57} \mathrm{Fe}^{\mathrm{III}}\right]$ & 0.23 & 0.53 \\
$\mathrm{TBA}\left[\mathrm{Cl}_{4}{ }^{57} \mathrm{Fe}^{\mathrm{III}}\right]+\mathrm{NaSCPh}_{3}$ & 0.38 & 0.94 \\
$\mathrm{TBA}_{2}\left[\mathrm{Cl}_{6}{ }^{57} \mathrm{Fe}^{\mathrm{II}}{ }_{2}\right]+2 \mathrm{Ph}_{3} \mathrm{CSNO}$ & 0.38 & 0.93 \\
\hline
\end{tabular}

In situ IR study of the conversion of $\left[\mathrm{Fe}^{\mathrm{II}}{ }_{2} \mathrm{Cl}_{6}\right]^{2-}$ to $\left[\mathrm{Cl}_{3} \mathrm{FeNO}\right]^{-}$by $\mathrm{Ph}_{3} \mathrm{CSNO}$. The in situ UV-vis and Mössbauer data so far suggest that reaction of $\left[\mathrm{Fe}_{2}{ }_{2} \mathrm{Cl}_{6}\right]^{2-}$ with $\mathrm{Ph}_{3} \mathrm{CSNO}$ first leads to the formation of an iron(III) halothiolate and free NO*. The iron(III) halothiolate then slowly decomposes to disulfide and $\left[\mathrm{Fe}_{2}{ }_{2} \mathrm{Cl}_{6}\right]^{2-}$, which captures free $\mathrm{NO}$ to form the $\left[\mathrm{Cl}_{3} \mathrm{FeNO}\right]^{-}$complex (Scheme 5, Mechanism B). Further support of Mechanism B was provided by an in situ time-resolved solution IR study. Addition of $\left[\mathrm{Fe}^{\mathrm{II}}{ }_{2} \mathrm{Cl}_{6}\right]^{2-}$ to a solution with two equivalents of $\mathrm{Ph}_{3} \mathrm{CSNO}$ in THF- $d_{8}$ at $-70{ }^{\circ} \mathrm{C}$ results in a decrease of the peak at $1493 \mathrm{~cm}^{-1}$ corresponding to $\mathrm{Ph}_{3} \mathrm{CSNO}$. Upon further warming of the reaction mixture to $-50{ }^{\circ} \mathrm{C}$, a new band at $1792 \mathrm{~cm}^{-1}$ appeared, which was attributed to TBA[Cl $\mathrm{Cl}_{3} \mathrm{FeNO}$ ] (Figure 3A). ${ }^{39}$ An ${ }^{15} \mathrm{~N}$-labeling experiment confirmed that $\mathrm{Ph}_{3} \mathrm{CSNO}$ and $\left[\mathrm{Cl}_{3} \mathrm{FeNO}\right]^{-}$were the only species observed with ${ }^{15} \mathrm{~N}$-sensitive stretches over the course of the reaction (See SI, Figure S21, S22). Importantly, the initial decay of $\mathrm{Ph}_{3} \mathrm{CSNO}$ was not accompanied by the formation of $\left[\mathrm{Cl}_{3} \mathrm{FeNO}\right]^{-}$(Figure 3B). The time gap ( $\mathrm{ca} .90$ seconds) between these two events provides further assent that free $\mathrm{NO}^{\circ}$ was first released into the headspace, where it was unobservable by solution IR until it was recaptured by $\left[\mathrm{Fe}_{2}{ }_{2} \mathrm{Cl}_{6}\right]^{2-}$ as $\left[\mathrm{Cl}_{3} \mathrm{FeNO}\right]^{-}$, consistent with Mechanism B (Scheme 5, bottom). 


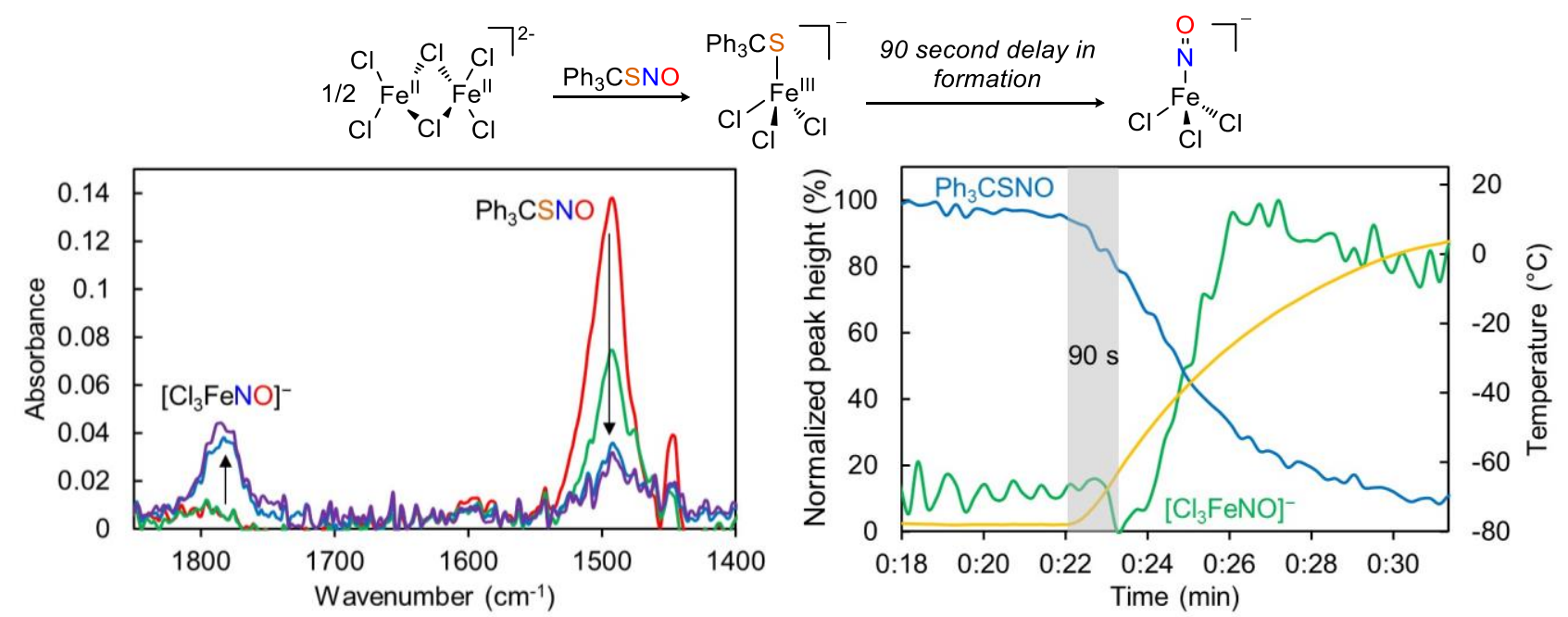

Figure 3. Left: A) In situ solution IR spectra of the reaction between $\left[\mathrm{Fe}_{2} \mathrm{Cl}_{6}\right]^{2-}$ and $\mathrm{Ph}_{3} \mathrm{CSNO}$ in THF- $d_{8}, 30 \mathrm{mM}$ (from red to purple traces), showing a decrease in $v(\mathrm{NO})=1493 \mathrm{~cm}^{-1}\left(\mathrm{Ph}_{3} \mathrm{CSNO}\right)$ and the appearance of $v(\mathrm{NO})=1792 \mathrm{~cm}^{-1}\left(\left[\mathrm{Cl}_{3} \mathrm{FeNO}\right]^{-}\right)$upon warming. B) Normalized peak heights of $\mathrm{Ph}_{3} \mathrm{CSNO}$ (blue) and $\mathrm{TBA}\left[\mathrm{Cl}_{3} \mathrm{FeNO}\right]$ (green) versus time and temperature (yellow) shows a 90 second delay (shaded grey) in $\mathrm{TBA}\left[\mathrm{Cl}{ }_{3} \mathrm{FeNO}\right]$ formation.

In situ UV-vis, Mössbauer, and IR spectroscopic studies allow us to conclude that $\mathrm{NO}^{\bullet}$ release likely proceeds through coordination of the $\mathrm{S}$-atom to $\mathrm{Fe}^{\mathrm{II}}$ prior to $\mathrm{S}-\mathrm{N}$ bond cleavage. Otherwise, the concurrent formation of $\left[\mathrm{Cl}_{3} \mathrm{FeNO}\right]^{-}$and consumption of $\mathrm{Ph}_{3} \mathrm{CSNO}$ would be expected. The proposed mechanism is also consistent with the reactivity profile of metal $S$ nitrosothiol complexes $-\kappa^{1}-\mathrm{S}$ coordination weakens the S-N bond, making the release of $\mathrm{NO}^{*}$ more favorable (Scheme 3$){ }^{13}$

RSNO formation from putative iron(III) halothiolate As many $\mathrm{NO}^{*}$ release/storage mechanisms are reversible in $\mathrm{Na}-$ ture, ${ }^{8}$ we next investigated whether the $\mathrm{Fe}^{\mathrm{II}} / \mathrm{Fe}^{\mathrm{III}}$ chloride couple can carry out the formation of $S$-nitrosothiol. Lancaster et al. proposed that the LIP can promote RS-NO bond formation based on the observation that the cellular protein $S$-nitrosation levels strongly depend on the concentration of labile/chelatable iron. $^{10,11}$ To this end, we first generated the putative $\left[\mathrm{Cl}_{3} \mathrm{Fe}^{\mathrm{III}} \mathrm{SCPh}_{3}\right]^{-}$by treating $\mathrm{Fe}^{\mathrm{III}} \mathrm{Cl}_{3}$ with $\mathrm{TBA}\left(\mathrm{SCPh}_{3}\right)$ at -78 ${ }^{\circ} \mathrm{C}$ and subjected this reaction mixture to sequential additions of NO*. In situ solution IR spectroscopy was utilized to monitor and quantify product formation. After the addition of two equivalents of $\mathrm{NO}^{\circ}$ at $-78{ }^{\circ} \mathrm{C}$ and upon warming the reaction
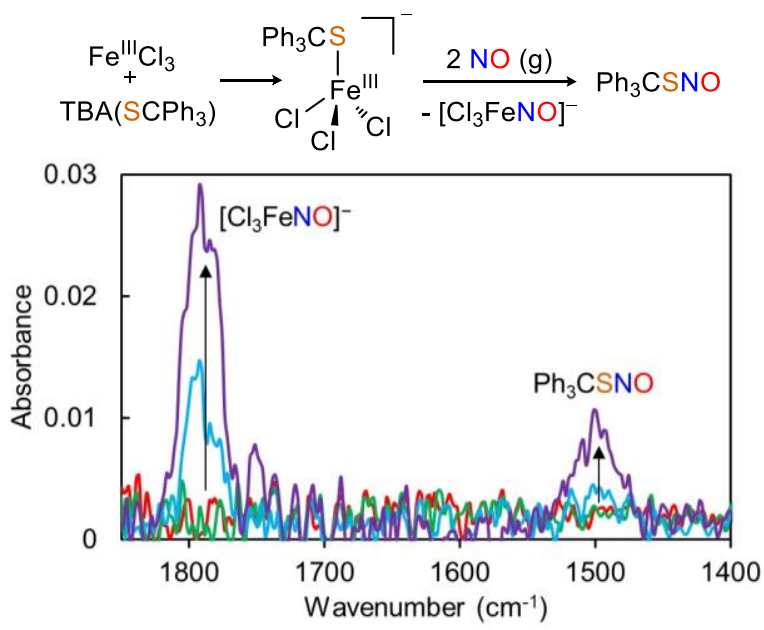

Figure 4. In situ IR spectrum of the reaction between $\left[\mathrm{Cl}_{3} \mathrm{Fe}^{\mathrm{III}} \mathrm{SCPh}_{3}\right]^{-}$ and 2 eq NO in 9:1 THF- $d_{8} / \mathrm{CD}_{3} \mathrm{CN}$ at $-80{ }^{\circ} \mathrm{C}(30 \mathrm{mM})$. At $-50{ }^{\circ} \mathrm{C}$ formation of $\mathrm{Ph}_{3} \mathrm{CSNO}\left(v(\mathrm{NO})=1493 \mathrm{~cm}^{-1}\right)$ and $\mathrm{TBA}\left[\mathrm{Cl}_{3} \mathrm{FeNO}\right]$ $\left(v(\mathrm{NO})=1792 \mathrm{~cm}^{-1}\right)$ was observed. mixture to $-50{ }^{\circ} \mathrm{C}$, we observed concurrent formation of peaks at $1792 \mathrm{~cm}^{-1}$ and $1493 \mathrm{~cm}^{-1}$ (Figure. 2C), assigned as $\left[\mathrm{Cl}_{3} \mathrm{FeNO}\right]^{-}$and $\mathrm{Ph}_{3} \mathrm{CSNO}$, respectively. ${ }^{39,45}$ The estimated yields of $\left[\mathrm{Cl}_{3} \mathrm{FeNO}\right]^{-}$and $\mathrm{Ph}_{3} \mathrm{CSNO}$ were $67 \%$ and $50 \%$, respectively, based on the IR absorbances (see supporting information, Figures S24, S25). The Fe $\mathrm{FII}^{\mathrm{III}}$ center facilitates the oxidative coupling of thiolate and $\mathrm{NO}^{*}$ to form $\mathrm{Ph}_{3} \mathrm{CSNO}$ by acting as an electron acceptor and undergoing reduction to $\mathrm{Fe}^{\mathrm{II}}$, which may be trapped by additional $\mathrm{NO}^{*}$ to form $\left[\mathrm{Cl}_{3} \mathrm{FeNO}\right]^{-}$. The presence of an additional equivalent of $\mathrm{NO}^{*}$ is critical to prevent the reverse reaction, that is, the release of $\mathrm{NO}^{*}$ from $\mathrm{Ph}_{3} \mathrm{CSNO}$, as $\mathrm{Fe}^{\mathrm{II}}$ complexes are known to lead to the decomposition of RSNO to disulfide and NO` (Scheme 6). The robust Fe-NO interaction impedes the displacement of the NO ligand by $S$-nitrosothiol and prevents the catalytic decomposition of RSNO (Scheme 6). Such a "switch effect" of NO" represents a key difference between $\mathrm{Fe}$ and $\mathrm{Cu}$ mediated $S$-nitrosothiol formation; the strong interaction between high-spin $\mathrm{Fe}^{\mathrm{III}}(\mathrm{S}=5 / 2)$ with $\mathrm{NO}^{-}(\mathrm{S}=1)$ is not shared by $\mathrm{Cu}^{6}$ In fact, some of us, and Hayton et al. have shown that the interaction of $\mathrm{Cu}^{\mathrm{II}}$ and $\mathrm{NO}^{-}$is highly reversible. ${ }^{46,47}$

\section{Scheme 6}

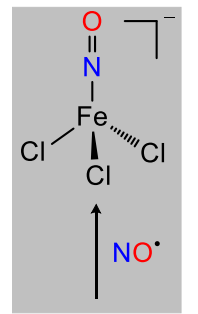

Switch effect of NO' allows RSNO release from $\mathrm{Fe}^{\prime \prime}$

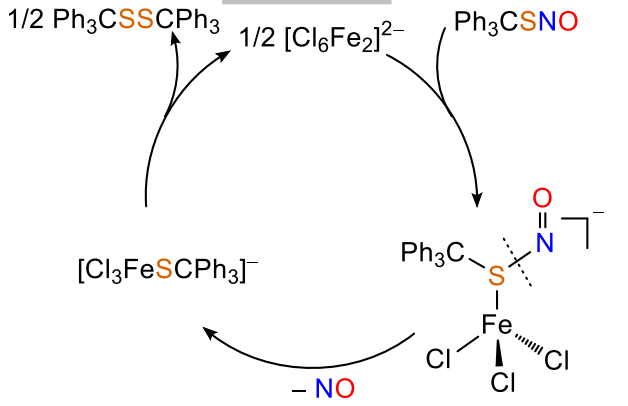


To confirm that $\left[\mathrm{Cl}_{3} \mathrm{FeNO}\right]^{-}$does not participate in RS-NO bond formation, we investigated its reaction with thiolate. Treatment of PPN $\left[\mathrm{Cl}_{3} \mathrm{FeNO}\right]$ with sodium tert-butyl thiolate affords a red-colored solution with strong absorbances at $360 \mathrm{~nm}$ $\left(\varepsilon=6670 \mathrm{M}^{-1} \mathrm{~cm}^{-1}\right)$ and $475 \mathrm{~nm}\left(\varepsilon=4360 \mathrm{M}^{-1} \mathrm{~cm}^{-1}\right)$, which were assigned as PPN $\left[\left({ }^{t} \mathrm{BuS}\right)_{3} \mathrm{FeNO}\right] .{ }^{36}$ Titration of tert-butyl thiolate to a solution of $\mathrm{PPN}\left[\mathrm{Cl}_{3} \mathrm{FeNO}\right]$ in $\mathrm{UV}$-vis spectrometer confirmed the 3:1 stoichiometry (Figure S6). Employing tertbutyl thiolate allowed us to calculate the yield of the product $\left[\left({ }^{t} \mathrm{BuS}\right)_{3} \mathrm{FeNO}\right]^{-}$based on reported molar extinction coefficients. The spectroscopic yield of $\left[\left({ }^{t} \mathrm{BuS}\right)_{3} \mathrm{FeNO}\right]^{-}$was determined to be $99 \%$, indicating that the $\{\mathrm{FeNO}\}^{7}$ motif is robust, while $\mathrm{Cl}^{-}$ligand exchange occurs with ${ }^{t} \mathrm{BuS}^{-36}$

Scheme 7

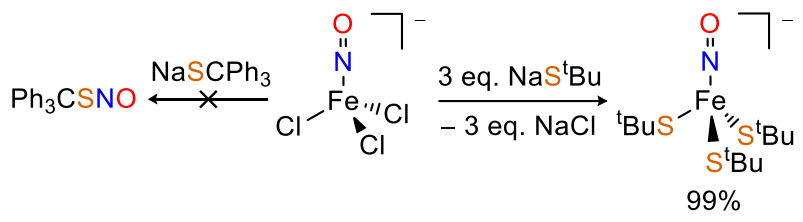

Electronic structure of $\left[\mathrm{Cl}_{3} \mathrm{FeNO}\right]^{-},\left[\mathrm{Cl}_{3} \mathrm{CuNO}\right]^{-}$, and $\mathrm{Cl}_{3} \mathrm{FeNO}$ The inertness of $\left[\mathrm{Cl}_{3} \mathrm{FeNO}\right]^{-}$towards nitrosation of thiolate and the irreversible binding of $\mathrm{NO}^{*}$ at $\left[\mathrm{Cl}_{3} \mathrm{Fe}^{\mathrm{II}}\right]^{-}$is a crucial part of Mechanism B proposed in Scheme 5. These properties of $\left[\mathrm{Cl}_{3} \mathrm{FeNO}\right]^{-}$are in sharp contrast to its $\mathrm{Cu}$ analog $\left[\mathrm{Cl}_{3} \mathrm{CuNO}^{-}\right.$, which exhibits both reversible binding with $\mathrm{NO}^{\circ}$ and nitrosative reactivity toward thiolates. To gain more insight into the different reactivities of $\left[\mathrm{Cl}_{3} \mathrm{FeNO}\right]^{-}$and $\left[\mathrm{Cl}_{3} \mathrm{CuNO}\right]^{-}$, we utilized complete active space self-consistent field (CASSCF) computations to further understand their electronic structure. Some of us $^{46}$ and others ${ }^{39,46,48,49}$ have shown that CASSCF calculations can provide a detailed understanding of the correlation of electronic structure and reactivity of metalnitrosyls. The state-specific CASSCF calculations were performed in each complex's well-established spin state, $S=3 / 2$ for $\left[\mathrm{Cl}_{3} \mathrm{FeNO}\right]^{-}$and $S=0$ for $\left[\mathrm{Cl}_{3} \mathrm{CuNO}\right]^{-} \cdot{ }^{39,46,50}$ After screening various combinations of metal $3 \mathrm{~d}, \mathrm{NO}-\sigma^{*}$, and $\mathrm{NO}-\pi^{*}$ orbitals, we chose an active-space of $[9 \mathrm{e}, 13 \mathrm{o}]$ for $\left[\mathrm{Cl}_{3} \mathrm{FeNO}\right]^{-}$and $[10 \mathrm{e}, 13 \mathrm{o}]$ for $\left[\mathrm{Cl}_{3} \mathrm{CuNO}\right]^{-}$. These active spaces include (i) bonding and antibonding orbitals of NO- $\pi^{*}$ with metal- $\mathrm{d}_{\mathrm{xz} / \mathrm{yz}}$, (ii) bonding and antibonding orbitals of $\mathrm{NO}-\sigma^{*}$ with metal- $\mathrm{d}_{\mathrm{z} 2}$, (iii) nonbonding $\mathrm{d}_{\mathrm{x} 2-\mathrm{y} 2 / \mathrm{xy}}$ as well as (iv) the next five unoccupied orbitals lowest in energy, which are often based on metal $4 \mathrm{~d}$ or ancillary ligands $\mathrm{Cl}^{-}$(See supporting information)). We found that $4 \mathrm{~d}$ orbitals and ancillary orbitals have little effect on the results of the calculations, consistent with previous studies by Klüfers. ${ }^{39,49}$ To computationally estimate the amount of $\mathrm{NO}^{-/ \cdot /+}$ character in each complex, a valence bond-like interpretation of the CAS wavefunction was applied by following the method laid out by Radón et al. ${ }^{51}$ The amount of $\mathrm{NO}^{-/ /+}$character in each species is summarized in Table 2. Intuitively, higher percentages of $\mathrm{M}^{\mathrm{n}+1}-\mathrm{NO}^{+}$character correlates to $\mathrm{NO}^{+}$transfer (nitrosative) ability, while $\mathrm{M}^{\mathrm{n}}-\mathrm{NO}^{*}$ corresponds to free $\mathrm{NO}^{*}$ release. We found the CASSCF results to be roughly consistent with the observed reactivity of $\left[\mathrm{Cl}_{3} \mathrm{FeNO}\right]^{-}$and $\left[\mathrm{Cl}_{3} \mathrm{CuNO}\right]^{-}$. Specifically, $\left[\mathrm{Cl}_{3} \mathrm{FeNO}^{-}\right.$exhibits the lowest $\mathrm{NO}^{*}$ character $(38 \%)$ and $\mathrm{NO}^{+}$character $(2 \%)$, consistent with its inability to release free $\mathrm{NO}^{*}$ and perform $S$-nitrosation. $\left[\mathrm{Cl}_{3} \mathrm{CuNO}^{-}\right.$exhibits significant $\mathrm{NO}^{\circ}$ and $\mathrm{NO}^{+}$character $(86 \%$ and $10 \%$, respectively) and is capable of both $\mathrm{NO}^{\circ}$ release and $S$-nitrosation. ${ }^{46}$

Table 2. Results of valence-bond analysis of metal nitrosyls

\begin{tabular}{|c|c|c|c|}
\hline Res. Structure & {$\left[\mathrm{Cl}_{3} \mathrm{FeNO}\right]^{-}$} & {$\left[\mathrm{Cl}_{3} \mathrm{CuNO}\right]^{-}$} & $\mathrm{Cl}_{3} \mathrm{FeNO}$ \\
\hline$M-N O^{-}$ & $52 \%$ & $1 \%$ & $0.25 \%$ \\
\hline$M-N O^{\bullet}$ & $40 \%$ & $86 \%$ & $93 \%$ \\
\hline $\mathrm{M}-\mathrm{NO} \mathrm{O}^{+}$ & $2 \%$ & $10 \%$ & $4 \%$ \\
\hline others & $5 \%$ & $3 \%$ & $2 \%$ \\
\hline
\end{tabular}

We were curious as to whether this qualitative analysis would allow us to predict the $\mathrm{NO}^{+}$reactivity of $\mathrm{Cl}_{3} \mathrm{FeNO}$, the product of the one-electron oxidation of $\left[\mathrm{Cl}_{3} \mathrm{FeNO}\right]^{-}$. This theoretical interaction of $\mathrm{Fe}^{\mathrm{III}} \mathrm{Cl}_{3}$ with $\mathrm{NO}^{*}$ would result in an $\{\mathrm{FeNO}\}^{6}$ complex with a spin $(S=2)$, which would be more likely to exhibit $\mathrm{NO}^{+}$transferring ability. The geometry of putitive $\mathrm{Cl}_{3} \mathrm{FeNO}$ complex was optimized with DFT in a variety of spin states $(S=0,1,2)$. The two known non-heme $\{\mathrm{FeNO}\}^{6}$ complexes both have an experimentally and computationally determined $S=1\left(\mathrm{Fe}^{\mathrm{IV}}-\mathrm{NO}^{-}\right)$ground state ${ }^{52}$ however, optimization by B3LYP/def2-TZVP determined the $S=2$ state in $\mathrm{Cl}_{3} \mathrm{FeNO}$ to be the lowest in energy by $-20.3 \mathrm{kcal} / \mathrm{mol}$. CASSCF calculation on the $S=2$ spin state showed highly covalent bonding character between the $\mathrm{Fe}_{\mathrm{z} 2}$ and $\mathrm{NO} \mathrm{p}_{\mathrm{x}}$ orbitals with $1.35 \mathrm{e}^{-}$in
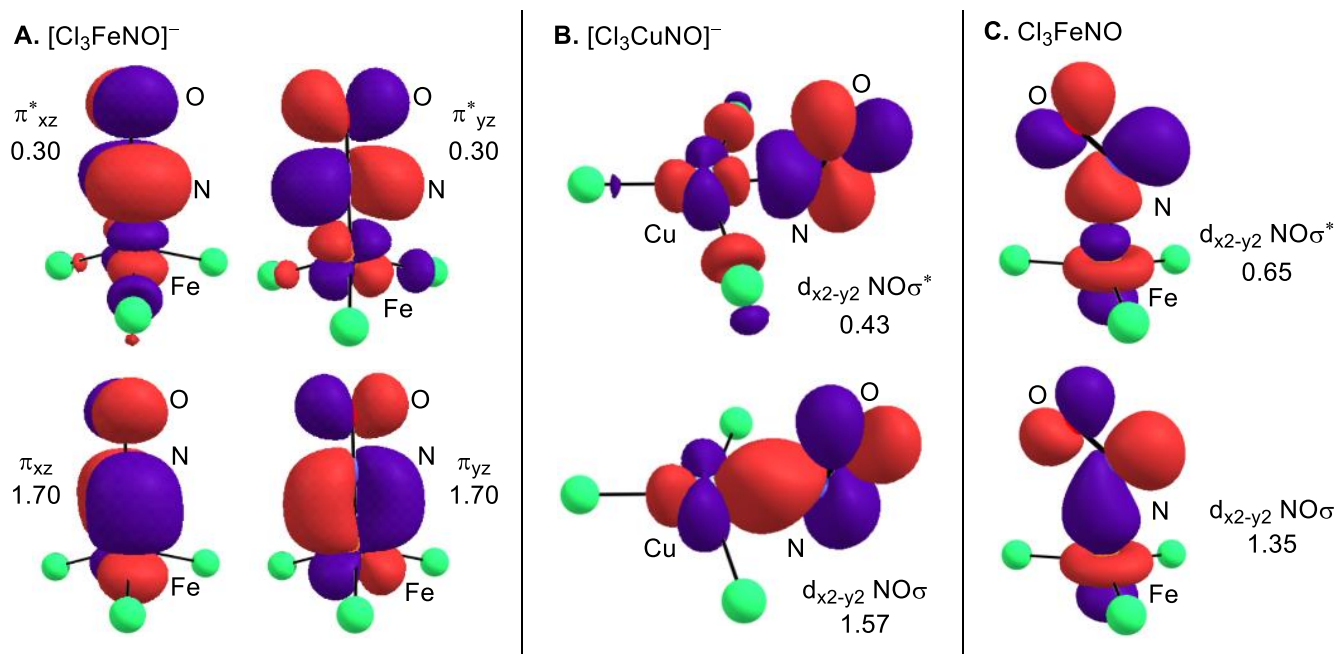

Figure 5. Partially occupied, covalent metal-NO frontier orbitals resulting from $\mathrm{CASSCF}$ calculations of the electronic ground states of $(\mathrm{A})\left[\mathrm{Cl}_{3} \mathrm{FeNO}^{-}\right.$ $[9 \mathrm{e}, 13 \mathrm{o}],(\mathrm{B})\left[\mathrm{Cl}_{3} \mathrm{CuNO}\right]^{-}[10 \mathrm{e}, 13 \mathrm{o}]$, and $(\mathrm{C}) \mathrm{Cl}_{3} \mathrm{FeNO}[6 \mathrm{e}, 13 \mathrm{o}]$. 
the bonding orbital and $0.65 \mathrm{e}^{-}$in the antibonding orbital (Figure $1 \mathrm{D})$, similar to $\left[\mathrm{Cl}_{3} \mathrm{CuNO}\right]^{-.46}$ Post-localization recalculation of the $\mathrm{CI}$ coefficients show $\mathrm{Cl}_{3} \mathrm{FeNO}$ exhibits about $93 \%$ $\mathrm{Fe}^{\mathrm{III}}-\mathrm{NO}^{\circ}$ character as the leading configuration, and $\mathrm{Fe}^{\mathrm{II}}-\mathrm{NO}^{+}$ contributes about $4.6 \%$ to the ground state as the second leading configuration. The increase in $\mathrm{NO}^{+}$character in the $\mathrm{Cl}_{3} \mathrm{FeNO}$ complex as compared to the $\left[\mathrm{Cl}_{3} \mathrm{FeNO}\right]^{-}$anion is consistent with our experimental observation that the $\mathrm{Fe}^{\mathrm{III}}$ complex, but not $\mathrm{Fe}^{\mathrm{II}}$, is able to mediate an oxidative coupling reaction to form $S$-nitrosothiols.

\section{SUMMARY AND CONCLUSIONS}

In contrast to the $\mathrm{RS}^{*}$ expulsion mechanism from the $\kappa^{1}-\mathrm{N}$ RSNO species invoked during NO` release from SNP, reaction of the high-spin $\left[\mathrm{Cl}_{3} \mathrm{Fe}^{\mathrm{II}}\right]^{-}$motif with $S$-nitrosothiol generates iron(III) thiolate and free NO*. Detailed in situ spectroscopic studies, including UV-vis, Mossbauer, and IR, suggest that coordination of the S-atom to the iron(II) center is necessary to promote $\mathrm{S}-\mathrm{N}$ bond cleavage. Importantly, iron(III) chloride complexes can also promote the formation of $S$-nitrosothiol when $\mathrm{NO}^{-}$is in excess. Our CASSCF results, when paired alongside our experimental studies, highlight the possibility of the use of computation to predict the $\mathrm{NO}^{-/{ }^{+}+}$reactivity of a series of metal nitrosyl complexes.

One central question that remains unanswered within the literature is how Fe centers promote the storage of $\mathrm{NO}^{\circ}$ as $S$-nitrosothiols, while also being efficient for the decomposition of RSNOs to $\mathrm{NO}^{\circ}$ and disulfide. We believe the answer to this question lies within the ability of $\mathrm{NO}^{*}$ to irreversibly bind to the $\mathrm{Fe}^{\mathrm{II}}$ center ligated by weak field ligands, ${ }^{34-37}$ shutting down coordination of $S$-nitrosothiol, which is a crucial step in its decomposition (Scheme 3 ). Since $\left[\mathrm{Cl}_{3} \mathrm{FeNO}\right]^{-}$can be easily converted to the DNIC $\left[\mathrm{Cl}_{2} \mathrm{Fe}(\mathrm{NO})_{2}\right]^{-}$in the presence of excess $\mathrm{NO}^{*},{ }^{39}$ our study also provides a potential explanation for the formation of DNIC and $S$-nitrosothiol frequently observed during cellular protein $S$-nitrosation, ${ }^{10,11}$ and demonstrate a strategy available to nature to reversibly modulate biological $\mathrm{NO}^{*}$ concentration with labile iron ions.

\section{ASSOCIATED CONTENT}

The Supporting information is available free of charge on the ACS Publications website at DOI:.

Experimental details, including characterization data, spectra, computational procedures and results.

Crystallographic data for

$\mathrm{TBA}_{3}\left[\mathrm{Cl}_{6} \mathrm{Fe}^{\mathrm{II}}{ }_{2}\right] \cdot\left[\mathrm{Cl}_{3} \mathrm{Fe}^{\mathrm{II}}\left(\mathrm{H}_{2} \mathrm{O}\right)\right](\mathrm{CSD}: 2057290)$

\section{AUTHOR INFORMATION}

\section{Corresponding Author}

*zhang.8941@osu.edu

\section{Notes}

The authors declare no competing financial interest.

\section{ACKNOWLEDGMENT}

We acknowledge the Ohio Supercomputer Center for high-performance computing resources, and Prof. Alexander Sokolov for help with CASSCF calculations. This publication is based on work funded by National Science Foundation under award no. CHE-1904560. The authors thank The Ohio State
University Department of Chemistry and Biochemistry for additional financial support.

\section{REFERENCES}

(1) Ignarro, L. J. Nitric Oxide: Biology and Pathobiology; Elsevier: Amsterdam, 2009.

(2) Rassaf, T.; Kleinbongard, P.; Preik, M.; Dejam, A.; Gharini, P.; Lauer, T.; Erckenbrecht, J.; Duschin, A.; Schulz, R.; Heusch, G.; Feelisch, M.; Kelm, M. Plasma Nitrosothiols Contribute to the Systemic Vasodilator Effects of Intravenously Applied NO: Experimental and Clinical Study on the Fate of NO in Human Blood. Circ. Res. 2002, 91, 470-477.

Broniowska, K. A.; Hogg, N. The Chemical Biology of SNitrosothiols. Antioxidants Redox Signal. 2012, 17, 969980 .

Hess, D. T.; Matsumoto, A.; Kim, S. O.; Marshall, H. E.; Stamler, J. S. Protein S-Nitrosylation: Purview and Parameters. Nat. Rev. Mol. Cell. Biol. Nature Publishing Group February 2005, pp 150-166.

Anand, P.; Stamler, J. S. Enzymatic Mechanisms Regulating Protein S-Nitrosylation: Implications in Health and Disease. J. Mol. Med. 2012, 90, 233-244.

Melzer, M. M.; Mossin, S.; Cardenas, A. J. P.; Williams, K. D.; Zhang, S.; Meyer, K.; Warren, T. H. A Copper(II) Thiolate from Reductive Cleavage of an S-Nitrosothiol. Inorg. Chem. 2012, 51, 8658-8660.

Zhang, S.; Çelebi-Ölçüm, N.; Melzer, M. M.; Houk, K. N.; Warren, T. H. Copper(I) Nitrosyls from Reaction of Copper(II) Thiolates with S-Nitrosothiols: Mechanism of NO Release from RSNOs at Cu. J. Am. Chem. Soc. 2013, 135, 16746-16749.

Zhang, S.; Melzer, M. M.; Sen, S. N.; Çelebi-Ölçüm, N.; Warren, T. H. A Motif for Reversible Nitric Oxide Interactions in Metalloenzymes. Nat. Chem. 2016, 8, 663669.

(9) Zhang, C.; Biggs, T. D.; Devarie-Baez, N. O.; Shuang, S.; Dong, C.; Xian, M. S-Nitrosothiols: Chemistry and Reactions. Chem. Commun. 2017, 53, 11266-11277.

Li, Q.; Li, C.; Mahtani, H. K.; Du, J.; Patel, A. R.; Lancaster, J. R. Nitrosothiol Formation and Protection against Fenton Chemistry by Nitric Oxide-Induced Dinitrosyliron Complex Formation from Anoxia-Initiated Cellular Chelatable Iron Increase. J. Biol. Chem. 2014, 289, 19917-19927.

Bosworth, C. A.; Toledo, J. C.; Zmijewski, J. W.; Li, Q.; Lancaster, J. R. Dinitrosyliron Complexes and the Mechanism(s) of Cellular Protein Nitrosothiol Formation from Nitric Oxide. Proc. Natl. Acad. Sci. U. S. A. 2009, 106, 4671-4676.

(12) Hottinger, D. G.; Beebe, D. S.; Kozhimannil, T.; Prielipp, R. C.; Belani, K. G. Sodium Nitroprusside in 2014: A Clinical Concepts Review. J. Anaesthesiol. Clin. Pharmacol. 2014, 30, 462-471. 
Rhine, M. A.; Sanders, B. C.; Patra, A. K.; Harrop, T. C. Overview and New Insights into the Thiol Reactivity of Coordinated NO in $\{\mathrm{MNO}\}^{6 / 7 / 8}(\mathrm{M}=\mathrm{Fe}, \mathrm{Co})$ Complexes. Inorg. Chem. 2015, 54, 9351-9366.

(14) Hunt, A. P.; Lehnert, N. The Thiolate Trans Effect in Heme $\{\mathrm{FeNO}\}^{6}$ Complexes and Beyond: Insight into the Nature of the Push Effect. Inorg. Chem. 2019, 58, $11317-$ 11332 .

(15) Goodrich, Lauren, E. Model Complexes of Cytochrome P450 NOR, 2012.

(16) Weichsel, A.; Maes, E. M.; Andersen, J. F.; Valenzuela, J. G.; Shokhireva, T. K.; Walker, F. A.; Montfort, W. R. Heme-Assisted S-Nitrosation of a Proximal Thiolate in a Nitric Oxide Transport Protein. Proc. Natl. Acad. Sci. U. S. A. 2005, 102, 594-599.

(17) Basu, S.; Keszler, A.; Azarova, N. A.; Nwanze, N.; Perlegas, A.; Shiva, S.; Broniowska, K. A.; Hogg, N.; Kim-Shapiro, D. B. A Novel Role for Cytochrome c: Efficient Catalysis of S-Nitrosothiol Formation. Free Radic. Biol. Med. 2010, 48, 255-263.

(18) Franke, A.; Stochel, G.; Suzuki, N.; Higuchi, T.; Okuzono, K.; Van Eldik, R. Mechanistic Studies on the Binding of Nitric Oxide to a Synthetic Heme-Thiolate Complex Relevant to Cytochrome P450. J. Am. Chem. Soc. 2005, 127, 5360-5375.

(19) Gao, Y.; Mossing, B.; Wu, G. Direct NMR Detection of the Unstable "Red Product" from the Reaction between Nitroprusside and 2-Mercaptosuccinic Acid. Dalt. Trans. 2015, 44, 20338-20343.

(20) Schwane, J. D.; Ashby, M. T. FTIR Investigation of the Intermediates Formed in the Reaction of Nitroprusside and Thiolates. J. Am. Chem. Soc. 2002, 124, 6822-6823.

(21) Perissinotti, L. L.; Estrin, D. A.; Leitus, G.; Doctorovich, F. A Surprisingly Stable S-Nitrosothiol Complex. J. Am. Chem. Soc. 2006, 128, 2512-2513.

(22) Hosseininasab, V.; McQuilken, A. C.; Bakhoda, A. (Gus); Bertke, J. A.; Timerghazin, Q. K.; Warren, T. H. Lewis Acid Coordination Redirects S-Nitrosothiol Signaling Output. Angew. Chemie 2020, 132, 10946-10950.

(23) Timerghazin, Q. K.; Peslherbe, G. H.; English, A. M. Resonance Description of S-Nitrosothiols: Insights into Reactivity. Org. Lett. 2007, 9, 3049-3052.

(24) Hendinejad, N.; Timerghazin, Q. K. Biological Control of: S -Nitrosothiol Reactivity: Potential Role of SigmaHole Interactions. Phys. Chem. Chem. Phys. 2020, 22, 6595-6605.

(25) Roncaroli, F.; Van Eldik, R.; Olabe, J. A. Release of NO from Reduced Nitroprusside Ion. Iron-Dinitrosyl Formation and NO-Disproportionation Reactions. Inorg. Chem. 2005, 44, 2781-2790.

(26) Petrat, F.; de Groot, H.; Sustmann, R.; Rauen, U. The Chelatable Iron Pool in Living Cells: A Methodically Defined Quantity. Biol. Chem. 2002, 383, 489-502.
Lok, H. C.; Sahni, S.; Jansson, P. J.; Kovacevic, Z.; Hawkins, C. L.; Richardson, D. R. A Nitric Oxide Storage and Transport System That Protects Activated Macrophages from Endogenous Nitric Oxide Cytotoxicity. J. Biol. Chem. 2016, 291, 27042-27061.

(28) Damasceno, F. C.; Condeles, A. L.; Lopes, A. K. B.; Facci, R. R.; Linares, E.; Truzzi, D. R.; Augusto, O.; Toledo, J. C. The Labile Iron Pool Attenuates Peroxynitrite-Dependent Damage and Can No Longer Be Considered Solely a pro-Oxidative Cellular Iron Source. J. Biol. Chem. 2018, 293, 8530-8542.

Kruszewski, M. Labile Iron Pool: The Main Determinant of Cellular Response to Oxidative Stress. Mutat. Res. Fundam. Mol. Mech. Mutagen. 2003, 531, 81-92.

(30) Fitzpatrick, J.; Kim, E. Synthetic Modeling Chemistry of Iron-Sulfur Clusters in Nitric Oxide Signaling. Acc. Chem. Res. 2015, 48, 2453-2461.

(31) Tran, C. T.; Kim, E. Acid-Dependent Degradation of a [2Fe-2S] Cluster by Nitric Oxide. Inorg. Chem. 2012, 51, 10086-10088.

Crack, J. C.; Smith, L. J.; Stapleton, M. R.; Peck, J.; Watmough, N. J.; Buttner, M. J.; Buxton, R. S.; Green, J.; Oganesyan, V. S.; Thomson, A. J.; Le Brun, N. E. Mechanistic Insight into the Nitrosylation of the [4Fe-4S] Cluster of WhiB-like Proteins. J. Am. Chem. Soc. 2011, 133, 1112-1121.

(33) Harrop, T. C.; Tonzetich, Z. J.; Reisner, E.; Lippard, S. J. Reactions of Synthetic [2Fe-2S] and [4Fe-4S] Clusters with Nitric Oxide and Nitrosothiols. J. Am. Chem. Soc. 2008, 130, 15602-15610.

(34) McQuilken, A. C.; Matsumura, H.; Dürr, M.; Confer, A. M.; Sheckelton, J. P.; Siegler, M. A.; McQueen, T. M.; Ivanović-Burmazović, I.; Moënne-Loccoz, P.; Goldberg, D. P. Photoinitiated Reactivity of a Thiolate-Ligated, Spin-Crossover Nonheme $\{\mathrm{FeNO}\}^{7}$ Complex with Dioxygen. J. Am. Chem. Soc. 2016, 138, 3107-3117.

Ting-Wah Chu, C.; Yip-Kwai Lo, F.; Dahl, L. F. Synthesis and Stereochemical Analysis of the $\left[\mathrm{Fe}_{4}(\mathrm{NO})_{4}\left(\mu_{3}-\mathrm{S}\right)_{4}\right] \mathrm{n}$ Series $(\mathrm{n}=0,-1)$ Which Possesses a Cubanelike $\mathrm{Fe}_{4} \mathrm{~S}_{4}$ Core: Direct Evidence for the Antibonding Tetrametal Character of the Un. J. Am. Chem. Soc. 1982, 104, 3409-3422.

(36) Harrop, T. C.; Song, D.; Lippard, S. J. Interaction of Nitric Oxide with Tetrathiolato Iron(II) Complexes: Relevance to the Reaction Pathways of Iron Nitrosyls in Sulfur-Rich Biological Coordination Environments. J. Am. Chem. Soc. 2006, 128, 3528-3529.

(37) Conradie, J.; Quarless, D. A.; Hsu, H. F.; Harrop, T. C.; Lippard, S. J.; Koch, S. A.; Ghosh, A. Electronic Structure and FeNO Conformation of Nonheme Iron-Thiolate-NO Complexes: An Experimental and DFT Study. J. Am. Chem. Soc. 2007, 129, 10446-10456.

Sun, J. S.; Zhao, H.; Ouyang, X.; Clérac, R.; Smith, J. A.; Clemente-Juan, J. M.; Gómez-Garcia, C.; Coronado, E.; Dunbar, K. R. Structures, Magnetic Properties, and 
Reactivity Studies of Salts Containing the Dinuclear Anion $\left[\mathrm{M}_{2} \mathrm{Cl}_{6}\right]^{2-}(\mathrm{M}=\mathrm{Mn}, \mathrm{Fe}, \mathrm{Co})$. Inorg. Chem. 1999, $38,5841-5855$.

(39) In-Iam, A.; Wolf, M.; Wilfer, C.; Schaniel, D.; Woike, T.; Klüfers, P. \{FeNO $\}^{7}$-Type Halogenido Nitrosyl Ferrates: Syntheses, Bonding, and Photoinduced Linkage Isomerism. Chem. Eur. J. 2019, 25, 1304-1325.

(40) Kohlschütter, V.; Sazanoff, P. Zur Kenntnis Der Metallnitrosoverbindungen. Berichte der Dtsch. Chem. Gesellschaft 1911, 44, 1423-1432.

(41) Begel, S.; Puchta, R.; Sutter, J.; Heinemann, F. W.; Dahlenburg, L.; Eldik, R. Van. Studies on the Reaction of Iron(II) with NO in a Noncoordinating Ionic Liquid. Inorg. Chem. 2015, 54, 6763-6775.

(42) Steimann, M.; Nagel, U.; Grenz, R.; Beck, W. Die Struktur von Trichloronitrosylferrat, $\left[\mathrm{Fe}(\mathrm{NO}) \mathrm{Cl}_{3}\right]^{-}$. J. Organomet. Chem. 1983, 247, 171-174.

(43) Ivanova, L. V.; Cibich, D.; Deye, G.; Talipov, M. R.; Timerghazin, Q. K. Modeling of S-Nitrosothiol-Thiol Reactions of Biological Significance: HNO Production by S-Thiolation Requires a Proton Shuttle and Stabilization of Polar Intermediates. ChemBioChem 2017, 18, 726738 .

(44) Khomyakov, D. G.; Timerghazin, Q. K. Toward Reliable Modeling of S-Nitrosothiol Chemistry: Structure and Properties of Methyl Thionitrite $\left(\mathrm{CH}_{3} \mathrm{SNO}\right)$, an SNitrosocysteine Model. J. Chem. Phys. 2017, 147, 44305.

(45) Melzer, M. M.; Jarchow-Choy, S.; Kogut, E.; Warren, T. $\mathrm{H}$. Reductive Cleavage of O-, S-, and N-Organonitroso Compounds by Nickel(I) $\beta$-Diketiminates. Inorg. Chem. 2008, 47, 10187-10189.

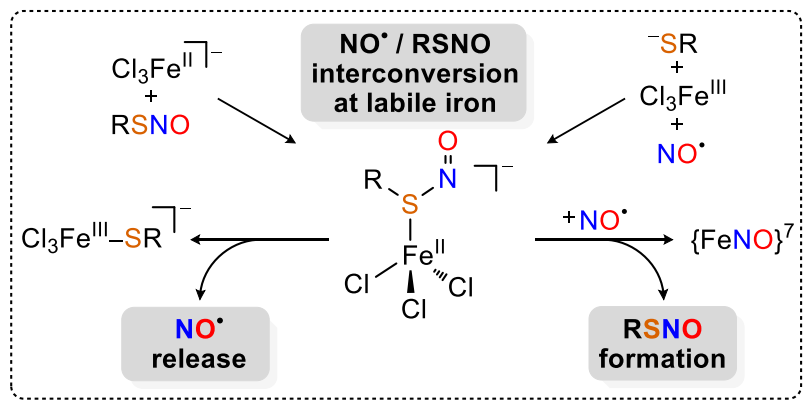

Synopsis: Simple $\mathrm{Fe}^{\mathrm{II}} / \mathrm{Fe}^{\mathrm{III}}$ chloride salt can mediate the reversible interconversion of $\mathrm{NO}^{*}$ and $S$-nitrosothiols via $\mathrm{Fe}-\mathrm{S}$ interaction. This new mechanism is different from the one previously proposed for $\mathrm{NO}^{*}$ release from the "red product" $\kappa^{1}$ $\mathrm{N}$ bound $S$-nitrosothiol $\mathrm{Fe}^{\mathrm{II}}$ complex, $\left[(\mathrm{CN})_{5} \mathrm{Fe}\left(\kappa^{1}-\mathrm{N}-\right.\right.$ RSNO) $]^{3-}$
(46) Bower, J. K.; Sokolov, A. Y.; Zhang, S. Four-Coordinate Copper Halonitrosyl $\{\mathrm{CuNO}\}^{10}$ Complexes. Angew. Chem. Int. Ed. 2019, 58, 10225-10229.

Wright, A. M.; Wu, G.; Hayton, T. W. Structural Characterization of a Copper Nitrosyl Complex with a $\{\mathrm{CuNO}\}^{10}$ Configuration. J. Am. Chem. Soc. 2010, 132, 14336-14337.

(48) Tomson, N. C.; Crimmin, M. R.; Petrenko, T.; Rosebrugh, L. E.; Sproules, S.; Christopher Boyd, W.; Bergman, R. G.; Debeer, S.; Dean Toste, F.; Wieghardt, K. A Step beyond the Feltham-Enemark Notation: Spectroscopic and Correlated $\mathrm{Ab}$ Initio Computational Support for an Antiferromagnetically Coupled M(II)-(NO)- Description of Tp*M(NO) (M = Co, Ni). J. Am. Chem. Soc. 2011, 133, $18785-18801$

(49) Monsch, G.; Klüfers, P. $\left[\mathrm{Fe}\left(\mathrm{H}_{2} \mathrm{O}\right)_{5}(\mathrm{NO})\right]^{2+}$, the "BrownRing" Chromophore. Angew. Chem. Int. Ed. 2019, 58, 8566-8571.

(50) Griffith, W. P.; Lewis, J.; Wilkinson, G. Some Nitric Oxide Complexes of Iron and Copper. J. Chem. Soc. 1958, 3993-3998.

(51) Radón, M.; Broclawik, E.; Pierloot, K. Electronic Structure of Selected $\{\mathrm{FeNO}\}^{7}$ Complexes in Heme and Non-Heme Architectures: A Density Functional and Multireference Ab Initio Study. J. Phys. Chem. B 2010, $114,1518-1528$.

(52) Lehnert, N.; Fujisawa, K.; Camarena, S.; Dong, H. T.; White, C. J. Activation of Non-Heme Iron-Nitrosyl Complexes: Turning up the Heat. ACS Catal. American Chemical Society November 1, 2019, pp 10499-10518. 
Electronic Supporting Information for:

Iron (II/III) Halide Complexes Promote the Interconversion of Nitric Oxide and $S$ nitrosothiols through Reversible Fe-S Interaction

Anna L. Poptic, ${ }^{a}$ and Shiyu Zhang ${ }^{\mathrm{a}}$

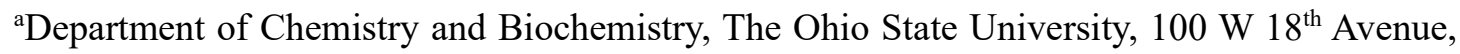
Columbus, Ohio 43210, USA

\section{Contents:}

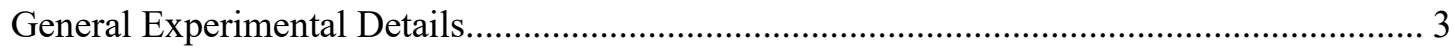

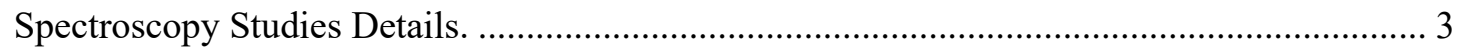

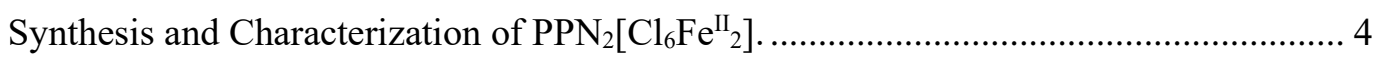

Synthesis and Characterization of $\mathrm{PPN}\left[\mathrm{Cl}_{3} \mathrm{FeNO}\right]\left(\{\mathrm{FeNO}\}^{7}\right)$.................................... 4

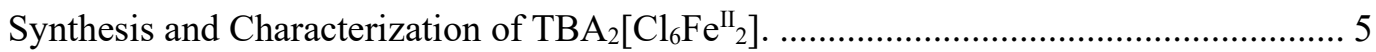

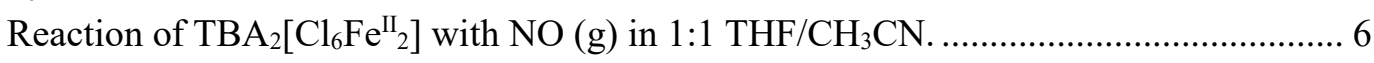

Solution magnetic susceptibility measurement for $\mathrm{PPN}\left[\mathrm{Cl}_{3} \mathrm{FeNO}\right]$ with Evans method .. 6

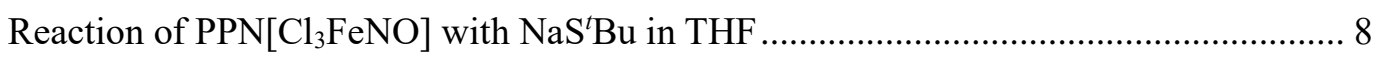

Reaction of $\mathrm{TBA}_{2}\left[\mathrm{Cl}_{6} \mathrm{Fe}_{2}{ }_{2}\right]$ with $\mathrm{Ph}_{3} \mathrm{CSNO}$ in $1: 1 \mathrm{CH}_{3} \mathrm{CN} / \mathrm{THF}$.................................. 8

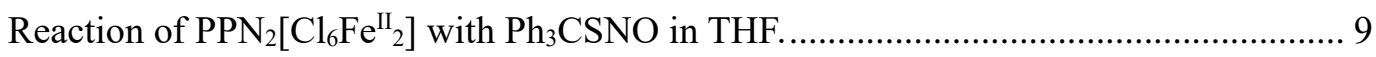

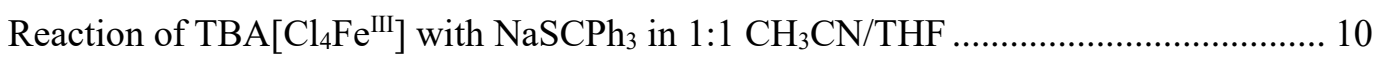

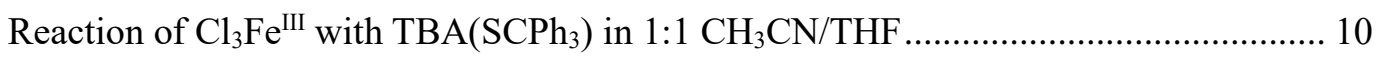

Determining the stoichiometry of $\mathrm{NaSCPh}_{3}$ to $\mathrm{TBA}\left[\mathrm{Cl}_{4} \mathrm{Fe}^{\mathrm{III}}\right]$ with $\mathrm{UV}$-vis titration. ......11

Determining the stoichiometry of $\mathrm{TBA}\left(\mathrm{SCPh}_{3}\right)$ to $\mathrm{Cl}_{3} \mathrm{Fe}^{\mathrm{III}}$ with $\mathrm{UV}$-vis titration........... 12

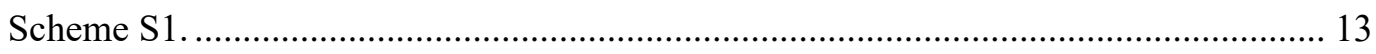

Quantification of $\mathrm{Ph}_{3} \mathrm{CS}-\mathrm{SCPh}_{3}$ and $\left[\mathrm{Cl}_{6} \mathrm{Fe}^{\mathrm{II}}{ }_{2}\right]^{2-}$ from $\mathrm{Fe}^{\mathrm{III}} \mathrm{Cl}_{3}+1$ eq. $\mathrm{TBA}\left(\mathrm{SCPh}_{3}\right) \ldots . . .13$

Synthesis and characterization of $\mathrm{TBA}_{2}\left[\mathrm{Cl}_{6}{ }^{57} \mathrm{Fe}^{\mathrm{II}}{ }_{2}\right]$ for Mössbauer spectroscopy ........... 14

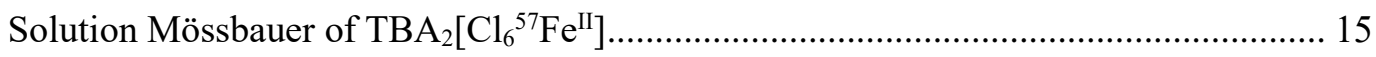

Synthesis and characterization of $\mathrm{TBA}\left[\mathrm{Cl}_{4}{ }^{57} \mathrm{Fe}^{\mathrm{III}}\right]$ for Mössbauer spectroscopy............. 15

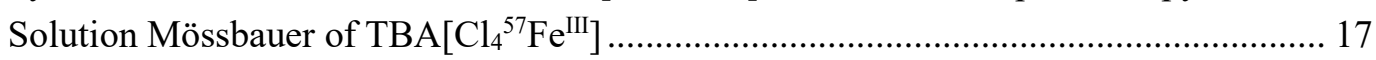

Solution Mössbauer of the reaction of $\mathrm{TBA}_{2}\left[\mathrm{Cl}_{6}{ }^{57} \mathrm{Fe}^{\mathrm{II}_{2}}\right]+2 \mathrm{Ph}_{3} \mathrm{CSNO} \ldots \ldots \ldots \ldots \ldots \ldots \ldots \ldots \ldots . . . . . . . . . . .17$

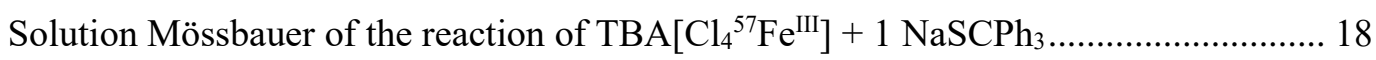

In situ solution IR monitoring of $\mathrm{TBA}_{2}\left[\mathrm{Cl}_{6} \mathrm{Fe}_{2}{ }_{2}\right]+2$ eq. $\mathrm{Ph}_{3} \mathrm{CSNO}$ in THF- $d_{8} \ldots \ldots \ldots \ldots . . . .19$

In situ solution IR monitoring of $\mathrm{TBA}_{2}\left[\mathrm{Cl}_{6} \mathrm{Fe}^{\mathrm{II}}{ }_{2}\right]+2 \mathrm{Ph}_{3} \mathrm{CS}^{15} \mathrm{NO}$ in THF- $d_{8} \ldots \ldots \ldots \ldots \ldots . . . . .20$

In situ solution IR of $\mathrm{Cl}_{3} \mathrm{Fe}^{\mathrm{III}}+\mathrm{TBA}\left(\mathrm{SCPh}_{3}\right)$ and $\mathrm{NO}(\mathrm{g})$ in 9:1 THF- $d_{8} / \mathrm{CD}_{3} \mathrm{CN}$.......... 21

In situ solution IR calibration curve for TBA[Cl $\left.\mathrm{Cl}_{3} \mathrm{FeNO}\right]$ in 9:1 THF- $d_{8} / \mathrm{CD}_{3} \mathrm{CN}$............ 22

In situ solution IR calibration curve for $\mathrm{Ph}_{3} \mathrm{CSNO}$ in 9:1 THF- $d_{8} / \mathrm{CD}_{3} \mathrm{CN}$................... 23

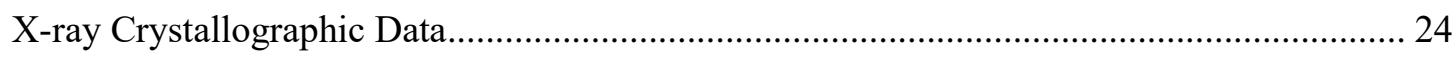

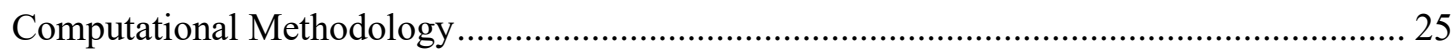

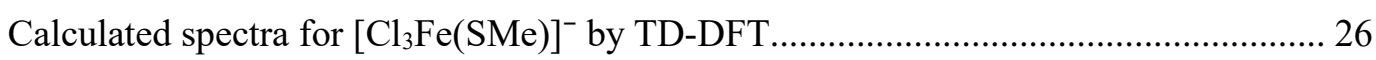

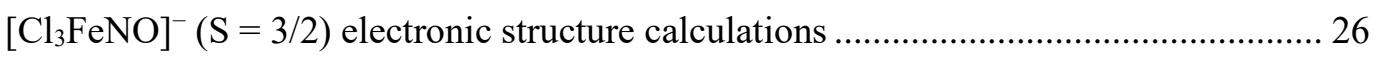

$\left[\mathrm{Cl}_{3} \mathrm{CuNO}^{-}(\mathrm{S}=1 / 2)\right.$ electronic structure calculations................................................ 29 
$\mathrm{Cl}_{3} \mathrm{Fe}^{\mathrm{III}} \mathrm{NO}(\mathrm{S}=2)$ electronic structure calculations ..

30

References.

33 


\section{General Experimental Details}

All syntheses and experiments were performed under a nitrogen atmosphere in an MBraun glovebox or using standard Schlenk techniques unless otherwise noted. Acetonitrile, tetrahydrofuran and diethyl ether were dried and degassed under nitrogen using a Pure Process Technologies (PPT, Nashua, NH) solvent purification system, and stored over $4 \AA$ molecular sieves. Extra dry methanol and acetone were purchased from Fischer Scientific or Sigma Aldrich and used as received. All glassware was dried at $120^{\circ} \mathrm{C}$ prior to use. Elemental analysis was performed by Midwest Micro Lab (Indianapolis, IN, http://midwestlab.com/). Tetrabutylammonium chloride salt ( $\mathrm{TBACl}$,), bis(triphenylphosphorylene)iminium chloride (PPNCl), anhydrous iron(II) chloride, iron(III) chloride, trimethylsilyl triflate (TMSOTf), tertbutyl mercaptan, and triphenylmethyl mercaptan were obtained from Fischer, Alfa Aesar, or Sigma-Aldrich, and used without further purification. ${ }^{57} \mathrm{Fe}(0)(95 \%+)$ and $\mathrm{Na}^{15} \mathrm{NO}_{2}\left({ }^{15} \mathrm{~N} 98 \%+\right)$ were obtained from Cambridge Isotope Laboratories and used without further purification. Nitric oxide gas was purchased from Praxair and purified with Ascarite (8-20 mesh, SigmaAldrich) before use. $\mathrm{NaS}^{\mathrm{t}} \mathrm{Bu}$ and $\mathrm{NaSCPh}_{3}$ were obtained from the corresponding thiol and $\mathrm{NaO}^{t} \mathrm{Bu}$ in THF. ${ }^{1} \mathrm{TBA}\left(\mathrm{SCPh}_{3}\right)$ was synthesized via cation exchange with the corresponding sodium thiolate and TBACl in THF. $\left.\mathrm{Ph}_{3} \mathrm{CSNO}^{2}, \mathrm{Ph}_{3} \mathrm{CS}^{15} \mathrm{NO}^{3}, \mathrm{TBA}\left[\mathrm{Cl}_{4} \mathrm{Fe}^{\mathrm{III}}\right]\right]^{4},{ }^{57} \mathrm{Fe}^{\mathrm{II}} \mathrm{Cl}_{2}{ }^{5}$, and ${ }^{57} \mathrm{Fe}^{\mathrm{III}} \mathrm{Cl}_{3}{ }^{6}$ were prepared based on literature procedures. Labeled ${ }^{15} \mathrm{NO}$ was generated from ferrocene, $\mathrm{Na}^{15} \mathrm{NO}_{2}$ and trimethylsilyl trifluoromethanesulfonate (TMSOTf) based on a previously reported literature procedure. ${ }^{7}$

\section{General Spectroscopic Details}

${ }^{1} \mathrm{H}$ NMR spectra were recorded on a Bruker Avance NEO $400 \mathrm{MHz}$ instrument or Bruker Avance III HD $600 \mathrm{MHz}$ instrument and referenced to the NMR residual solvent peaks. NMR yields were calculated using trimethoxybenzene as the internal standard. UV-vis spectra were collected on an Agilent Cary 60 spectrophotometer outfitted with a Unisoku Unispeks cryostat $\left(-100{ }^{\circ} \mathrm{C}\right.$ to $\left.+100{ }^{\circ} \mathrm{C}\right)$. In-situ solution-phase infrared spectroscopy studies were conducted with a Mettler Toledo RiRI15 spectrometer. ${ }^{57} \mathrm{Fe}$ Mössbauer spectra were measured on a constant acceleration spectrometer (SEE Co. Minneapolis, MN) with a Janis SHI-4 cryostat. Isomer shifts are quoted relative to $\alpha$-Fe foil $(<25 \mu \mathrm{m}$ thick $)$ at room temperature. Data were analyzed using the WMOSS version F software package. ${ }^{8}$ 


\section{Synthesis and Characterization of $\mathrm{PPN}_{2}\left[\mathrm{Cl}_{6} \mathrm{Fe}^{\mathrm{II}}{ }_{2}\right]$}

$\mathrm{PPN}_{2}\left[\mathrm{Cl}_{6} \mathrm{Fe}_{2}\right]$ was prepared according to a modified literature procedure. ${ }^{9} \mathrm{PPNCl}(0.9212 \mathrm{~g}$, $1.605 \mathrm{mmol}$ ) was dissolved in methanol (ca. $2 \mathrm{~mL}$ ) and added to a stirring suspension of $\mathrm{Fe}^{\mathrm{II}} \mathrm{Cl}_{2}$ (0.2034 g, $1.605 \mathrm{mmol}, 1$ equiv.) in acetone (ca. $10 \mathrm{~mL}$ ). Upon addition of $\mathrm{PPNCl}$, the mixture became a yellow homogenous solution, then a yellow suspension after stirring for 1 hour. The solution was filtered through a plug of Celite, and the Celite pad was washed with additional acetone $(3 \times 2 \mathrm{~mL})$ to ensure complete transfer. After concentration of the filtrate under vacuum, diethyl ether (ca. $3 \mathrm{~mL}$ ) was layered on top and the vial was placed in a $-35{ }^{\circ} \mathrm{C}$ freezer. The colorless crystals that formed overnight were collected by filtration and dried under vacuum to yield $\mathrm{PPN}_{2}\left[\mathrm{Cl}_{6} \mathrm{Fe}_{2}\right]$ (1.0232 g, 91.0\%). The identity of the compound was confirmed by unit cell analysis of the single crystals by X-ray diffractometry. ${ }^{9}$

\section{Synthesis and Characterization of $\mathrm{PPN}_{[\mathrm{Cl}} \mathrm{FeNO}_{3}\left(\{\mathrm{FeNO}\}^{7}\right)$}

PPN $\left[\mathrm{Cl}_{3} \mathrm{FeNO}\right]$ was prepared according to a modified literature procedure. ${ }^{10}$ Solid $\mathrm{PPN}_{2}\left[\mathrm{Cl}_{6} \mathrm{Fe}_{2}{ }_{2}\right]$ (31.0 mg, $\left.28.4 \mu \mathrm{mol}\right)$ was dissolved in a minimum amount of methanol (ca. 1.5 $\mathrm{mL})$. The solution was chilled in a $-35^{\circ} \mathrm{C}$ freezer. Gaseous $\mathrm{NO}^{*}(20.0 \mathrm{~mL})$ was bubbled through the solution until no further color change from clear to green could be observed. Diethyl ether (ca. $1.5 \mathrm{~mL}$ ) was layered on top of this solution with a syringe. The solution was stored at $-35{ }^{\circ} \mathrm{C}$ overnight to obtain dark green needle-shaped crystals (14.5 mg, 44\%.). The identity of the product was confirmed via unit cell analysis of the crystals by X-ray diffractometry. ${ }^{10}$ The PPN $\left[\mathrm{Cl}_{3} \mathrm{Fe}^{15} \mathrm{NO}\right]$ was prepared analogously with $\mathrm{PPN}_{2}\left[\mathrm{Cl}_{6} \mathrm{Fe}^{\mathrm{II}}{ }_{2}\right]$ and ${ }^{15} \mathrm{NO}$. The UV-vis sample was prepared via $\mathrm{NO}$ injection to an $\mathrm{CH}_{3} \mathrm{CN}$ solution of $\mathrm{PPN}\left[\mathrm{Cl}_{3} \mathrm{FeNO}\right](2.5 \mathrm{mM}, 3 \mathrm{~mL}, 7.5$ $\mu$ mol) (Figure S1). Solution IR samples were prepared by redissolving $\mathrm{PPN}\left[\mathrm{Cl}_{3} \mathrm{FeNO}\right]$ or $\mathrm{PPN}\left[\mathrm{Cl}_{3} \mathrm{Fe}^{15} \mathrm{NO}\right]$ in DCM $(20 \mathrm{mM}, 1 \mathrm{~mL}, 20 \mu \mathrm{mol})$ under ambient air (Figure S2). The Mössbauer sample was prepared using approximately $30 \mathrm{mg}$ of sample suspended in paratone$\mathrm{N}$ oil and loaded under liquid $\mathrm{N}_{2}$ to avoid air and moisture (Figure S3). Mössbauer data were collected at $4 \mathrm{~K}$ in the absence of an applied magnetic field. 


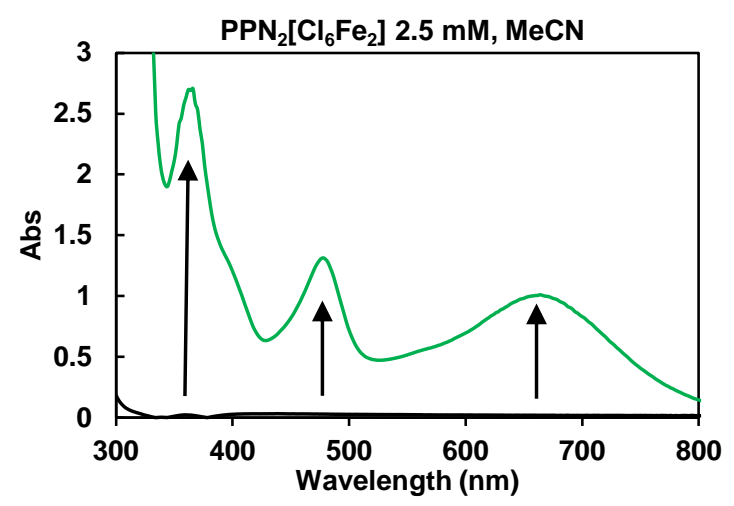

Figure S1. Reaction of $\mathrm{PPN}_{2}\left[\mathrm{Cl}_{6} \mathrm{Fe}^{\mathrm{II}}{ }_{2}\right]$ with 1 eq. $\mathrm{NO}(\mathrm{g})$ to produce $\mathrm{PPN}\left[\mathrm{Cl}_{3} \mathrm{FeNO}\right]$ (365 $\mathrm{nm}\left(\varepsilon=1080 \mathrm{M}^{-1} \mathrm{~cm}^{-1}\right), 480 \mathrm{~nm}\left(\varepsilon=500 \mathrm{M}^{-1} \mathrm{~cm}^{-1}\right), 660 \mathrm{~nm}\left(\varepsilon=400 \mathrm{M}^{-1} \mathrm{~cm}^{-1}\right)$.

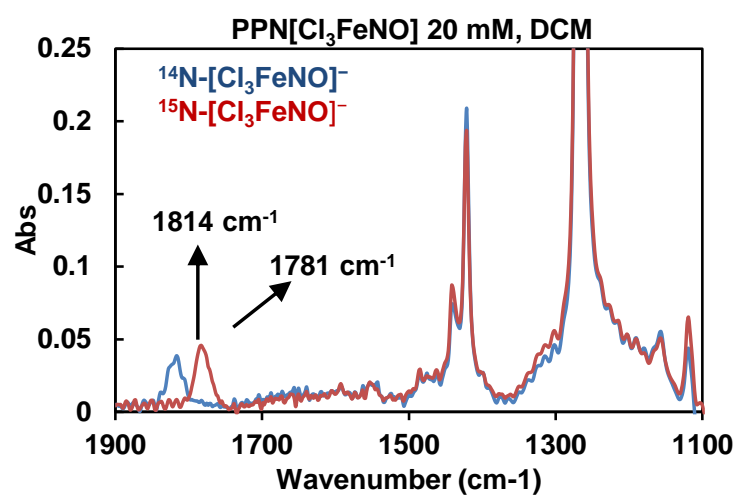

Figure S2. Solution IR spectrum of ${ }^{14} \mathrm{~N}$ and ${ }^{15} \mathrm{~N}-\mathrm{PPN}\left[\mathrm{Cl}_{3} \mathrm{FeNO}\right]$.

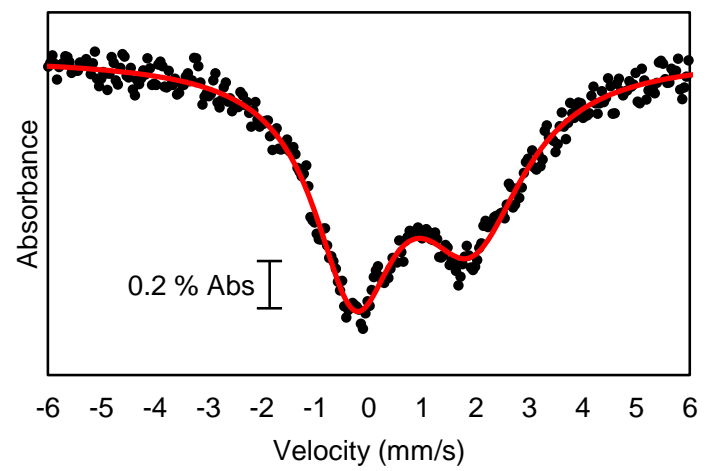

Figure S3. ${ }^{57} \mathrm{Fe}$ Mössbauer spectrum (natural abundance) of PPN $\left[\mathrm{Cl}_{3} \mathrm{FeNO}\right](4 \mathrm{~K}, 0 \mathrm{~T})$. Experimenal data (black dots), best fit (red line) $\left(\chi^{2}=0.521\right) . \delta=0.58 \mathrm{~mm} \mathrm{~s}-1,\left|\Delta \mathrm{E}_{\mathrm{Q}}\right|=$ $1.53 \mathrm{~mm} \mathrm{~s}^{-1}, \Gamma_{\mathrm{L}}=1.30, \Gamma_{\mathrm{R}}=1.70$.

\section{Synthesis and Characterization of $\mathrm{TBA}_{2}\left[\mathrm{Cl}_{6} \mathrm{Fe}^{\mathrm{II}}{ }_{2}\right]$}

$\mathrm{TBA}_{2}\left[\mathrm{Cl}_{6} \mathrm{Fe}_{2}{ }_{2}\right]$ was prepared in a similar manner to $\mathrm{PPN}_{2}\left[\mathrm{Cl}_{6} \mathrm{Fe}_{2}{ }_{2}\right]$. Under ambient air, an acetone solution of TBACl $(0.5473 \mathrm{~g}, 1.969 \mathrm{mmol})$ was added to a stirred $10 \mathrm{~mL}$ suspension of an acetone solution of $\mathrm{Fe}^{\mathrm{II}} \mathrm{Cl}_{2}(0.2496 \mathrm{~g}, 1.969 \mathrm{mmol})$. Upon addition of $\mathrm{TBACl}$, the mixture 
became homogenous and golden yellow. The solution was stirred overnight to give a pale yellow precipitate and a yellow solution. The solution was filtered through Celite and the precipitate was washed with acetone $(3 \times 2 \mathrm{~mL})$. After concentration of the filtrate under vacuum, diethyl ether (ca. $3 \mathrm{~mL}$ ) was added and the vial placed in a $-35{ }^{\circ} \mathrm{C}$ freezer. The colorless crystals that formed overnight were collected by filtration and dried under vacuum to yield $\mathrm{TBA}_{2}\left[\mathrm{Cl}_{6} \mathrm{Fe}_{2}{ }_{2}\right](0.4201 \mathrm{~g}, 53.0 \%$, based on $\mathrm{Fe})$. The identity of the compound was determined by single-crystal x-ray diffraction. Elemental analysis, Calcd for $\mathrm{C}_{32} \mathrm{H}_{72} \mathrm{Cl}_{6} \mathrm{Fe}_{2} \mathrm{~N}_{2} \mathrm{C}$, 47.49; H, 8.97; N, 3.46. Found C, 46.84; H, 8.56; N, 3.51.

\section{Reaction of $\mathrm{TBA}_{2}\left[\mathrm{Cl}_{6} \mathrm{Fe}^{\mathrm{II}}{ }_{2}\right]$ with $\mathrm{NO}(\mathrm{g})$ in $1: 1 \mathrm{THF} / \mathrm{CH}_{3} \mathrm{CN}$.}

A solution of $\mathrm{TBA}_{2}\left[\mathrm{Cl}_{6} \mathrm{Fe}^{\mathrm{II}} 2\right]\left(3.0 \mathrm{~mL}, 0.25 \mathrm{mM}, 0.75 \mu \mathrm{mol}, 1: 1 \mathrm{CH}_{3} \mathrm{CN} / \mathrm{THF}\right)$ was placed in a quartz cuvette with a Schlenk attachment under a nitrogen atmosphere. NO* $(0.1 \mathrm{~mL}, 4.1 \mu \mathrm{mol}$, 5.5 equiv.) was then added to the cuvette at room temperature under a positive flow of nitrogen to generate $\mathrm{TBA}\left[\mathrm{Cl}_{3} \mathrm{FeNO}\right]$, as identified by $\mathrm{UV}$-vis features at $365 \mathrm{~nm}, 480 \mathrm{~nm}, 655 \mathrm{~nm}$. The molar absorbtivity values of these features are similar to those corresponding to $\mathrm{PPN}\left[\mathrm{Cl}_{3} \mathrm{FeNO}\right]$ (Figure S4).

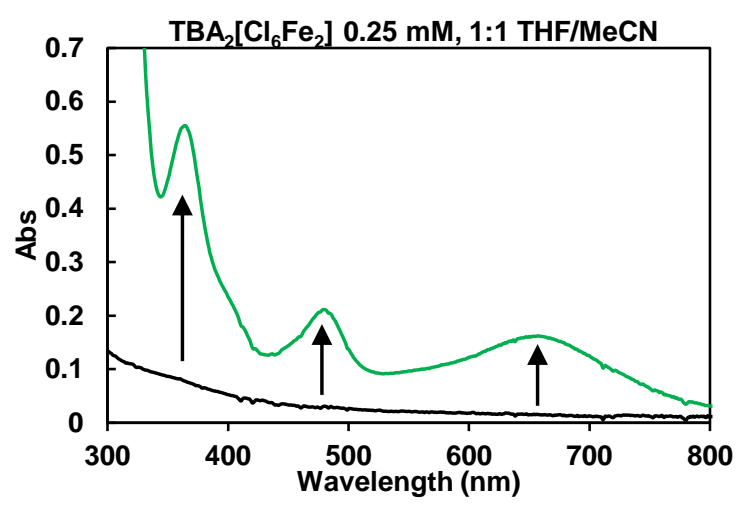

Figure S4. Reaction of $\mathrm{TBA}_{2}\left[\mathrm{Cl}_{6} \mathrm{Fe}_{2}{ }_{2}\right]$ with 5.5 eq. $\mathrm{NO}(\mathrm{g})$ to produce $\mathrm{TBA}\left[\mathrm{Cl}_{3} \mathrm{FeNO}\right](365$ $\mathrm{nm}\left(\varepsilon=1080 \mathrm{M}^{-1} \mathrm{~cm}^{-1}\right), 480 \mathrm{~nm}\left(\varepsilon=410 \mathrm{M}^{-1} \mathrm{~cm}^{-1}\right), 660 \mathrm{~nm}\left(\varepsilon=320 \mathrm{M}^{-1} \mathrm{~cm}^{-1}\right)$.

\section{Solution magnetic susceptibility measurement for $\mathrm{PPN}\left[\mathrm{Cl}_{3} \mathrm{FeNO}\right]$ with Evans method}

Under an inert atmosphere, a 50:1 mixture of $\mathrm{CDCl}_{3}$ and $\mathrm{CHCl}_{3}(0.800 \mathrm{~mL})$ was used to prepared a $0.0275 \mathrm{M}$ solution of $\mathrm{PPN}\left[\mathrm{Cl}_{3} \mathrm{FeNO}\right]$. Separately, a few drops of the $\mathrm{CDCl}_{3} / \mathrm{CHCl}_{3}$ mixture was added to a capillary tube with one end sealed, and the capillary tube was inserted into the NMR tube of the pre-made $\mathrm{PPN}\left[\mathrm{Cl}_{3} \mathrm{FeNO}\right]$ sample. $\mathrm{A}^{1} \mathrm{H}$ NMR spectrum was acquired 
(Figure S5). The magnetic susceptibility and magnetic moment were calculated and compared to theoretical values according to the equations below.

$$
\chi_{M}=\frac{3 \Delta f}{4 \pi F c}
$$

where $\chi_{M}$ is the molar magnetic susceptibility, $\Delta f$ is the peak separation (in $\mathrm{Hz}$ ) between two $\mathrm{CHCl}_{3}$ resonances from (a) the $\mathrm{CDCl}_{3} / \mathrm{CHCl}_{3}$ pure solvent mixture in the capillary tube and (b) the $\mathrm{CDCl}_{3} / \mathrm{CHCl}_{3}$ solution of paramagnetic species, $F$ is the spectrometer radiofrequency in $\mathrm{Hz}$, and $c$ is the concentration of the sample in $\mathrm{mM}$.

$$
\mu=\sqrt{8 X_{M} T}
$$

where $\mu$ is the molar magnetic susceptibility, $T$ is the temperature $(\mathrm{K})$, the constant $\sqrt{8}$ is result of $\sqrt{8}=\frac{3 k_{B}}{N \beta^{2}}\left(k_{B}\right.$ is Boltzmann's constant, $\mathrm{N}$ is Avogadro's number, $\beta$ is the Bohr magneton of the electron $\left(0.93 \times 10^{-24} \mathrm{erg} \mathrm{gauss}^{-1}\right)$.

$$
\mu_{s}=g \sqrt{s(s+1)}
$$

where $\mu_{\mathrm{s}}$ is the theoretical magnetic moment, $\mathrm{S}$ is the spin quantum number, $\mathrm{g}$ is a constant. The theoretical magnetic moment $\left(\mu_{s}=3.873\right.$ ) for systems with two unpaired electrons is in good agreement with the calculated magnetic moment for $\left[\mathrm{Cl}_{3} \mathrm{FeNO}\right]^{-}(\mu=3.936)$ (Figure S5).

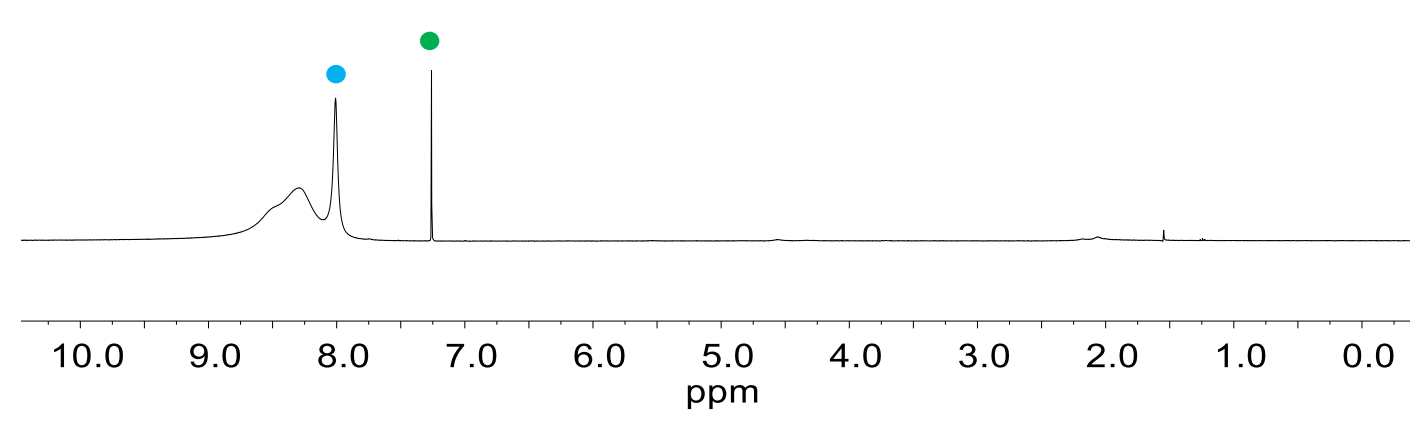

Figure S5. ${ }^{1} \mathrm{H}$ NMR $\left(\mathrm{CDCl}_{3}, 400 \mathrm{MHz}\right)$ spectrum of $\mathrm{PPN}\left[\mathrm{Cl}_{3} \mathrm{FeNO}\right]$. Green dot indicates NMR solvent $\left(\delta 7.26-\mathrm{CDCl}_{3}\right)$ in capillary; blue dot indicates solvent peak shift due to paramagnetic interaction with $\mathrm{PPN}\left[\mathrm{Cl}_{3} \mathrm{FeNO}\right](\delta$ 8.01) $(\Delta \delta=0.75 \mathrm{ppm})$. 


\section{Reaction of $\mathrm{PPN}\left[\mathrm{Cl}_{3} \mathrm{FeNO}\right]$ with $\mathrm{NaS}^{t} \mathrm{Bu}$ in THF}

In the glovebox, a suspension of $\mathrm{NaS}^{\mathrm{t}} \mathrm{Bu}(0.45 \mathrm{~mL}, 6.0 \mathrm{mM}, 2.7 \mu \mathrm{mol}, 3$ equivalents $)$ in THF was transferred to a quartz cuvette equipped with a rubber septum. Additional THF ( $2 \mathrm{~mL})$ was added to the cuvette to bring the total volume to $2.7 \mathrm{~mL}$. The cuvette was sealed and transferred to the UV-vis spectrometer. Under a nitrogen atmosphere, a solution of $\mathrm{PPN}\left[\mathrm{Cl}_{3} \mathrm{FeNO}\right](0.3 \mathrm{~mL}$, $3.0 \mathrm{mM}, 0.9 \mu \mathrm{mol})$ was injected into the cuvette to bring the final concentrations of $\mathrm{PPN}\left[\mathrm{Cl}_{3} \mathrm{FeNO}\right]$ and $\mathrm{NaS}^{t} \mathrm{Bu}$ to $0.3 \mathrm{mM}$ and $0.9 \mathrm{mM}$ (3 equiv.), respectively. The color of the solution quickly changed from green to deep red with $\lambda_{\max }$ at $360 \mathrm{~nm}$ and $475 \mathrm{~nm}$. The red species was assigned as $\left[\left({ }^{t} \mathrm{BuS}\right)_{3} \mathrm{FeNO}\right]^{-}$based on its characteristic UV-vis features. ${ }^{11}$ This insitu UV-vis experiment was repeated three more times with different amounts of $\mathrm{NaS}^{t} \mathrm{Bu}(1 \mathrm{eq}$., 2 eq., and 4 eq.). The overlay of the spectra is shown in Figure S6, left. A plot of absorbance at $475 \mathrm{~nm}$ vs. equivalents of $\mathrm{NaS}^{t} \mathrm{Bu}$ (Figure S6, right) reveals that the stoichiometry of $\mathrm{NaS}{ }^{t} \mathrm{Bu}$ : $\mathrm{PPN}\left[\mathrm{Cl}_{3} \mathrm{FeNO}\right]$ is $3: 1$, further supporting that the product of the reaction is $\left[\left({ }^{t} \mathrm{BuS}\right)_{3} \mathrm{FeNO}\right]^{-}$ reported by Lippard et al. ${ }^{11}$ Based on the reported molar extinction coefficient of $\left[\left({ }^{t} \mathrm{BuS}\right)_{3} \mathrm{FeNO}\right]^{-}$at $475 \mathrm{~nm}\left(\varepsilon=4360 \mathrm{M}^{-1} \mathrm{~cm}^{-1}\right)$, the spectroscopic yield of $\left[\left({ }^{t} \mathrm{BuS}\right)_{3} \mathrm{FeNO}\right]^{-}$is $99 \%$.
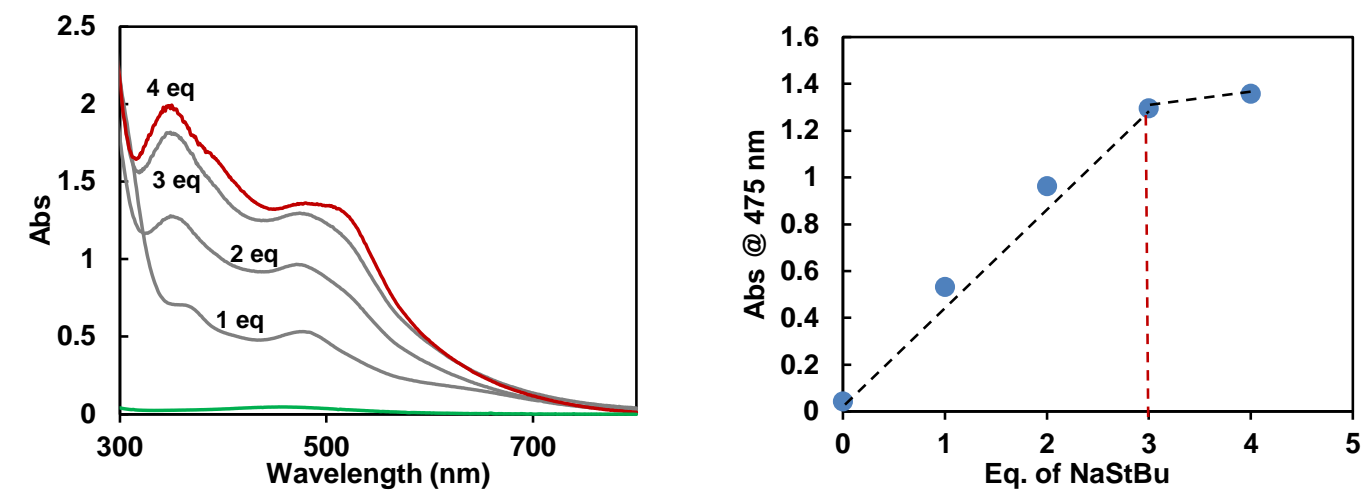

Figure S6. Left: UV-vis spectra of the reaction of $\mathrm{PPN}\left[\mathrm{Cl}_{3} \mathrm{FeNO}\right]$ (green trace) with different equivalents of $\mathrm{NaS}^{t} \mathrm{Bu}$. Right: plot of $\mathrm{Abs}\left(@ 475 \mathrm{~nm}\right.$ ) vs. equivalents of $\mathrm{NaS}^{t} \mathrm{Bu}$ added.

\section{Reaction of $\mathrm{TBA}_{2}\left[\mathrm{Cl}_{6} \mathrm{Fe}^{\mathrm{II}}{ }_{2}\right]$ with $\mathrm{Ph}_{3} \mathrm{CSNO}$ in $1: 1 \mathrm{CH}_{3} \mathrm{CN} / \mathrm{THF}$}

A solution of $\mathrm{TBA}_{2}\left[\mathrm{Cl}_{6} \mathrm{Fe}_{2}\right](2.500 \mathrm{~mL}, 0.300 \mathrm{mM}, 0.750 \mu \mathrm{mol})$ was prepared in $1: 1$ $\mathrm{CH}_{3} \mathrm{CN} / \mathrm{THF}$ and transferred into a quartz cuvette with a Schlenk attachment under a nitrogen atmosphere. The cuvette was sealed and cooled to $-50^{\circ} \mathrm{C}$ in the UV-vis spectrometer. A separate 
solution of $\mathrm{Ph}_{3} \mathrm{CSNO}(0.500 \mathrm{~mL}, 1.500 \mu \mathrm{mol}, 2$ equiv.) was made under nitrogen atmosphere and injected into the cuvette to bring the final concentration of $\mathrm{TBA}_{2}\left[\mathrm{Cl}_{6} \mathrm{Fe}_{2}\right]$ and $\mathrm{Ph}_{3} \mathrm{CSNO}$ to $0.250 \mathrm{mM}$ and $0.500 \mathrm{mM}$ ( 2 equiv.), respectively. The reaction was monitored by measuring one spectrum every 60 seconds at $-50{ }^{\circ} \mathrm{C}$ for 30 minutes (Figure $\mathrm{S} 7$, left). The reaction was then warmed to room temperature and monitored for an additional 15 hours (Figure S7, right). The calculated yield of $\mathrm{TBA}\left[\mathrm{Cl}_{3} \mathrm{FeNO}\right]$ (green trace) after decomposition was close to $100 \%$.
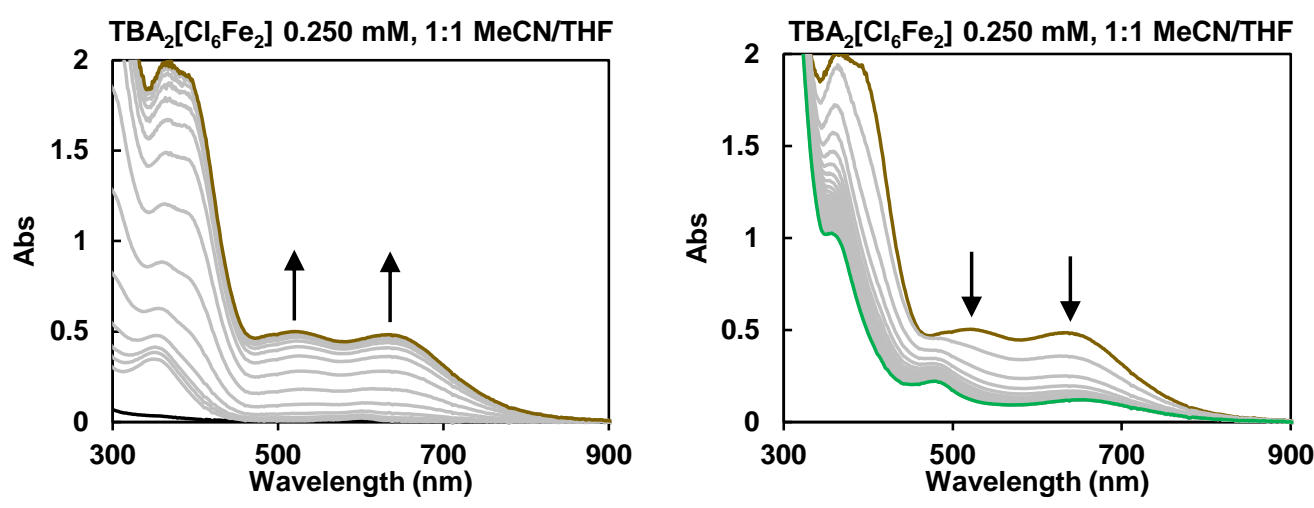

Figure S7. Left: UV-vis spectra of the reaction between $\mathrm{TBA}_{2}\left[\mathrm{Cl}_{6} \mathrm{Fe}_{2}\right]$ and $\mathrm{Ph}_{3} \mathrm{CSNO}$ to form the brown intermediate. $\left(520 \mathrm{~nm}\left(\varepsilon=999 \mathrm{M}^{-1} \mathrm{~cm}^{-1}\right), 630 \mathrm{~nm}\left(\varepsilon=966 \mathrm{M}^{-1} \mathrm{~cm}^{-1}\right)\right.$.

Right: UV-vis spetra of the decomposition of brown intermediate formed in the reaction between $\mathrm{TBA}_{2}\left[\mathrm{Cl}_{6} \mathrm{Fe}_{2}\right]$ and $\mathrm{Ph}_{3} \mathrm{CSNO}$ (brown trace) over a 15 -hour time period to form

\section{Reaction of $\mathrm{PPN}_{2}\left[\mathrm{Cl}_{6} \mathrm{Fe}^{\mathrm{II}}{ }_{2}\right]$ with $\mathrm{Ph}_{3} \mathrm{CSNO}$ in THF.}

A solution of $\mathrm{PPN}_{2}\left[\mathrm{Cl}_{6} \mathrm{Fe}_{2}\right](2.250 \mathrm{~mL}, 0.111 \mathrm{mM}, 0.250 \mu \mathrm{mol})$ was made in THF and transferred into a quartz cuvette with a Schlenk attachment under a nitrogen atmosphere. The cuvette was sealed and cooled to $-50{ }^{\circ} \mathrm{C}$ in the UV-vis spectrometer. A separate solution of $\mathrm{Ph}_{3} \mathrm{CSNO}(0.250 \mathrm{~mL}, 0.500 \mu \mathrm{mol}, 2$ equiv. $)$ was made under nitrogen atmosphere and injected into the cuvette to bring the final concentration of $\mathrm{PPN}_{2}\left[\mathrm{Cl}_{6} \mathrm{Fe}_{2}\right]$ and $\mathrm{Ph}_{3} \mathrm{CSNO}$ to $0.100 \mathrm{mM}$ and $0.200 \mathrm{mM}$ ( 2 equiv.), respectively. The reaction was monitored by measuring one UV-vis spectrum every 60 seconds for 30 minutes (Figure S8). 


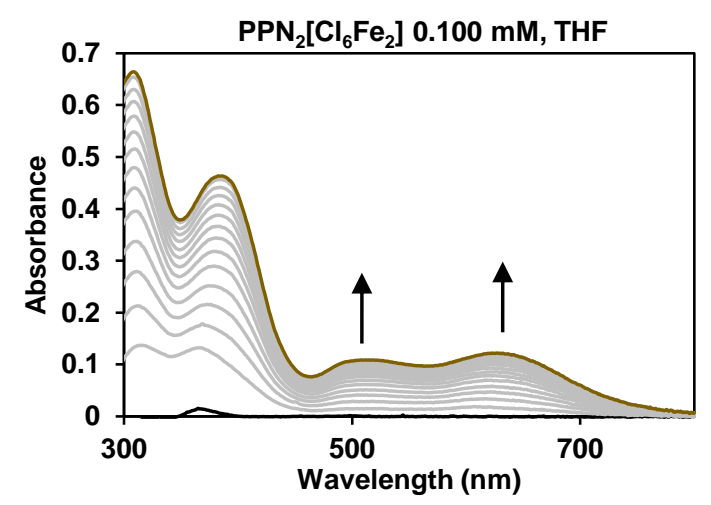

Figure S8. UV-vis spectra of the reaction between $\mathrm{PPN}_{2}\left[\mathrm{Cl}_{6} \mathrm{Fe}_{2}\right]$ and $\mathrm{Ph}_{3} \mathrm{CSNO}$.

\section{Reaction of $\mathrm{TBA}\left[\mathrm{Cl}_{4} \mathrm{Fe}^{\mathrm{III}}\right]$ with $\mathrm{NaSCPh}_{3}$ in 1:1 $\mathrm{CH}_{3} \mathrm{CN} / \mathrm{THF}$}

A solution of $\mathrm{TBA}\left[\mathrm{Cl}_{4} \mathrm{Fe}^{\mathrm{III}}\right](2.000 \mathrm{~mL}, 0.750 \mathrm{mM}, 1.5 \mu \mathrm{mol})$ was made in a solution of $1: 1$ $\mathrm{CH}_{3} \mathrm{CN} / \mathrm{THF}$ and transferred into a quartz cuvette with a Schlenk attachment under a nitrogen atmosphere. The cuvette was sealed and cooled to $-20^{\circ} \mathrm{C}$ in the UV-vis spectrometer. A separate solution of $\mathrm{NaSCPh}_{3}(1.000 \mathrm{~mL}, 1.5 \mu \mathrm{mol}, 1$ equiv.) was made under nitrogen atmosphere and injected into the cuvette under positive nitrogen flow. The UV-vis spectrum was measured 60 seconds after injection of $\mathrm{NaSCPh}_{3}$. (Figure S9)

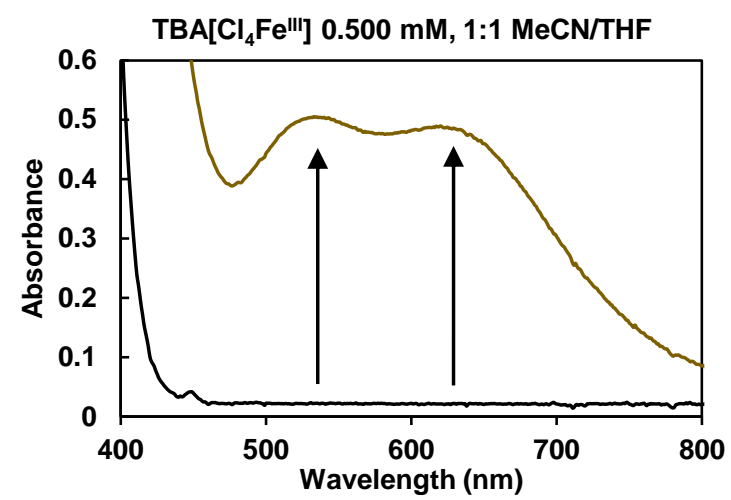

Figure S9. UV-vis spectra of the reaction between $\mathrm{TBA}\left[\mathrm{Cl}_{4} \mathrm{Fe}^{\mathrm{III}}\right]$ (black) and $\mathrm{NaSCPh}_{3}$ to form $\left[\mathrm{Cl}_{3} \mathrm{Fe}\left(\mathrm{SCPh}_{3}\right)\right]^{-}$(brown). $\left(530 \mathrm{~nm}\left(\varepsilon=958 \mathrm{M}^{-1} \mathrm{~cm}^{-1}\right), 625 \mathrm{~nm}\left(\varepsilon=924 \mathrm{M}^{-1} \mathrm{~cm}^{-1}\right)\right.$.

\section{Reaction of $\mathrm{Cl}_{3} \mathrm{Fe}^{\mathrm{III}}$ with $\mathrm{TBA}\left(\mathrm{SCPh}_{3}\right)$ in $1: 1 \mathrm{CH}_{3} \mathrm{CN} / \mathrm{THF}$}

A solution of $\mathrm{Cl}_{3} \mathrm{Fe}^{\mathrm{III}}(2.500 \mathrm{~mL}, 0.600 \mathrm{mM}, 1.5 \mu \mathrm{mol})$ was made in a solution of $1: 1$ $\mathrm{CH}_{3} \mathrm{CN} / \mathrm{THF}$ and transferred into a quartz cuvette with a Schlenk attachment under a nitrogen atmosphere. The cuvette was sealed and cooled to $-20^{\circ} \mathrm{C}$ in the UV-vis spectrometer. A separate solution of $\mathrm{TBA}\left(\mathrm{SCPh}_{3}\right)(0.500 \mathrm{~mL}, 1.5 \mu \mathrm{mol}, 1$ equiv. $)$ was made under nitrogen atmosphere 
and slowly injected into the cuvette under positive nitrogen flow $(0.100 \mathrm{~mL}$ per min to avoid formation of any $\left.\left[\mathrm{Cl}_{\mathrm{x}} \mathrm{Fe}\left(\mathrm{SCPh}_{3}\right)_{\mathrm{x}}\right]^{-}\right)$. The reaction was monitored by measuring one UV-vis spectrum every 60 seconds for 30 minutes. (Figure S10).

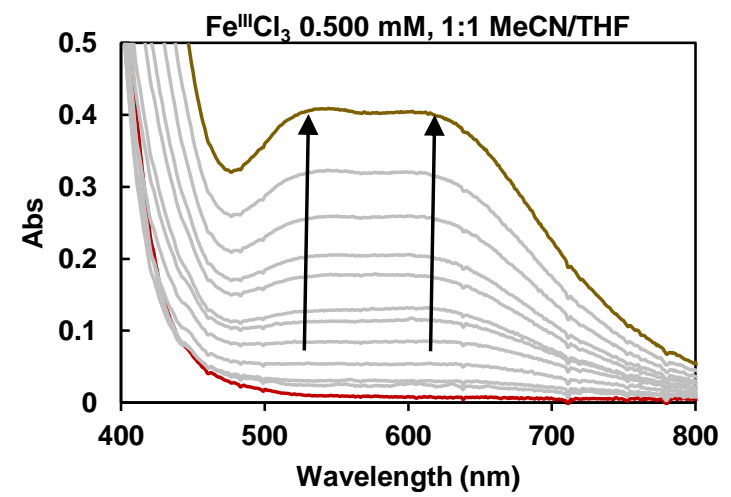

Figure S10. UV-vis spectra of the reaction between $\mathrm{Fe}^{\mathrm{III}} \mathrm{Cl}_{3}$ (red) and $\mathrm{TBA}\left(\mathrm{SCPh}_{3}\right)$ to form $\left[\mathrm{Cl}_{3} \mathrm{Fe}\left(\mathrm{SCPh}_{3}\right)\right]^{-}$(brown).

\section{Determining the stoichiometry of $\mathrm{NaSCPh}_{3}$ to $\mathrm{TBA}\left[\mathrm{Cl}_{4} \mathrm{Fe}^{\mathrm{III}}\right]$ with $\mathrm{UV}$-vis titration.}

In glovebox, an acetonitrile solution of $\mathrm{TBA}\left[\mathrm{Cl}_{4} \mathrm{Fe}^{\mathrm{III}}\right](2.500 \mathrm{~mL}, 0.600 \mathrm{mM}, 1.5 \mu \mathrm{mol})$ was transferred to a quartz cuvette equipped with a septum. The cuvette was sealed and cooled to $-35^{\circ} \mathrm{C}$ in the UV-vis spectrometer. The reaction mixture was titrated with sequential additions of acetonitrile solution of $\mathrm{TBA}\left(\mathrm{SCPh}_{3}\right)(0.100 \mathrm{~mL}, 0.75 \mu \mathrm{mol}, 1$ eq each aliquot $)$. The progress of the reaction was monitored by measuring one UV-vis spectrum every 60 seconds until the spectrum stabilized (Figure S11). A plot of absorbance at $540 \mathrm{~nm}$ and $628 \mathrm{~nm}$ vs. equivalents of $\mathrm{NaSCPh}_{3}$ (Figure $\mathrm{S} 11$ bottom) suggests that the $\mathrm{Fe}^{\mathrm{III}}$ center can bind up to four equivalents of thiolates. ${ }^{12,13}$ This provides evidence for the $\left[\mathrm{Cl}_{3} \mathrm{Fe}^{\mathrm{III}}\left(\mathrm{SCPh}_{3}\right)\right]^{-}$species undergoing chloride thiolate ligand scrambling, as described in Scheme S1 (below). The $\lambda_{\max }$ of the iron-thiolate charge transfer features $(450-650 \mathrm{~nm})$ shifts with higher concentrations of $\mathrm{TBA}\left(\mathrm{SCPh}_{3}\right)$ increase, suggesting the existence of multiple $\left[\mathrm{Cl}_{x} \mathrm{Fe}^{\mathrm{III}}\left(\mathrm{SCPh}_{3}\right)_{4-\mathrm{x}}\right]^{-}$species in solution. 

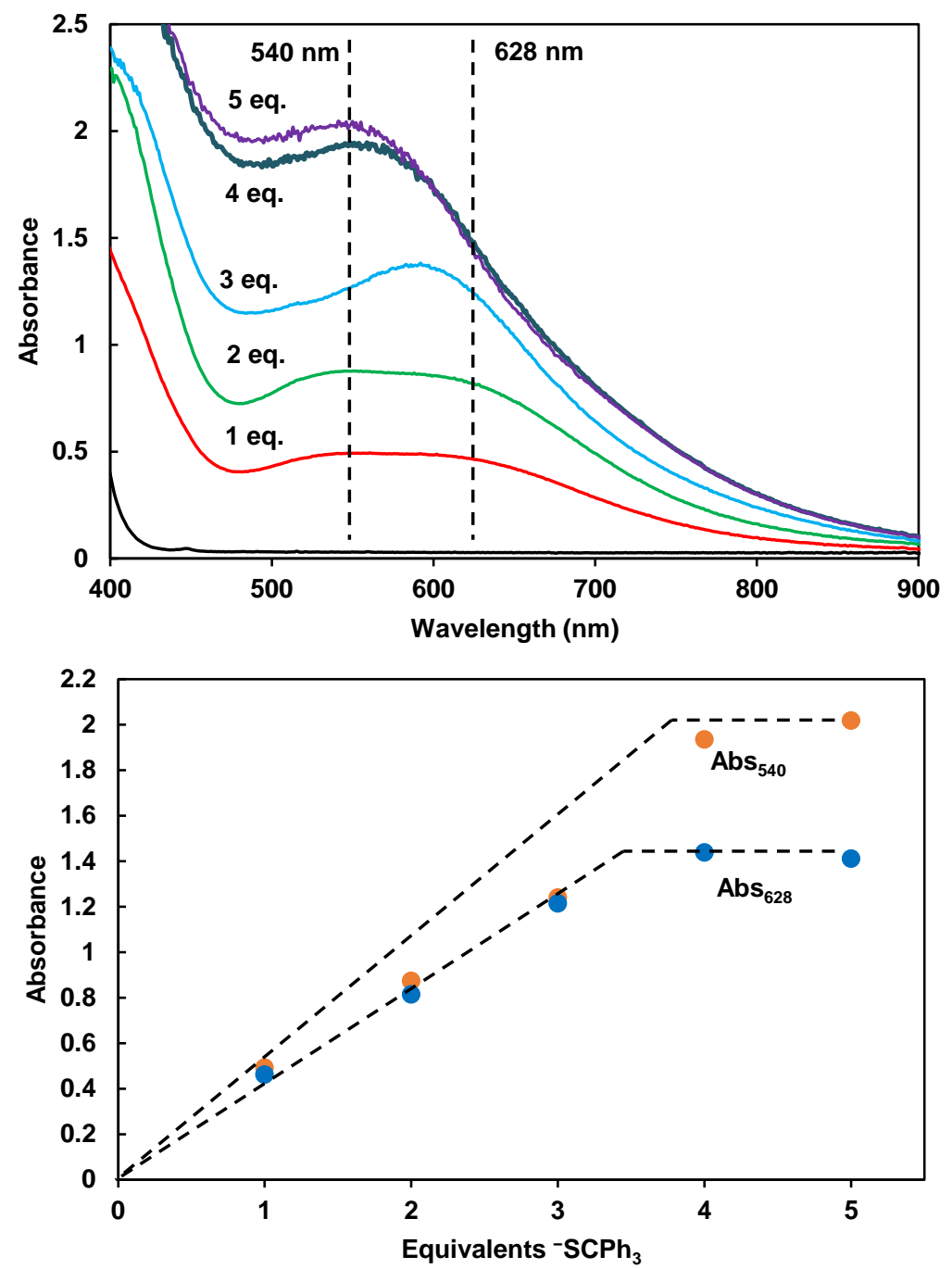

Figure S11. Top: UV-vis spectra of the reaction between $\mathrm{TBA}\left[\mathrm{Cl}_{4} \mathrm{Fe}^{\mathrm{III}}\right]$ with different equivalents of $\mathrm{NaSCPh}_{3}\left(1-5\right.$ equivalents) at $-35{ }^{\circ} \mathrm{C}$ in acetonitrile. All spectra were normalized by considering dilution introduced by each aliquot of $\mathrm{NaSCPh}_{3}$. Bottom: plot of absorbance at $540 \mathrm{~nm}$ and $628 \mathrm{~nm} v s$. equivalents of $\mathrm{NaSCPh}_{3}$ added.

\section{Determining the stoichiometry of $\mathrm{TBA}\left(\mathrm{SCPh}_{3}\right)$ to $\mathrm{Cl}_{3} \mathrm{Fe}^{\mathrm{III}}$ with $\mathrm{UV}$-vis titration.}

In a glovebox, an acetonitrile solution of $\mathrm{Cl}_{3} \mathrm{Fe}^{\mathrm{III}}(2.500 \mathrm{~mL}, 0.600 \mathrm{mM}, 1.5 \mu \mathrm{mol})$ was transferred to a quartz cuvette equipped with a septum. The cuvette was sealed and cooled to $-35^{\circ} \mathrm{C}$ in the UV-vis spectrometer. A separate solution of $\mathrm{TBA}\left(\mathrm{SCPh}_{3}\right)$ (acetonitrile, $0.500 \mathrm{~mL}$, $1.5 \mu \mathrm{mol}, 1 \mathrm{eq})$ was made under nitrogen atmosphere and injected into the cuvette. The color of the solution changed from orange to brown with $\lambda_{\max }$ at $540 \mathrm{~nm}$ and a broad shoulder at 628 $\mathrm{nm}$, which was assigned to $\left[\mathrm{Cl}_{3} \mathrm{Fe}^{\mathrm{III}}\left(\mathrm{SCPh}_{3}\right)\right]^{-}$. The reaction mixture was titrated with sequential addition of acetonitrile solution of $\mathrm{TBA}\left(\mathrm{SCPh}_{3}\right)(0.250 \mathrm{~mL}, 0.75 \mu \mathrm{mol}, 0.5$ eq each aliquot). 
The progress of the reaction was monitored by measuring one UV-vis spectrum every 30 seconds until the spectrum stabilized (Figure S10). A plot of absorbance at $540 \mathrm{~nm}$ and $628 \mathrm{~nm}$ vs. equivalents of $\mathrm{TBA}\left(\mathrm{SCPh}_{3}\right)$ (Figure $\mathrm{SX}$ bottom) suggests that the $\mathrm{Fe}^{\mathrm{III}}$ center can bind up to four equivalents of thiolates.

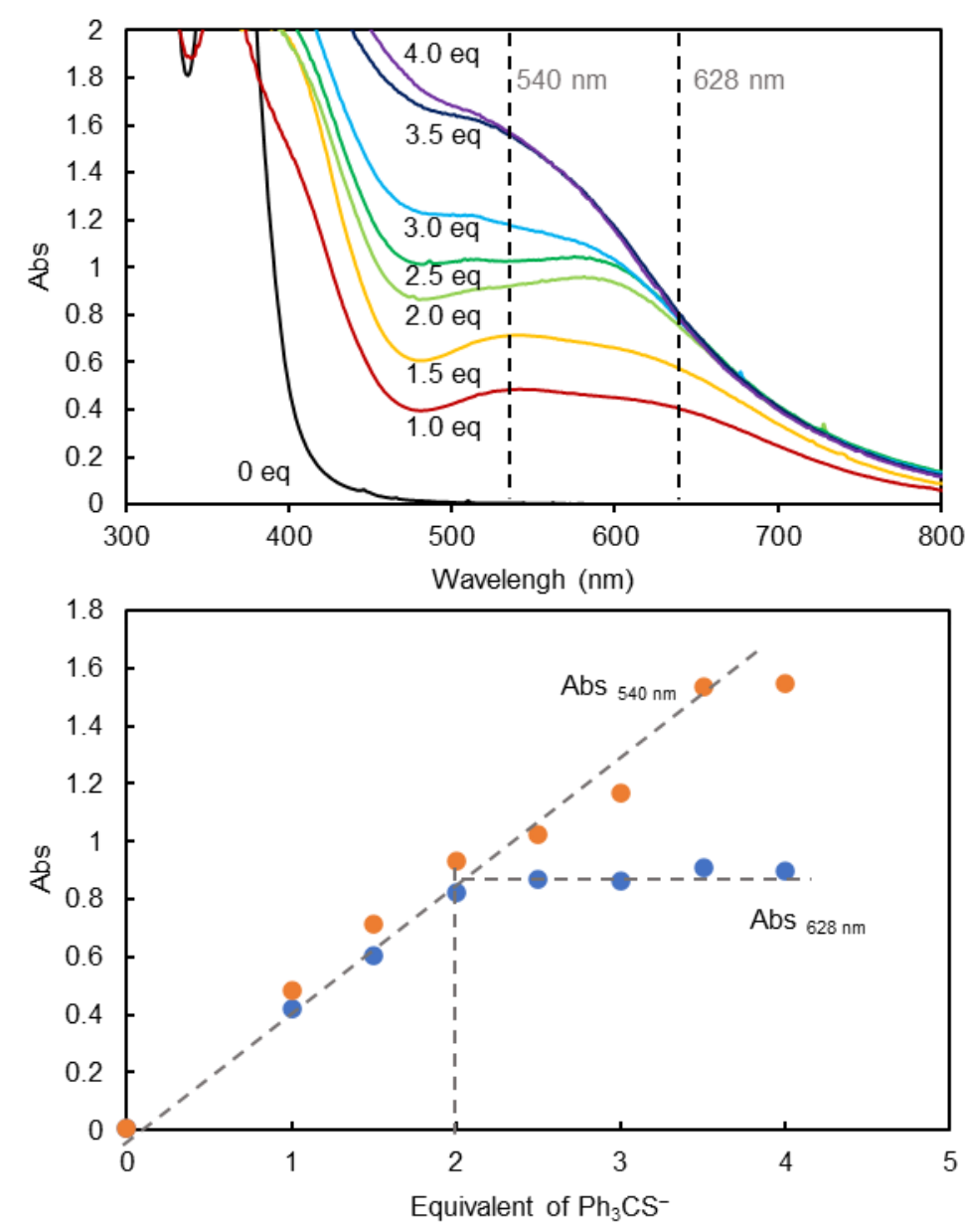

Figure S12. Top: UV-vis spectra of the reaction between $\mathrm{Cl}_{3} \mathrm{Fe}^{\mathrm{III}}$ with different equivalents of $\mathrm{TBA}\left(\mathrm{SCPh}_{3}\right)\left(1-4\right.$ equivalents) at $-35^{\circ} \mathrm{C}$ in acetonitrile. All spectra were normalized by considering dilution introduced by each aliquot of $\mathrm{TBA}\left(\mathrm{SCPh}_{3}\right)$. Bottom: plot of absorbance at $540 \mathrm{~nm}$ and $628 \mathrm{~nm} v s$. equivalent of $\mathrm{TBA}\left(\mathrm{SCPh}_{3}\right)$ added.

\section{Scheme S1.}

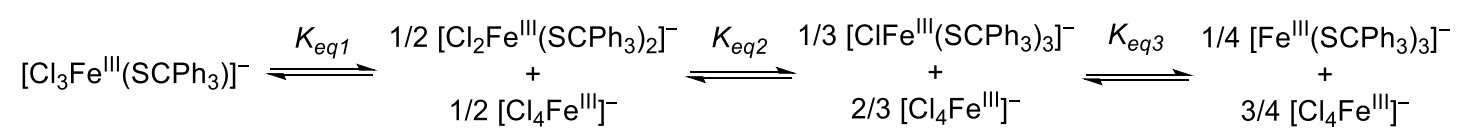

\section{Quantification of $\mathrm{Ph}_{3} \mathrm{CS}-\mathrm{SCPh}_{3}$ and $\left[\mathrm{Cl}_{6} \mathrm{Fe}^{\mathrm{II}}{ }_{2}\right]^{2-}$ from $\mathrm{Fe}^{\mathrm{III}} \mathrm{Cl}_{3}+1$ eq. $\mathrm{TBA}\left(\mathrm{SCPh}_{3}\right)$}

In the glovebox, separate solutions of $\mathrm{Fe}^{\mathrm{III}} \mathrm{Cl}_{3}(9.73 \mathrm{mg}, 0.060 \mathrm{mmol}, 1$ eq. $)$ and $\mathrm{TBA}\left(\mathrm{SCPh}_{3}\right)$ ( $31.1 \mathrm{mg}, 0.060 \mathrm{mmol}, 1$ eq.) were made in $\mathrm{MeCN}$. The solutions were cooled to $-35^{\circ} \mathrm{C}$, then 
combined and left to react at $-35^{\circ} \mathrm{C}$ until the brown color of the reaction had faded (48 hours). The MeCN was removed in vacuo and toluene was added to the solid to dissolve the disulfide that had formed. The mixture was filtered to collect the toluene filtrate, and the insoluble portion containing $\mathrm{TBA}_{2}\left[\mathrm{Cl}_{6} \mathrm{Fe}_{2}{ }_{2}\right]$ was recrystallized from acetone/diethyl ether. The disulfide was recrystallized from toluene/diethyl ether. The yields of disulfide and $\mathrm{TBA}_{2}\left[\mathrm{Cl}_{6} \mathrm{Fe}_{2}{ }_{2}\right]$ were $73.3 \%$ (12.1 mg) and $82.7 \%(20.1 \mathrm{mg})$, respectively.

\section{Synthesis and characterization of $\mathrm{TBA}_{2}\left[\mathrm{Cl}_{6}{ }^{57} \mathrm{Fe}^{\mathrm{II}}{ }_{2}\right]$ for Mössbauer spectroscopy}

This compound was prepared according to a similar procedure to the unlabeled material. Under ambient air, an acetone solution of TBACl $(27.4 \mathrm{mg}, 98.6 \mu \mathrm{mol})$ was added to a stirring $2 \mathrm{~mL}$ suspension of an acetone solution of $>95 \%$ enriched ${ }^{57} \mathrm{Fe}^{\mathrm{II}} \mathrm{Cl}_{2}^{5}$ (12.6 mg, $\left.98.6 \mu \mathrm{mol}\right)$. Upon addition of $\mathrm{TBACl}$, the mixture became homogenous and a golden yellow. The solution was stirred overnight to give a pale yellow precipitate and a yellow solution. The solution was filtered through Celite and the precipitate was washed with acetone $(3 \times 2 \mathrm{~mL})$. After concentration of the filtrate in vacuo, diethyl ether (ca. $3 \mathrm{~mL}$ ) was added and the vial placed in a $-35{ }^{\circ} \mathrm{C}$ freezer. The colorless crystals were collected after workup correspond to $\mathrm{TBA}_{2}\left[\mathrm{Cl}_{6}{ }^{57} \mathrm{Fe}^{\mathrm{II}}{ }_{2}\right]$ (20.3 mg, $50.8 \%$, based on $\mathrm{Fe}$ ). Successful synthesis of this material was confirmed by UV-vis monitoring of the reaction of $\mathrm{TBA}_{2}\left[\mathrm{Cl}_{6}{ }^{57} \mathrm{Fe}^{\mathrm{II}} 2\right]$ with $\mathrm{Ph}_{3} \mathrm{CSNO}$. A solution of $\mathrm{TBA}_{2}\left[\mathrm{Cl}_{6} \mathrm{Fe}_{2}\right](2.500 \mathrm{~mL}, 0.300 \mathrm{mM}, 0.750 \mu \mathrm{mol})$ was prepared in $1: 1 \mathrm{CH}_{3} \mathrm{CN} / \mathrm{THF}$ and transferred into a quartz cuvette with a Schlenk attachment under a nitrogen atmosphere. The cuvette was sealed and cooled to $-50{ }^{\circ} \mathrm{C}$ in the UV-vis spectrometer. A separate solution of $\mathrm{Ph}_{3} \mathrm{CSNO}(0.500 \mathrm{~mL}, 1.500 \mu \mathrm{mol}, 2$ equiv. $)$ was made under nitrogen atmosphere and injected into the cuvette to bring the final concentration of $\mathrm{TBA}_{2}\left[\mathrm{Cl}_{6} \mathrm{Fe}_{2}\right]$ and $\mathrm{Ph}_{3} \mathrm{CSNO}$ to $0.250 \mathrm{mM}$ and that of $0.500 \mathrm{mM}$ ( 2 equiv.), respectively. The reaction was monitored by measuring one UV-vis spectrum every 60 seconds at $-50{ }^{\circ} \mathrm{C}$ for 30 minutes (Figure S13). 


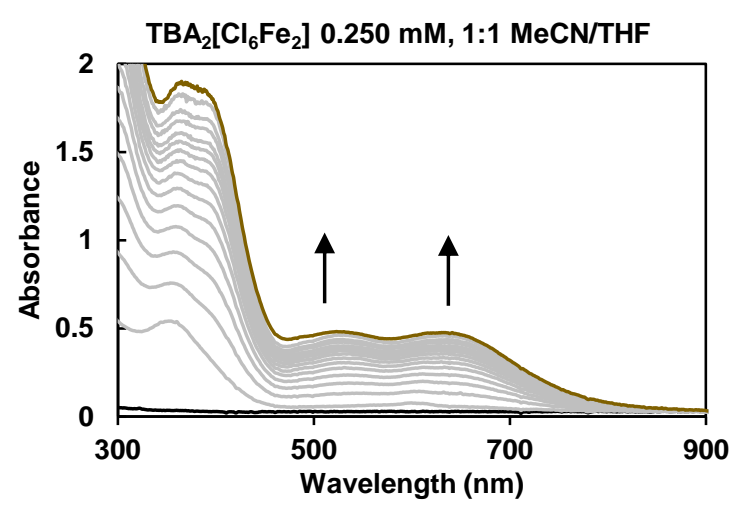

Figure S13. UV-vis spectra of the reaction between $\mathrm{TBA}_{2}\left[\mathrm{Cl}_{6}{ }^{57} \mathrm{Fe}^{\mathrm{II}}{ }_{2}\right]$ (black) and $\mathrm{Ph}_{3} \mathrm{CSNO}$ to form the brown intermediate. The absorption values at 520 and $630 \mathrm{~nm}$ were in agreement with those formed by the unlabeled material.

\section{Solution Mössbauer of $\mathrm{TBA}_{2}\left[\mathrm{Cl}_{6}{ }^{57} \mathrm{Fe}^{\mathrm{II}}\right]$}

To a delrin Mössbauer sample cup containing $1.4 \mathrm{mg}$ of $\mathrm{TBA}_{2}\left[\mathrm{Cl}_{6}{ }^{57} \mathrm{Fe}^{\mathrm{II}}\right]$ under a nitrogen atmosphere at room temperature was added $0.345 \mathrm{~mL}$ of 9:1 THF/MeCN to form a $5 \mathrm{mM}$ solution. The sample was sealed in a vial, removed from the glovebox and frozen in liquid nitrogen. The sample was kept stored in liquid nitrogen until being loaded. The data was collected at $80 \mathrm{~K}$ in the absence of an applied external magnetic field (Figure S14).

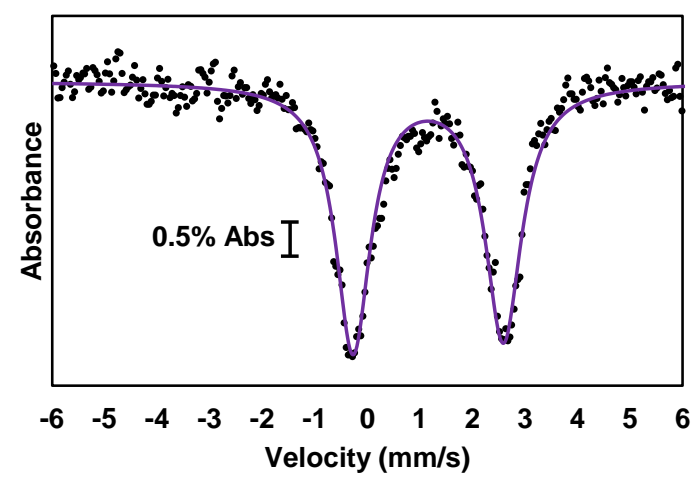

Figure S14. ${ }^{57} \mathrm{Fe}$ Mössbauer spectrum of $\mathrm{TBA}_{2}\left[\mathrm{Cl}_{6}{ }^{57} \mathrm{Fe}^{\mathrm{II}}{ }_{2}\right](80 \mathrm{~K}, 0 \mathrm{~T})$. Experimenal data (black dots), best fit (purple) $\left(\chi^{2}=0.698\right) . \delta=1.16 \mathrm{~mm} \mathrm{~s}^{-1},\left|\Delta \mathrm{E}_{\mathrm{Q}}\right|=2.86 \mathrm{~mm} \mathrm{~s}^{-1}, \Gamma_{\mathrm{L}}=0.80$, $\Gamma_{\mathrm{R}}=0.84$.

\section{Synthesis and characterization of $\left.\mathrm{TBA}_{[\mathrm{Cl}}{ }^{57} \mathrm{Fe}^{\mathrm{III}}\right]$ for Mössbauer spectroscopy}

$\mathrm{TBA}\left[\mathrm{Cl}_{4}{ }^{57} \mathrm{Fe}^{\mathrm{III}}\right]$ was prepared according to modified literature procedures. ${ }^{6,14}$ To $29.0 \mathrm{mg}$ of

${ }^{57} \mathrm{Fe}$ powder (>95\%) $(0.510 \mathrm{mmol}, 1 \mathrm{eq})$ was added $5 \mathrm{~mL}$ of concentrated $(35 \%)$ aqueous $\mathrm{HCl}$. This solution was heated to $120{ }^{\circ} \mathrm{C}$ and refluxed for $48 \mathrm{hrs}$, during which time an orange solution $\left(\mathrm{Fe}^{\mathrm{III}} \mathrm{Cl}_{3} \bullet 6 \mathrm{H}_{2} \mathrm{O}\right)$ formed. Upon cooling to room temperature, one equivalent of TBACl 
(0.510 mmol, $141.5 \mathrm{mg}$ ) was added to the solution with stirring. Immediately, a yellow precipitate formed. The yellow precipitate was collected by filtration, and rinsed with diethyl ether. The yellow precipitate was recrystallized from a mixture of dichloromethane/diethyl ether at $-35{ }^{\circ} \mathrm{C}$ to yield $\mathrm{TBA}\left[\mathrm{Cl}_{4}{ }^{57} \mathrm{Fe}^{\mathrm{III}}\right](85.2 \mathrm{mg}, 38.0 \%$ based off $\mathrm{Fe})$. The formation of $\mathrm{TBA}\left[\mathrm{Cl}_{4}{ }^{57} \mathrm{Fe}^{\mathrm{III}}\right]$ was verified by monitoring the reaction with $\mathrm{NaSCPh}_{3}$ by $\mathrm{UV}$-vis spectroscopy. A solution of $\mathrm{TBA}\left[\mathrm{Cl}_{4} \mathrm{Fe}^{\mathrm{III}}\right](2.000 \mathrm{~mL}, 0.750 \mathrm{mM}, 1.5 \mu \mathrm{mol})$ was made in a solution of $1: 1$ $\mathrm{CH}_{3} \mathrm{CN} / \mathrm{THF}$ and transferred into a quartz cuvette with a Schlenk attachment under a nitrogen atmosphere. The cuvette was sealed and cooled to $-20^{\circ} \mathrm{C}$ in the UV-vis spectrometer. A separate solution of $\mathrm{NaSCPh}_{3}(1.000 \mathrm{~mL}, 1.5 \mu \mathrm{mol}, 1$ equiv.) was made under nitrogen atmosphere and injected into the cuvette under positive nitrogen flow. The UV-vis spectrum was measured 60 seconds after injection of $\mathrm{NaSCPh}_{3}$ (Figure S15)

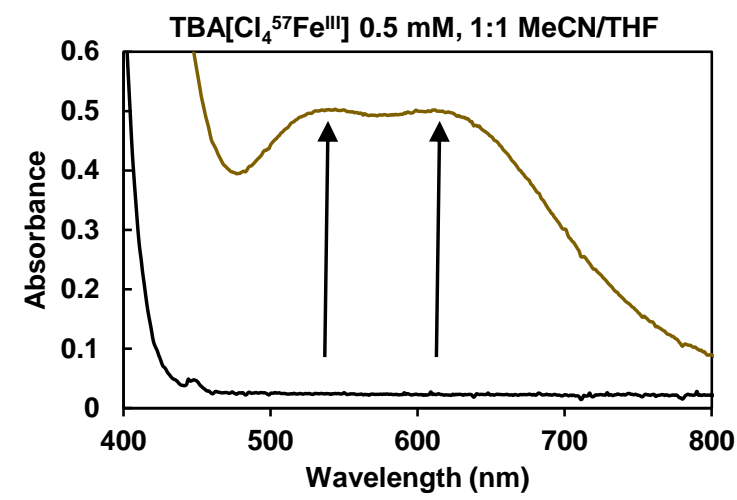

Figure S15. UV-vis spectra of the reaction between $\mathrm{TBA}\left[\mathrm{Cl}_{4}{ }^{57} \mathrm{Fe}^{\mathrm{III}}\right]$ (black) and $\mathrm{NaSCPh}_{3}$ to form $\mathrm{TBA}\left[\mathrm{Cl}_{3}{ }^{57} \mathrm{Fe}-\mathrm{SCPh}_{3}\right]$. The absorption values at 540 and $628 \mathrm{~nm}$ were in agreement with those formed by the unlabeled material. 


\section{Solution Mössbauer of $\mathrm{TBA}\left[\mathrm{Cl}_{4}{ }^{57} \mathrm{Fe}^{\mathrm{III}}\right]$}

To a delrin Mössbauer sample cup containing $2.1 \mathrm{mg}$ of $\mathrm{TBA}\left[\mathrm{Cl}_{4}{ }^{57} \mathrm{Fe}^{\mathrm{III}}\right]$ under a nitrogen atmosphere at room temperature was added $475.6 \mu \mathrm{L}$ of 9:1 THF/MeCN to form a $10 \mathrm{mM}$ solution. The sample was sealed in a vial, removed from the glovebox and frozen in liquid nitrogen. The sample was kept stored in liquid nitrogen until being loaded. The data was collected at $80 \mathrm{~K}$ in the absence of an applied external magnetic field (Figure S17).

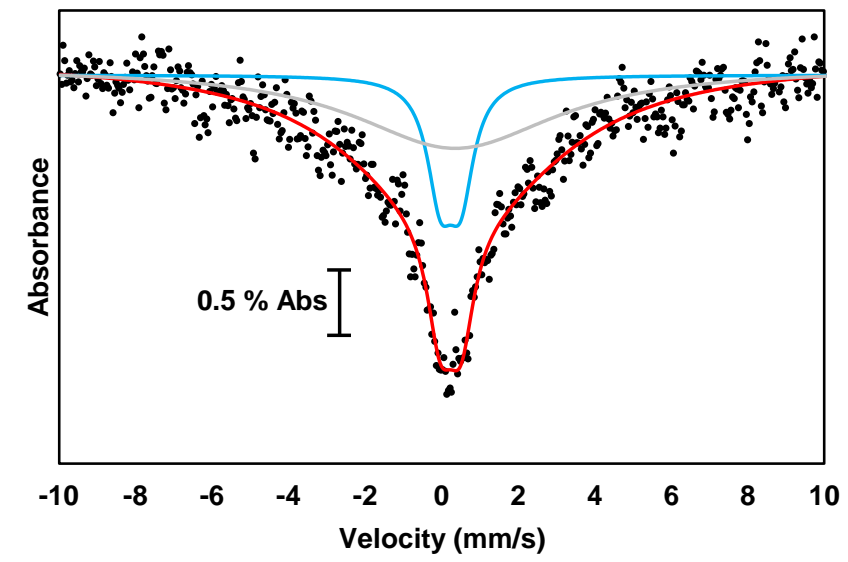

Figure S17. ${ }^{57} \mathrm{Fe}$ Mössbauer spectrum of TBA $\left[\mathrm{Cl}_{4}{ }^{57} \mathrm{Fe}^{\mathrm{III}}\right](80 \mathrm{~K}, 0 \mathrm{~T})$. Experimenal data (black dots), best fit (red) $\left(\chi^{2}=0.553\right)$. The best fit was comprised of two subsites. Subsite 1 (blue) $\delta=0.23 \mathrm{~mm} \mathrm{~s}^{-1},\left|\Delta \mathrm{E}_{\mathrm{Q}}\right|=0.53 \mathrm{~mm} \mathrm{~s}^{-1}, \Gamma_{\mathrm{L}}=\Gamma_{\mathrm{R}}=0.83$. Subsite 2 (grey) was added to represent the intermediate relaxation of the doublet at $80 \mathrm{~K} . \delta=0.36 \mathrm{~mm} \mathrm{~s}^{-1},\left|\Delta \mathrm{E}_{\mathrm{Q}}\right|=$ $0.00 \mathrm{~mm} \mathrm{~s}^{-1}, \Gamma_{\mathrm{L}}=\Gamma_{\mathrm{R}}=6.51$

\section{Solution Mössbauer of the reaction of $\mathrm{TBA}_{2}\left[\mathrm{Cl}_{6}{ }^{57} \mathrm{Fe}^{\mathrm{II}}{ }_{2}\right]+2 \mathrm{Ph}_{3} \mathrm{CSNO}$}

Under a nitrogen atmosphere, a solution of $\mathrm{Ph}_{3} \mathrm{CSNO}(30 \mathrm{mM}, 0.250 \mathrm{~mL})$ in 9:1 THF/CH${ }_{3} \mathrm{CN}$ was cooled to $-45{ }^{\circ} \mathrm{C}$ in a delrin Mössbauer sample cup. Separately, a solution of $\mathrm{TBA}_{2}\left[\mathrm{Cl}_{6}{ }^{57} \mathrm{Fe}^{\mathrm{II}}{ }_{2}\right](15 \mathrm{mM}, 0.250 \mathrm{~mL})$ was cooled to $-45^{\circ} \mathrm{C}$. The two solutions were mixed to make the final concentration of $\mathrm{Fe}$ and $\mathrm{Ph}_{3} \mathrm{CSNO} 15 \mathrm{mM}$. Upon mixing, there was a gradual color change from green to dark brown. After allowing the reaction to proceed for 60 mins, the solvent was removed to form a thin layer of sample in the bottom of the sample cup. The sample was then frozen in liquid nitrogen and kept stored under liquid nitrogen until loading to avoid $\mathrm{O}_{2}$ and moisture contamination. Mössbauer spectra were collected at $80 \mathrm{~K}$ in the absence of an 
external magnetic field (Figure S18).

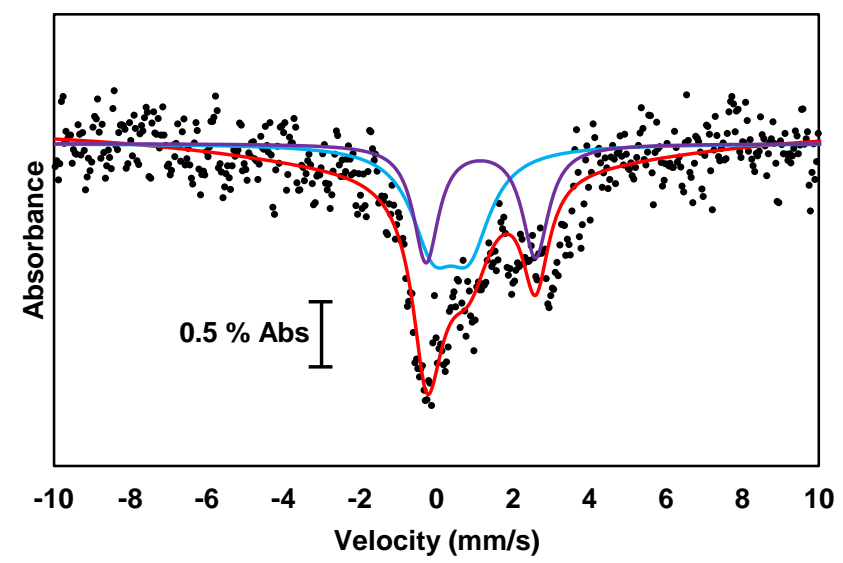

Figure S18. ${ }^{57} \mathrm{Fe}$ Mössbauer spectrum of $\mathrm{TBA}_{2}\left[\mathrm{Cl}_{6}{ }^{57} \mathrm{Fe}^{\mathrm{II}}{ }_{2}\right]+2$ eq. $\mathrm{Ph}_{3} \mathrm{CSNO}(80 \mathrm{~K}, 0 \mathrm{~T})$. Experimenal data (black dots), best fit (red) $\left(\chi^{2}=0.694\right)$ with parameters: subsite 1 (blue) matches the parameters for $\left[\mathrm{Cl}_{3} \mathrm{Fe}^{\mathrm{III}}-\mathrm{SCPh}_{3}\right]^{-}$independently generated from the reaction of TBA $\left[\mathrm{Cl}_{4} \mathrm{Fe}^{\mathrm{III}}\right]+1 \mathrm{NaSCPh}_{3}, \delta=0.38 \mathrm{~mm} \mathrm{~s}^{-1},\left|\Delta \mathrm{E}_{\mathrm{Q}}\right|=0.94 \mathrm{~mm} \mathrm{~s}^{-1}, \Gamma_{\mathrm{R}}=\Gamma_{\mathrm{L}}=1.38, \% \mathrm{I}=$ 56 ; subsite 2 (purple) matches the parameters of $\mathrm{TBA}_{2}\left[\mathrm{Cl}_{6}{ }^{57} \mathrm{Fe}^{\mathrm{II}}{ }_{2}\right] \delta=1.16 \mathrm{~mm} \mathrm{~s}^{-1},\left|\Delta \mathrm{E}_{\mathrm{Q}}\right|=$ $2.86 \mathrm{~mm} \mathrm{~s}^{-1}, \Gamma_{\mathrm{R}}=0.84 \Gamma_{\mathrm{L}}=0.80, \% \mathrm{I}=44$.

\section{Solution Mössbauer of the reaction of $\mathrm{TBA}\left[\mathrm{Cl}_{4}{ }^{57} \mathrm{Fe}^{\mathrm{III}}\right]+1 \mathrm{NaSCPh}_{3}$}

Under a nitrogen atmosphere, a solution of $\mathrm{NaSCPh}_{3}(20 \mathrm{mM}, 0.250 \mathrm{~mL})$ in 9:1 THF/CH $\mathrm{CH}_{3} \mathrm{CN}$ was cooled to $-20{ }^{\circ} \mathrm{C}$ in a delrin Mössbauer sample cup. Separately, a solution of TBA $\left[\mathrm{Cl}_{4}{ }^{57} \mathrm{Fe}^{\mathrm{III}}\right]$ (20 mM, $0.250 \mathrm{~mL}$ ) was cooled to $-20{ }^{\circ} \mathrm{C}$. The two solutions were mixed to make the final concentration of $\mathrm{Fe}$ and $\mathrm{NaSCPh}_{3} 10 \mathrm{mM}$. Upon mixing, there was a color change from yellow to dark brown. After allowing the reaction to occur for ten minutes, solvent was removed to form a thin layer of sample at the bottom of the sample cup. The sample cup then was frozen in liquid nitrogen and kept stored under liquid nitrogen until loading to avoid $\mathrm{O}_{2}$ and moisture contamination. Mössbauer spectra were collected at $80 \mathrm{~K}$ in the absence of an external magnetic field (Figure S19). 


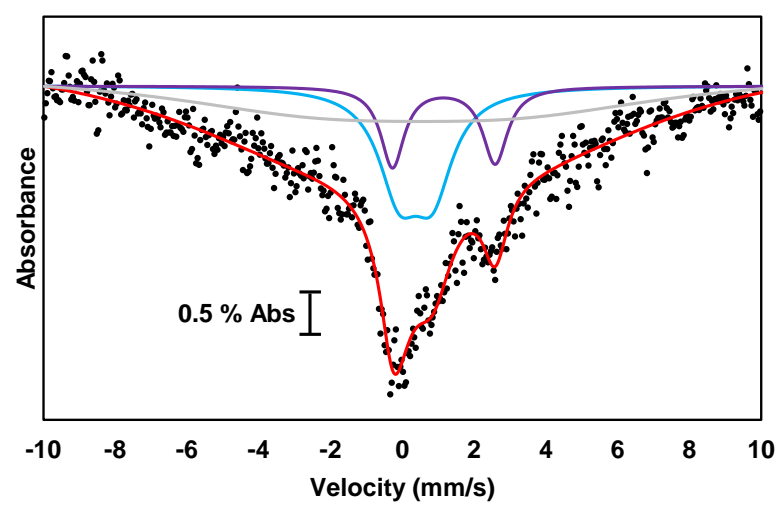

Figure S19. ${ }^{57} \mathrm{Fe}$ Mössbauer spectrum of TBA $\left[\mathrm{Cl}_{4}{ }^{57} \mathrm{Fe}^{\mathrm{III}}\right]+1$ eq. $\mathrm{NaSCPh}_{3}(80 \mathrm{~K}, 0 \mathrm{~T})$. Experimenal data (black dots), best fit (red) $\left(\chi^{2}=0.634\right)$ with parameters: subsite 1 (blue) $\delta=0.38 \mathrm{~mm} \mathrm{~s}^{-1},\left|\Delta \mathrm{E}_{\mathrm{Q}}\right|=0.93 \mathrm{~mm} \mathrm{~s}^{-1}, \Gamma_{\mathrm{R}}=\Gamma_{\mathrm{L}}=1.38, \% \mathrm{I}=67$; subsite 2 (purple) matches the parameters of $\mathrm{TBA}_{2}\left[\mathrm{Cl}_{6}{ }^{57} \mathrm{Fe}^{\mathrm{II}}{ }_{2}\right] \delta=1.16 \mathrm{~mm} \mathrm{~s}^{-1},\left|\Delta \mathrm{E}_{\mathrm{Q}}\right|=2.86 \mathrm{~mm} \mathrm{~s}^{-1}, \Gamma_{\mathrm{R}}=0.84 \Gamma_{\mathrm{L}}=$ $0.80, \% \mathrm{I}=33$. Subsite 3 (grey) was added to represent the intermediate relaxation of the doublet at $80 \mathrm{~K} . \delta=0.45 \mathrm{~mm} \mathrm{~s}^{-1},\left|\Delta \mathrm{E}_{\mathrm{Q}}\right|=5.61 \mathrm{~mm} \mathrm{~s}^{-1}, \Gamma_{\mathrm{L}}=\Gamma_{\mathrm{R}}=10.78$

\section{In situ solution IR monitoring of $\mathrm{TBA}_{2}\left[\mathrm{Cl}_{6} \mathrm{Fe}^{\mathrm{II}}{ }_{2}\right]+2$ eq. $\mathrm{Ph}_{3} \mathrm{CSNO}$ in THF-d8}

A solution of $\mathrm{Ph}_{3} \mathrm{CSNO}(1.000 \mathrm{~mL}, 150.0 \mathrm{mM}, 150.0 \mu \mathrm{mol})$ was made in THF- $d_{8}$ under nitrogen atmosphere. The solution was injected with a syringe into a three-neck cell under flowing argon atmosphere and cooled in an acetone/dry ice bath to $-78^{\circ} \mathrm{C}$. A separate solution of $\mathrm{TBA}_{2}\left[\mathrm{Cl}_{6} \mathrm{Fe}^{\mathrm{II}}{ }_{2}\right](1.500 \mathrm{~mL}, 75 \mu \mathrm{mol}, 0.5$ equiv.) was made under nitrogen atmosphere and injected via syringe into the cell to make the final concentration of $\mathrm{Ph}_{3} \mathrm{CSNO}$ and $\mathrm{Fe} 30 \mathrm{mM}$. The reaction was monitored by scanning the IR spectrum every 15 seconds for a total of $3 \mathrm{hrs}$ (Figure S20) 


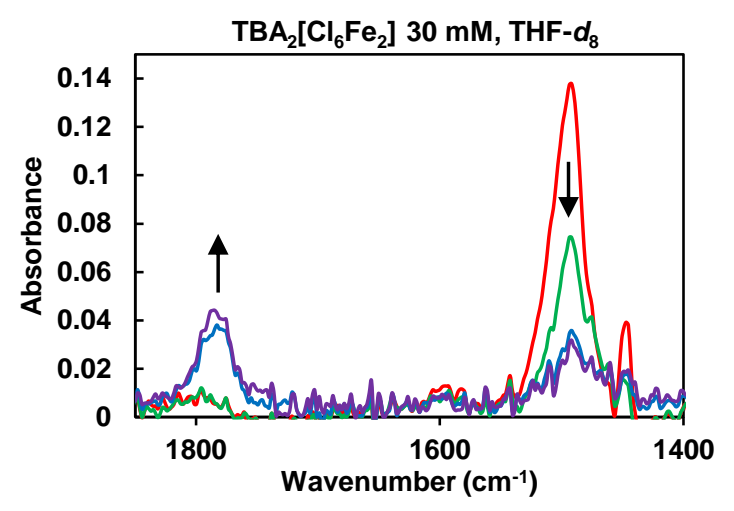

Figure S20. IR spectra (solvent background subtracted) of the reaction between $\mathrm{TBA}_{2}\left[\mathrm{Cl}_{6} \mathrm{Fe}^{\mathrm{II}}{ }_{2}\right]$ and 2 eq. $\mathrm{Ph}_{3} \mathrm{CSNO}$. Red trace: $\mathrm{Ph}_{3} \mathrm{CSNO}$ in $1.000 \mathrm{~mL}$ THF- $d_{8}$ at $-78{ }^{\circ} \mathrm{C}$. Green: directly after addition of $\mathrm{TBA}_{2}\left[\mathrm{Cl}_{6} \mathrm{Fe}^{\mathrm{II}}{ }_{2}\right]$ in $1.500 \mathrm{~mL}$ THF- $d_{8}$ at $-78{ }^{\circ} \mathrm{C}$. Dark blue: After 1 hour of reaction, gradually warming solution to $0{ }^{\circ} \mathrm{C}$. Purple: completed reaction after 3 hours. $v(\mathrm{NO})_{\mathrm{Ph} 3 S \mathrm{NO}}=1493 \mathrm{~cm}^{-1} ; v(\mathrm{NO})_{\mathrm{TBA}[\mathrm{Cl} 3 \mathrm{FeNO}]}=1792 \mathrm{~cm}^{-1}$.

\section{In situ solution IR monitoring of $\mathrm{TBA}_{2}\left[\mathrm{Cl}_{6} \mathrm{Fe}^{\mathrm{II}}{ }_{2}\right]+2 \mathrm{Ph}_{3} \mathrm{CS}^{15} \mathrm{NO}$ in THF-d8}

A solution of $\mathrm{Ph}_{3} \mathrm{CS}^{15} \mathrm{NO}(1.500 \mathrm{~mL}, 80.0 \mathrm{mM}, 120.0 \mu \mathrm{mol})$ was made in THF- $d_{8}$ under nitrogen atmosphere. The solution was injected with a syringe into a three-neck cell under flowing argon atmosphere and cooled in an acetone/dry ice bath to $-78^{\circ} \mathrm{C}$. A separate solution of $\mathrm{TBA}_{2}\left[\mathrm{Cl}_{6} \mathrm{Fe}^{\mathrm{II}}{ }_{2}\right](0.500 \mathrm{~mL}, 60 \mu \mathrm{mol}, 0.5$ equiv.) was made under nitrogen atmosphere and injected via syringe into the cell to make the final concentration of $\mathrm{Ph}_{3} \mathrm{CS}^{15} \mathrm{NO}$ and $\mathrm{Fe} 30 \mathrm{mM}$. The reaction was monitored by scanning the IR spectrum every 15 seconds for a total of $3 \mathrm{hrs}$ (Figure S21). $v\left({ }^{15} \mathrm{NO}\right)_{\mathrm{Ph} 3 \mathrm{~S} 15 \mathrm{NO}}=1473 \mathrm{~cm}^{-1} ; \Delta v=21 \mathrm{~cm}^{-1}$ (calculated from Hooke's law $\Delta v=27$ $\left.\mathrm{cm}^{-1}\right) v\left({ }^{15} \mathrm{NO}\right)_{\mathrm{TBA}[\mathrm{Cl} 3 \mathrm{Fe} 15 \mathrm{NO}]}=1753 \mathrm{~cm}^{-1} ; \Delta v=39 \mathrm{~cm}^{-1}$ (calculated from Hooke's law $\Delta v=33$ $\left.\mathrm{cm}^{-1}\right)$. 


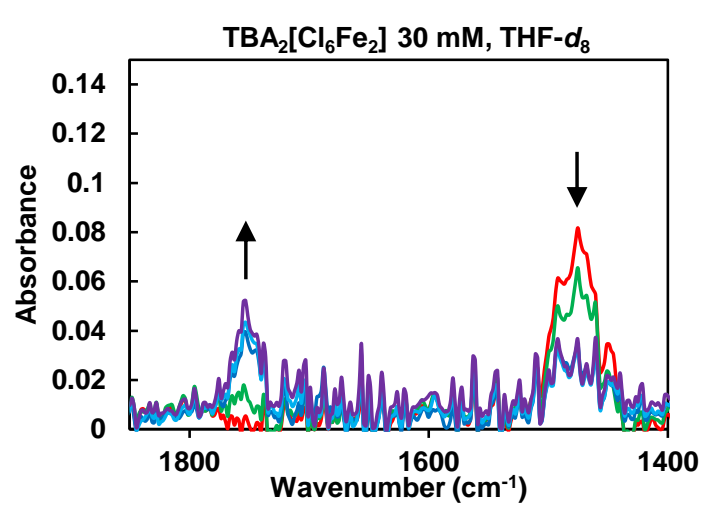

Figure S21. IR spectra (solvent background subtracted) of the reaction between $\mathrm{TBA}_{2}\left[\mathrm{Cl}_{6} \mathrm{Fe}_{2}^{\mathrm{II}}\right]$ and 2 eq. $\mathrm{Ph}_{3} \mathrm{CS}^{15} \mathrm{NO}$. Red trace: $\mathrm{Ph}_{3} \mathrm{CS}^{15} \mathrm{NO}$ in $1.5 \mathrm{~mL}$ THF- $d_{8}$ at $-78{ }^{\circ} \mathrm{C}$. Green: directly after addition of $\mathrm{TBA}_{2}\left[\mathrm{Cl}_{6} \mathrm{Fe}_{2}{ }_{2}\right]$ in $0.5 \mathrm{~mL}$ THF- $d_{8}$ at $-78{ }^{\circ} \mathrm{C}$. Dark blue: After 1 hour of reaction, gradually warming solution to $0{ }^{\circ} \mathrm{C}$. Light blue: After 1 hour 45 minutes of reaction, solution at room temperature. Purple: completed reaction after 3 hours.

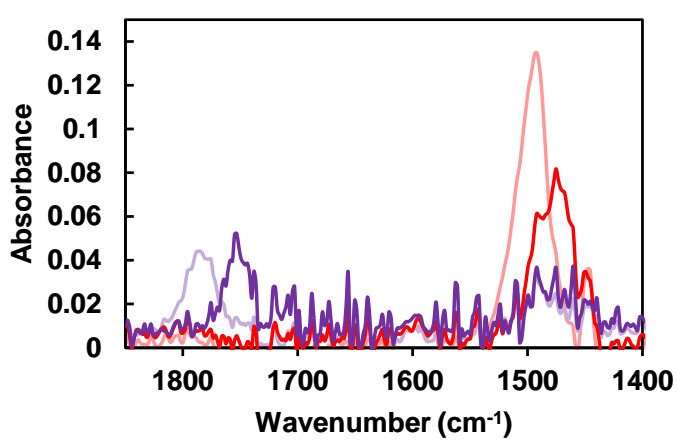

Figure S22. Overlaid IR spectra of the reaction between $\mathrm{TBA}_{2}\left[\mathrm{Cl}_{6} \mathrm{Fe}_{2}{ }_{2}\right]$ with 2 eq. $\mathrm{Ph}_{3} \mathrm{CS}^{15} \mathrm{NO}$ (bright traces), and $\mathrm{TBA}_{2}\left[\mathrm{Cl}_{6} \mathrm{Fe}_{2}{ }_{2}\right]$ and 2 eq. $\mathrm{Ph}_{3} \mathrm{CS}^{14} \mathrm{NO}$ (pale traces). The red and purple traces in both cases correspond to the beginning and end of the reactions, respectively.

\section{In situ solution IR of $\mathrm{Cl}_{3} \mathrm{Fe}^{\mathrm{III}}+\mathrm{TBA}\left(\mathrm{SCPh}_{3}\right)$ and $\mathrm{NO}(\mathrm{g})$ in 9:1 $\mathrm{THF}-d_{8} / \mathrm{CD}_{3} \mathrm{CN}$}

A solution of $\mathrm{Fe}^{\mathrm{III}} \mathrm{Cl}_{3}(1.250 \mathrm{~mL}, 60.0 \mathrm{mM}, 75.0 \mu \mathrm{mol})$ was made in $9: 1 \mathrm{THF}-d_{8} / \mathrm{CD}_{3} \mathrm{CN}$ under a nitrogen atmosphere. The solution was injected with a syringe into a three-neck cell under flowing nitrogen atmosphere and cooled in an acetone/dry ice bath to $-78{ }^{\circ} \mathrm{C}$. A separate solution of $\mathrm{TBA}\left(\mathrm{SCPh}_{3}\right)(1.250 \mathrm{~mL}, 75.0 \mu \mathrm{mol})$ was made under nitrogen atmosphere and injected via syringe into the cell to make the final concentration of $\mathrm{Fe} / \mathrm{SCPh}_{3} 30 \mathrm{mM}$. Gaseous $\mathrm{NO}^{\bullet} 2 \times 1.8 \mathrm{~mL}$ ( 1 eq. each) was added sequentially, allowing sufficient time for the spectrum to stabilize between additions. The reaction was monitored for 2 hours by scanning the IR 
spectrum every 15 seconds.

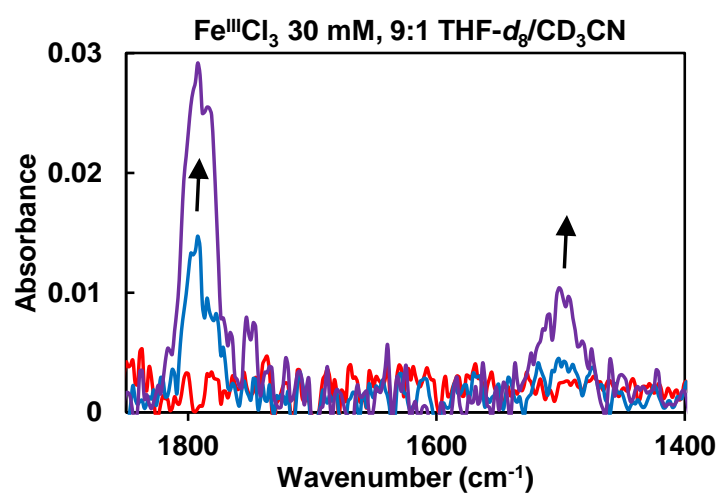

Figure S23. IR spectra (solvent background subtracted) of the reaction between $\mathrm{Fe}^{\mathrm{III}} \mathrm{Cl}_{3}, 1$ eq. $\mathrm{TBA}\left(\mathrm{SCPh}_{3}\right)$, and 2 eq. $\mathrm{NO}(\mathrm{g})$. Red: $\mathrm{Fe}^{\mathrm{III}} \mathrm{Cl}_{3} / \mathrm{TBA}\left(\mathrm{SCPh}_{3}\right)$ solution in $2.500 \mathrm{~mL}$ 9:1 THF- $d_{8} / \mathrm{CD}_{3} \mathrm{CN}$ at $-78{ }^{\circ} \mathrm{C}$. Blue: directly after addition of the second eq. $\mathrm{NO}(\mathrm{g})$ at $-78{ }^{\circ} \mathrm{C}$. Purple: reaction solution after 2 hours, at $-50{ }^{\circ} \mathrm{C}$. The spectrum did not change after warming the solution to room temperature. $v(\mathrm{NO})_{\mathrm{TBA}[\mathrm{Cl} 3 \mathrm{FeNO}]}=1792 \mathrm{~cm}^{-1} ; v(\mathrm{NO})_{\mathrm{Ph} 3 \mathrm{CSNO}}=$ $1493 \mathrm{~cm}^{-1}$.

\section{In situ solution IR calibration curve for $\mathrm{TBA}\left[\mathrm{Cl}_{3} \mathrm{FeNO}\right]$ in 9:1 $\mathrm{THF}-d_{8} / \mathrm{CD}_{3} \mathrm{CN}$}

A solution of $\mathrm{TBA}_{2}\left[\mathrm{Cl}_{6} \mathrm{Fe}_{2}{ }_{2}\right](0.250 \mathrm{~mL}, 15.0 \mathrm{mM}, 3.750 \mu \mathrm{mol})$ was made in 9:1 THF$d_{8} / \mathrm{CD}_{3} \mathrm{CN}$ under a nitrogen atmosphere. The solution was injected into a three-neck cell with a syringe under flowing nitrogen atmosphere and cooled in an acetone/dry ice bath to $-78{ }^{\circ} \mathrm{C}$. Gaseous NO$\left(0.18 \mathrm{~mL}, 7.500 \mu \mathrm{mol}, 2\right.$ eq.) was added to form $\mathrm{TBA}\left[\mathrm{Cl}_{3} \mathrm{FeNO}\right]$ in-situ at a 30 $\mathrm{mM}$ concentration. Following formation of $\mathrm{TBA}\left[\mathrm{Cl}_{3} \mathrm{FeNO}\right]$, additional solvent was added in $0.10 \mathrm{~mL}$ increments $(0.60 \mathrm{~mL}$ added total $)$ allowing sufficient time for the spectrum to stabilize between additions (Figure SX, left). The absorbance at $1792 \mathrm{~cm}^{-1}$ was tracked after each addition to create a calibration curve (Figure S24 right). The yield of $\mathrm{TBA}\left[\mathrm{Cl}_{3} \mathrm{FeNO}\right]$ from the reaction of $\mathrm{Fe}^{\mathrm{III}} \mathrm{Cl}_{3}, \mathrm{TBA}\left(\mathrm{SCPh}_{3}\right)$, and $\mathrm{NO}^{*}$ was calculated to be $20.2 \mathrm{mM} \pm 0.6 \mathrm{mM}$, based on the absorbance at $1792 \mathrm{~cm}^{-1}$ (Figure S24) 

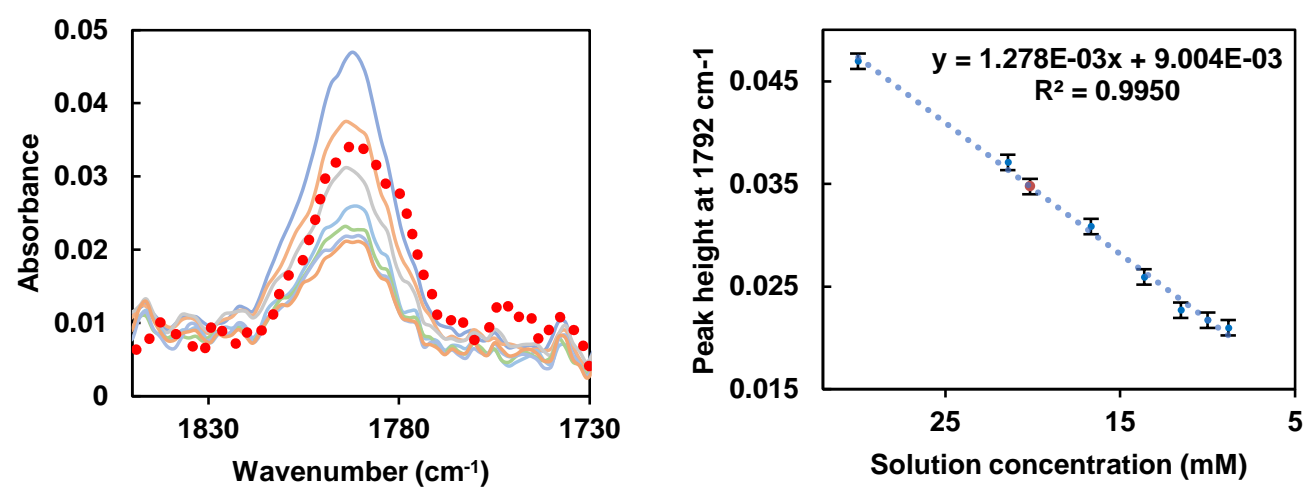

Figure S24. Left: IR spectra (solvent background subtracted) of TBA $\left[\mathrm{Cl}_{3} \mathrm{FeNO}\right]$ at $-78{ }^{\circ} \mathrm{C}$. Each solid trace represents the dilution that occurred after each $0.10 \mathrm{~mL}$ addition of solvent. Red dotted trace: overlay of $\mathrm{TBA}\left[\mathrm{Cl}_{3} \mathrm{FeNO}\right]$ peak from the final spectrum in figure S23. Right: Calibration curve (error bars \pm 1 std.dev y-direction) for TBA $\left[\mathrm{Cl}_{3} \mathrm{FeNO}\right]$ (blue dots) with equation and $\mathrm{R}^{2}$ value. Red dot represents the calculated yield of $\mathrm{TBA}\left[\mathrm{Cl}_{3} \mathrm{FeNO}\right]$.

\section{In situ solution IR calibration curve for $\mathrm{Ph}_{3} \mathrm{CSNO}$ in 9:1 THF- $d_{8} / \mathrm{CD}_{3} \mathrm{CN}$}

A solution of $\mathrm{Ph}_{3} \mathrm{CSNO}(0.250 \mathrm{~mL}, 30.0 \mathrm{mM}, 7.500 \mu \mathrm{mol})$ was made in 9:1 THF- $d_{8} / \mathrm{CD}_{3} \mathrm{CN}$ under a nitrogen atmosphere. The solution was injected with a syringe into a three-neck flask under flowing nitrogen atmosphere and cooled with an acetone/dry ice bath to $-78{ }^{\circ} \mathrm{C}$. Additional solvent was added in $0.10 \mathrm{~mL}$ increments $(0.60 \mathrm{~mL}$ added total $)$ allowing sufficient time for the spectrum to stabilize between additions (Figure S25, left). The absorbance was tracked at $1493 \mathrm{~cm}^{-1}$ after each addition to create the calibration curve (Figure S25, right). The absorbance at $1493 \mathrm{~cm}^{-1}$ from the independent reaction between $\mathrm{Fe}^{\mathrm{III}} \mathrm{Cl}_{3}$ and $\mathrm{TBA}\left(\mathrm{SCPh}_{3}\right)$ was
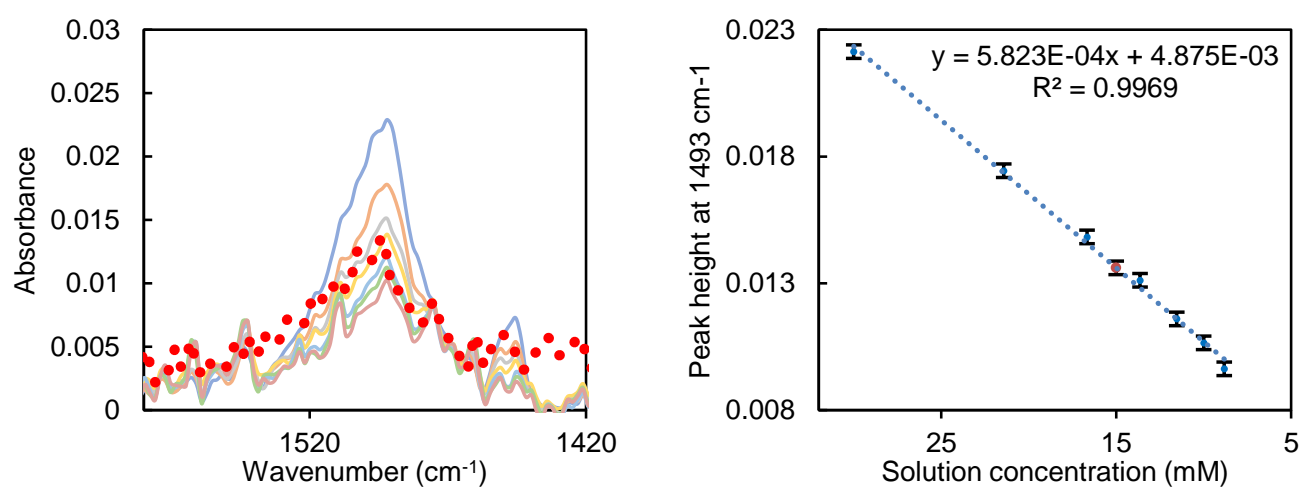

Figure S25. Left: IR spectra (solvent background subtracted) of $\mathrm{Ph}_{3} \mathrm{CSNO}$ at $-78{ }^{\circ} \mathrm{C}$. Each solid trace represents the dilution that occurred after each $0.10 \mathrm{~mL}$ addition of solvent. Red dotted trace: overlay of $\mathrm{Ph}_{3} \mathrm{CSNO}$ peak from the final spectrum in figure S23. Right: Calibration curve (error bars \pm 1 std.dev y-direction) for $\mathrm{Ph}_{3} \mathrm{CSNO}$ (blue dots) with equation and $\mathrm{R}^{2}$ value. Red dot represents the calculated yield of $\mathrm{Ph}_{3} \mathrm{CSNO}$. 
utilized to calculate the yield of $\mathrm{Ph}_{3} \mathrm{CSNO}$. The yield was calculated to be $15.0 \mathrm{mM} \pm 0.5 \mathrm{mM}$.

\section{X-ray Crystallographic Data}

Single crystals of each compound were mounted under paratone oil on glass fibers and immediately placed under a cold nitrogen stream (Oxford Cryosystems Cryostream) at 150(2) K on a Bruker D8 with Mo K $\alpha$ radiation source $(\lambda=0.7107 \AA)$ and a Photon II detector. The data was integrated with the Bruker SAINT program. Structure solutions were performed using the SHELXTL/PC suite ${ }^{15}$ under XSEED ${ }^{16}$ or Olex2 program, and were corrected for Lorentz and polarization effects. An empirical absorption correction was applied using Blessing's method as incorporated into the program SADABS. ${ }^{17}$ Non-hydrogen atoms were refined with anisotropic thermal parameters and hydrogen atoms were included in idealized positions. Structures were rendered with POV-Ray in XSEED using 50\% probability ellipsoids.

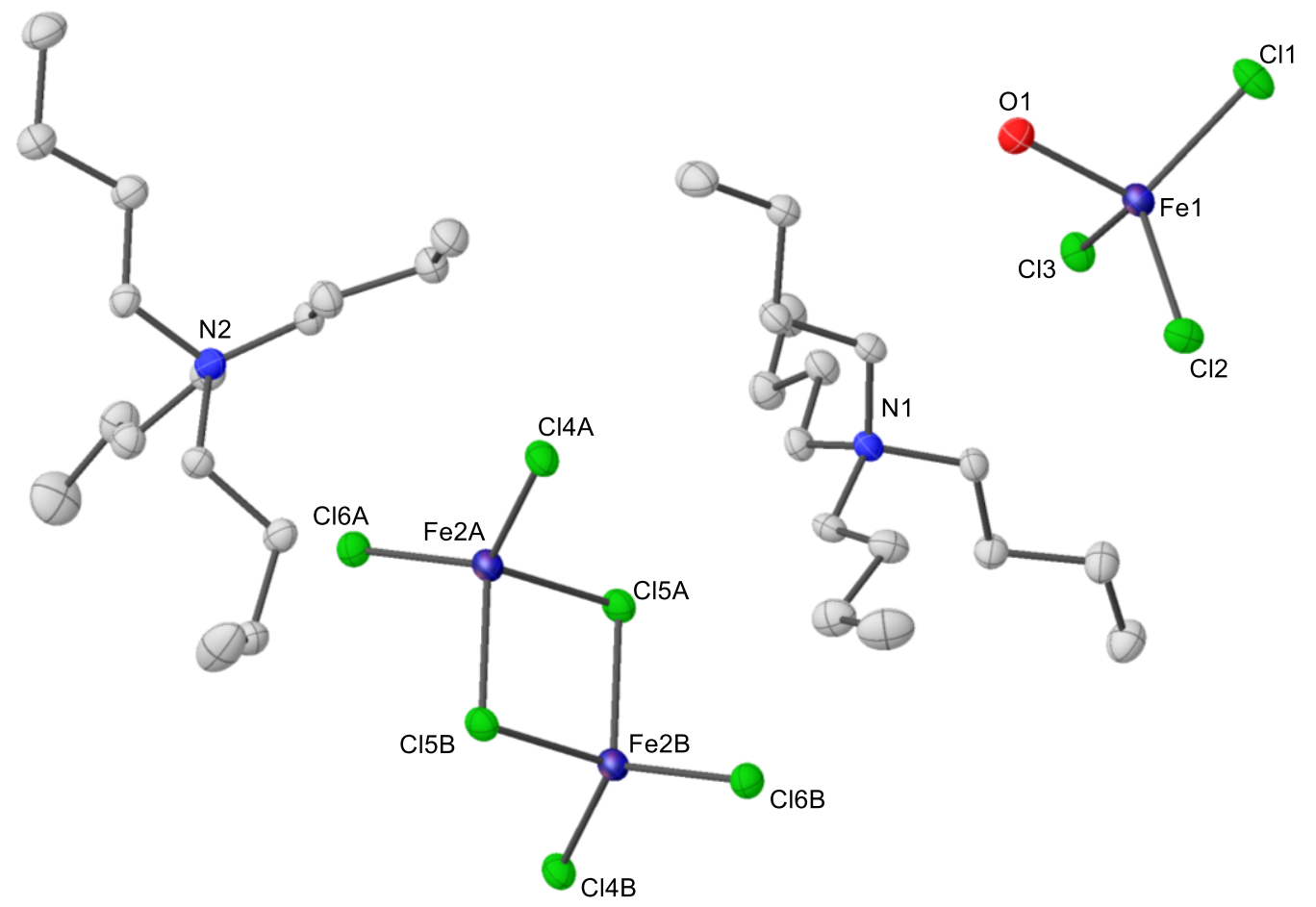

Figure S26. X-ray structure of $\mathrm{TBA}_{3}\left[\mathrm{Cl}_{6} \mathrm{Fe}^{\mathrm{II}}{ }_{2}\right] \cdot\left[\mathrm{Cl}_{3} \mathrm{Fe}^{\mathrm{II}}\left(\mathrm{H}_{2} \mathrm{O}\right)\right]$ with thermal ellipsoids of $30 \%$ probability. $\mathrm{An} \mathrm{Et}_{2} \mathrm{O}$ solvent molecule is omitted. Only $1 / 2\left[\mathrm{Cl}_{6} \mathrm{Fe}_{2}{ }_{2}\right]^{2-}$ is contained in the unit cell, however, the full dimeric structure is shown for clarity, with the two $\left[\mathrm{Cl}_{3} \mathrm{Fe}^{\mathrm{II}}\right]^{-}$sites denoted $\mathrm{A}$ and $\mathrm{B}$. 


\section{Computational Methodology}

All computations were performed using Gaussian16 or ORCA 4.1.0. ${ }^{18}$ The initial geometry optimization for the ground states of $\left[\mathrm{Cl}_{3} \mathrm{FeNO}\right]^{-}$and $\left[\mathrm{Cl}_{3} \mathrm{CuNO}\right]^{-}$were carried out using the (U)BP86 ${ }^{19,20}$ method with the def2-TZVP basis set, starting from coordinates obtained from the single crystal structures. ${ }^{21}$ The initial geometry optimization for $\mathrm{Cl}_{3} \mathrm{FeNO}$ in the $S=0,1,2$ spin states was performed using the (U)BP86 $6^{19,20}$, (U)B3LYP ${ }^{19}$, and TPSSh ${ }^{22}$ functionals and def2TZVPP basis set, although further calculations were carried out with the optimized geometry obtained from the TPSSh/def2-TZVP optimization. Coordinates of optimized compounds along with their energies (in Hartree) are reported. All geometry optimizations were performed using tight convergence thresholds for the energy $\left(10^{-6} \mathrm{E}_{\mathrm{h}}\right)$ and maximum value of the energy nuclear gradient $\left(3 \times 10^{-4} \mathrm{E}_{\mathrm{h}} / \mathrm{a}_{0}\right){ }^{23}$. Multireference calculations were performed using the complete active space self-consistent field (CASSCF) method. ${ }^{24,25}$ In all CASSCF computations, the def2-TZVP basis set was used. For the initial reference CASSCF wavefunction of $\left[\mathrm{Cl}_{3} \mathrm{FeNO}\right]^{-}$ an active space of 9 electrons in 13 orbitals was used, for $\left[\mathrm{Cl}_{3} \mathrm{CuNO}\right]^{-}$, an active space of 10 electrons in 13 orbitals, and $\mathrm{Cl}_{3} \mathrm{FeNO}$, an active space of 6 electrons in 13 orbitals. After CASSCF computations, a valence-bond like interpretation of the wavefunction was performed on each complex to qualitatively determine the contributions of different resonance structures, i.e. $\mathrm{Fe}(\mathrm{III})-\mathrm{NO}^{-}, \mathrm{Fe}(\mathrm{II})-\mathrm{NO}^{*}$. To this end, a localization of the CASSCF natural orbitals was done, followed by a CAS-CI expansion of the wavefunction. Only CSF's with a coefficient larger than 0.01 were included in these analyses, which reproduced about $95 \%$ of the total CAS wavefunction in each case. The localization procedure (using the Cholesky algorithm) ${ }^{26}$ was only performed on orbitals with a significant contribution from both $\mathrm{NO}$ and the metal. In most cases this was the combination of metal $3 \mathrm{~d}_{\mathrm{xz}, \mathrm{yz}, \mathrm{z} 2}$ orbitals with $\mathrm{NO} \pi_{\mathrm{x}, \mathrm{y}}{ }^{*}$. The resulting localized orbitals became either majority metal-based or NO-based, and it is important to note that the usage of these orbitals in the CAS-CI expansion of the wave function did not change the overall CAS wave function, only simplified the intuitive, qualitative interpretation in terms of valencebond, resonance-like interpretations. Configurations with sufficiently high coefficients (larger than $0.1 \%$ ), were classified into one of three major resonance structures, $\mathrm{M}^{\mathrm{n}+1}-\mathrm{NO}^{-}, \mathrm{M}^{\mathrm{n}}-\mathrm{NO}$, or $\mathrm{M}^{\mathrm{n}-1}-\mathrm{NO}^{+}$. Coefficients corresponding to the same resonance structure were added together to produce the amount each contributed to the overall ground state. 


\section{Calculated spectra for $\left[\mathrm{Cl}_{3} \mathrm{Fe}(\mathrm{SMe})\right]^{-}$by TD-DFT}

I. TPSSh/def2-TZVP Optimized structure (in XYZ format, $\AA$ )

Energy $=-3082.937579517106$

$\begin{array}{lccc}\mathrm{Fe} & 0.026996000 & 0.000075000 & 0.001670000 \\ \mathrm{Cl} & 1.791985000 & 0.468617000 & -1.304033000 \\ \mathrm{Cl} & -0.430506000 & 1.692784000 & 1.375345000 \\ \mathrm{Cl} & -1.717617000 & -0.505990000 & -1.311550000 \\ \mathrm{~S} & 0.491675000 & -1.779620000 & 1.310019000 \\ \mathrm{C} & 0.693508000 & -3.144655000 & 0.108058000 \\ \mathrm{H} & -0.210690000 & -3.251869000 & -0.490647000 \\ \mathrm{H} & 1.545346000 & -2.948627000 & -0.542927000 \\ \mathrm{H} & 0.869291000 & -4.060550000 & 0.672950000\end{array}$

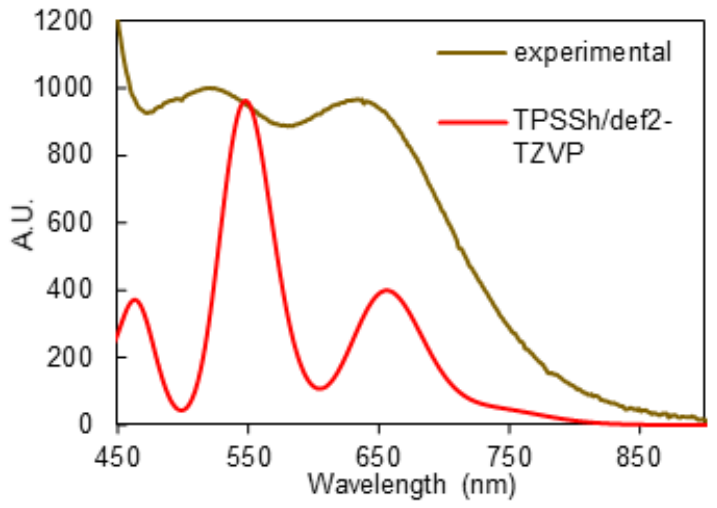

Figure S27. TD-DFT absorption spectrum of $\left[\mathrm{Cl}_{3} \mathrm{Fe}(\mathrm{SMe})\right]^{-}$. TPSSh/def2-TZVP (red) with optimized geometry from the same functional/basis set. These calculated spectra are overlaid with the experimental data of the brown intermediate formed in the reaction between $\left[\mathrm{Cl}_{6} \mathrm{Fe}_{2}{ }_{2}\right]^{2-}$ and $\mathrm{Ph}_{3} \mathrm{CSNO}$ (Figure S7).

\section{$\left[\mathrm{Cl}_{3} \mathrm{FeNO}\right]^{-}(\mathrm{S}=3 / 2)$ electronic structure calculations}

II. BP86/def2-TZVP Optimized structure (in XYZ format, $\AA$ )

Energy $=-2774.999359741336$

$\begin{array}{lccc}\mathrm{Fe} & 0.000713000 & 0.000559000 & -0.018025000 \\ \mathrm{Cl} & -0.683093000 & 2.011583000 & -0.753112000 \\ \mathrm{Cl} & -1.393497000 & -1.599966000 & -0.758218000 \\ \mathrm{Cl} & 2.089574000 & -0.408781000 & -0.740276000 \\ \mathrm{O} & 0.015793000 & 0.000144000 & 2.863216000 \\ \mathrm{~N} & -0.000039000 & 0.000182000 & 1.684604000\end{array}$

CASSCF $(9,13) /$ def2-TZVP calculation results Energy $=-2770.6109816645$

III. Contour plots of the occupied active orbitals (with occupation numbers) resulting from CASSCF $(9,13)$. External (unoccupied) active orbitals are omitted. 


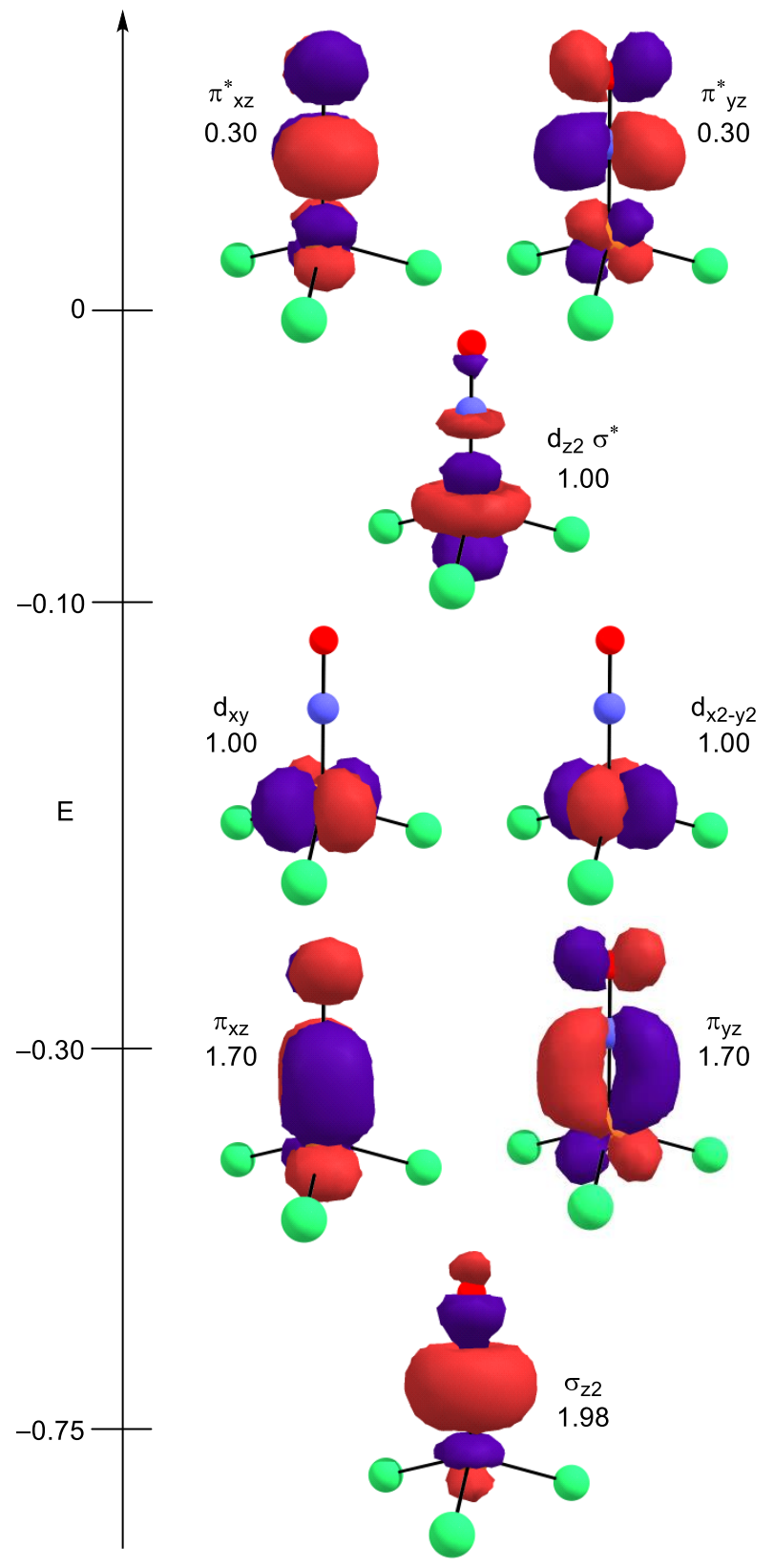

IV. Pipek-Mezey localization of covalent $\mathrm{Fe} 3 \mathrm{~d}-\mathrm{NO} \pi^{*}$ orbitals 


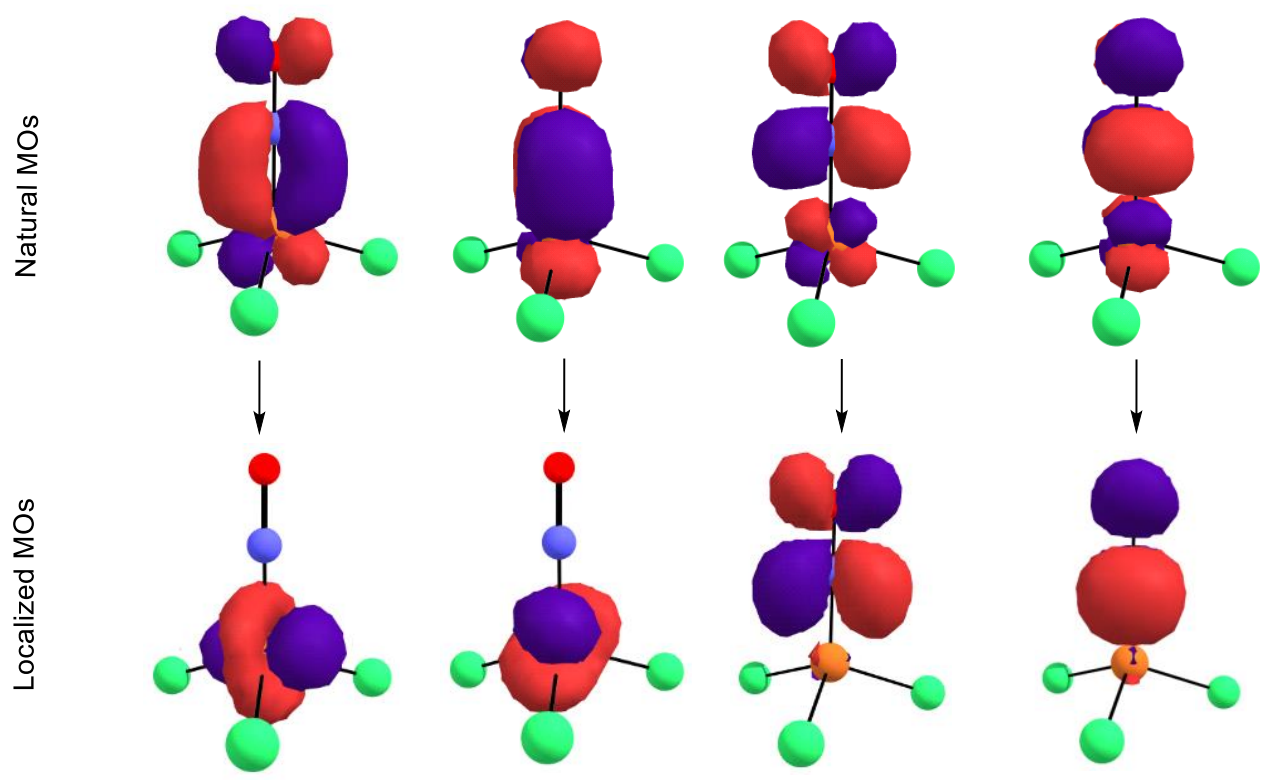

V. Leading configurations $\mathrm{s}^{\mathrm{a}, \mathrm{b}}$ in the basis of localized $\mathrm{Fe} 3 \mathrm{~d}-\mathrm{NO} \pi^{*}$ (Energy of recalculated wavefunction $=-2770.6109816778 \mathrm{Eh})$

\begin{tabular}{ccccccccc}
\hline Fed $d_{x z}$ & $F e d_{y z}$ & $F e d_{x 2-y 2}$ & $F e d_{x y}$ & $F e d_{z 2}$ & NO $p_{x}$ & NO $p_{y}$ & Character & Weight \\
\hline up & up & up & up & up & down & down & Fe(III)-NO ${ }^{-}$ & $46.349 \%$ \\
2 & up & up & up & up & 0 & down & Fe(II)-NO & $15.880 \%$ \\
up & 2 & up & up & up & down & 0 & Fe(II) $-\mathrm{NO}^{*}$ & $15.742 \%$ \\
\hline
\end{tabular}

${ }^{a}$ Additional CSFs with smaller coefficients corresponding to the same $\mathrm{Fe}-\mathrm{NO}$ interactions were added together to arrive at the final weights of each electronic configuration.

${ }^{\mathrm{b}} \mathrm{The} \mathrm{Fe}-\mathrm{NO} \sigma$ bonding orbital is omitted from this table, as the occupation consistently remained 2.

VI. Final weights of the contribution of each resonance structure in $\left[\mathrm{Cl}_{3} \mathrm{FeNO}\right]^{-}$

\begin{tabular}{ll}
\hline Character & Weight \\
\hline $\mathrm{Fe}(\mathrm{IV})-\mathrm{NO}^{2-}$ & $0.804 \%$ \\
$\mathrm{Fe}(\mathrm{III})-\mathrm{NO}^{-}$ & $51.942 \%$ \\
$\mathrm{Fe}(\mathrm{II})-\mathrm{NO}{ }^{\circ}$ & $39.987 \%$ \\
$\mathrm{Fe}(\mathrm{I})-\mathrm{NO}^{+}$ & $2.003 \%$ \\
others & $5.264 \%$ \\
\hline
\end{tabular}




\section{$\left[\mathrm{Cl}_{3} \mathrm{CuNO}^{-}(\mathrm{S}=1 / 2)\right.$ electronic structure calculations}

I. BP86/def2-TZVP Optimized structure (in XYZ format, $\AA$ ) Energy $=-3151.776633291106$

$\begin{array}{lccc}\mathrm{Cu} & -0.004659000 & 0.000000000 & -0.005801000 \\ \mathrm{Cl} & 0.570032000 & -2.159543000 & 0.249660000 \\ \mathrm{Cl} & -2.214884000 & 0.000000000 & -0.315269000 \\ \mathrm{Cl} & 0.570032000 & 2.159543000 & 0.249660000 \\ \mathrm{~N} & 2.012279000 & 0.000000000 & 0.099010000 \\ \mathrm{O} & 2.602220000 & 0.000000000 & -0.903483000\end{array}$

CASSCF $(10,13) /$ def2-TZVP Calculation results

Energy $=-3147.1628378855$

II. Contour plots of the occupied active orbitals (with occupation numbers) resulting from CASSCF(10,13). External (unoccupied) active orbitals are omitted.

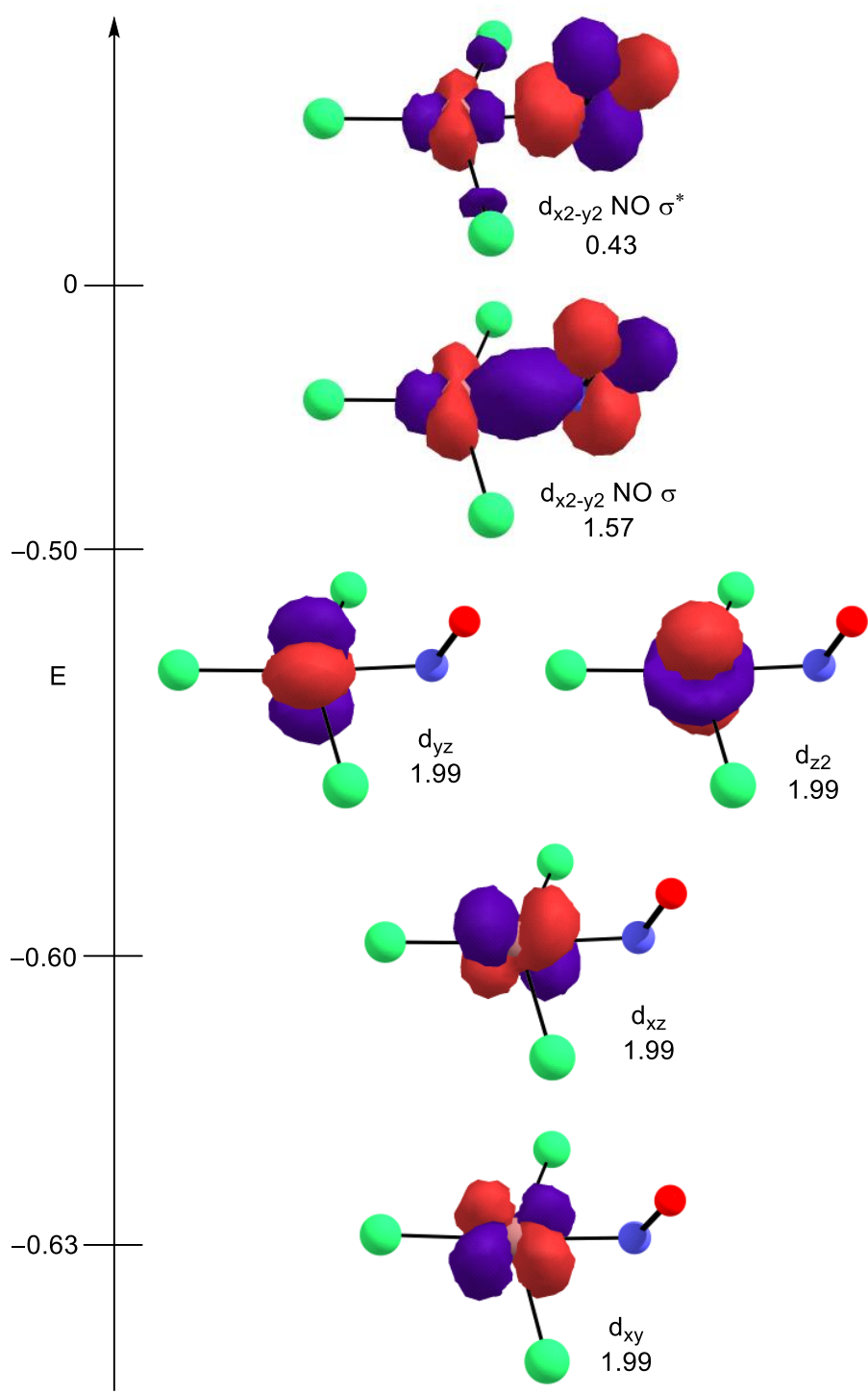


III. Pipek-Mezey localization of covalent $\mathrm{Cu}-\mathrm{NO}$ orbitals

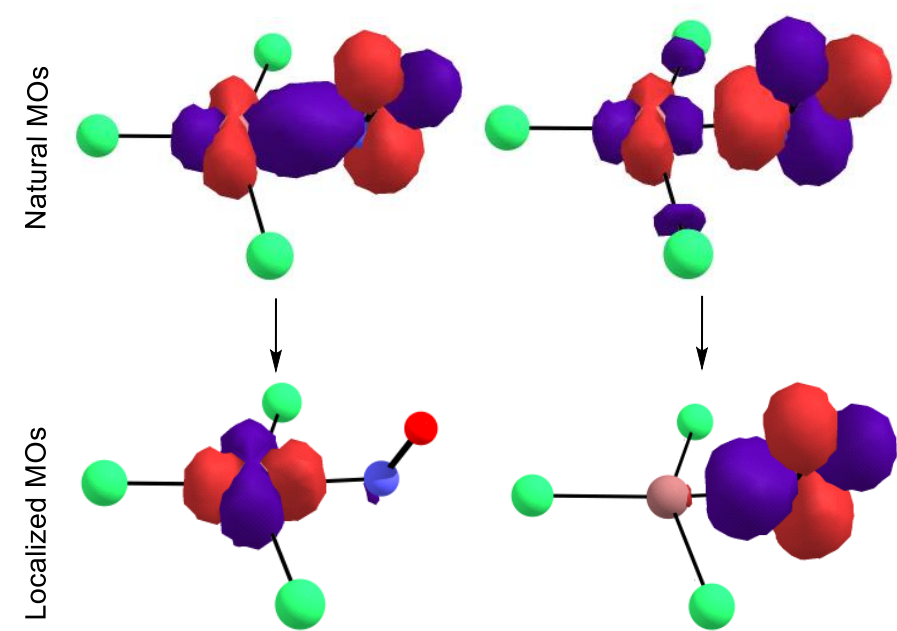

IV. Leading CAS-CI configurations ${ }^{\mathrm{a}}$ in the basis of localized $\mathrm{Cu} 3 \mathrm{~d}-\mathrm{NO}$

\begin{tabular}{lllllllll}
\hline Cud $d_{x z}$ & $C u d_{y z}$ & $C u d_{x 2-y 2}$ & $C u d_{x y}$ & $C u d_{z 2}$ & NO $\pi_{x}^{*}$ & NO $\pi_{y}^{*}$ & Character & Weight \\
\hline 2 & 2 & up & 2 & 2 & down & 0 & $\mathrm{Cu}(\mathrm{II})-\mathrm{NO}$ & $86.374 \%$ \\
2 & 2 & 2 & 2 & 2 & 0 & 0 & $\mathrm{Cu}(\mathrm{I})-\mathrm{NO}^{+}$ & $9.650 \%$ \\
2 & 2 & 2 & 2 & 0 & 2 & 0 & $\mathrm{Cu}(\mathrm{III})-\mathrm{NO}^{-}$ & $1.1165 \%$ \\
\hline
\end{tabular}

aThere were no additional CSF's to add in the $\mathrm{Cu}$-NO case

V. Final weights of each electronic configuration for $\left[\mathrm{Cl}_{3} \mathrm{CuNO}\right]^{-}$

\begin{tabular}{ll}
\hline Character & Weight \\
\hline $\mathrm{Cu}(\mathrm{III})-\mathrm{NO}^{-}$ & $1.1165 \%$ \\
$\mathrm{Cu}(\mathrm{II})-\mathrm{NO} \cdot$ & $86.374 \%$ \\
$\mathrm{Cu}(\mathrm{I})-\mathrm{NO}^{+}$ & $9.650 \%$ \\
others & $2.8595 \%$ \\
\hline
\end{tabular}

\section{$\mathrm{Cl}_{3} \mathrm{Fe}^{\mathrm{III}} \mathrm{NO}(\mathrm{S}=2)$ electronic structure calculations}

I. TPSSh/def2-TZVP Optimized Structure (in XYZ format, $\AA$ )

$\begin{array}{llrl}\text { Energy }= & -2774.553148464734 & & \\ \mathrm{Fe} & 11.614799000 & 9.074563000 & 13.987725000 \\ \mathrm{Cl} & 13.486452000 & 9.885622000 & 13.239533000\end{array}$




$\begin{array}{lccc}\mathrm{Cl} & 10.555486000 & 10.064671000 & 15.604176000 \\ \mathrm{Cl} & 10.401116000 & 7.980873000 & 12.574742000 \\ \mathrm{O} & 12.516805000 & 6.460939000 & 14.830414000 \\ \mathrm{~N} & 12.517340000 & 7.576332000 & 15.048410000\end{array}$

II. $\operatorname{CASSCF}(6,13) /$ def2-TZVP calculation results

Energy $=-2770.462644901734$

III. Contour plots of the occupied active orbitals (with occupation numbers) resulting from $\operatorname{CASSCF}(6,13)$.

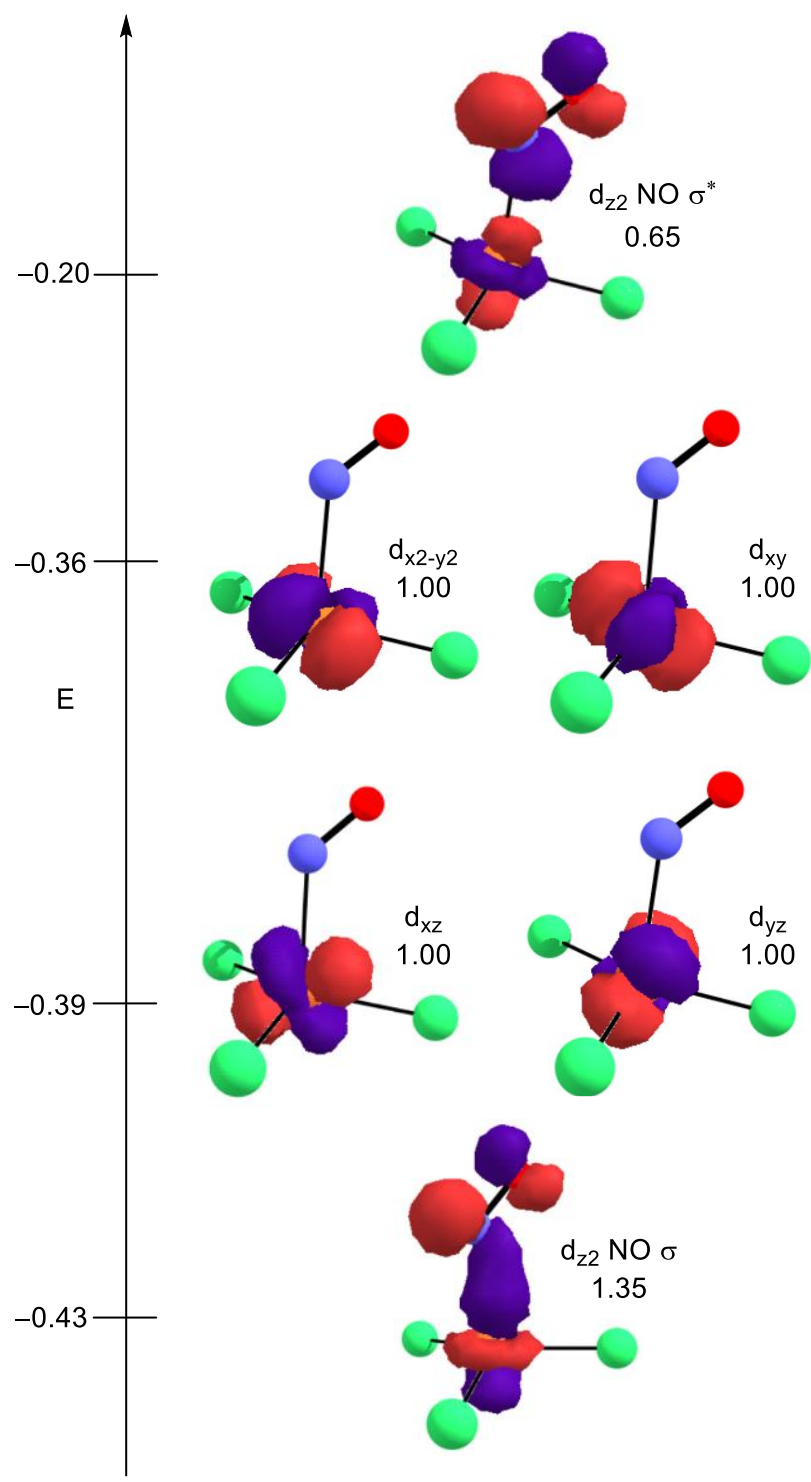


IV. Pipek-Mezey localization of covalent $\mathrm{Fe} 3 \mathrm{~d}-\mathrm{NO} \sigma / \sigma^{*}$ orbitals

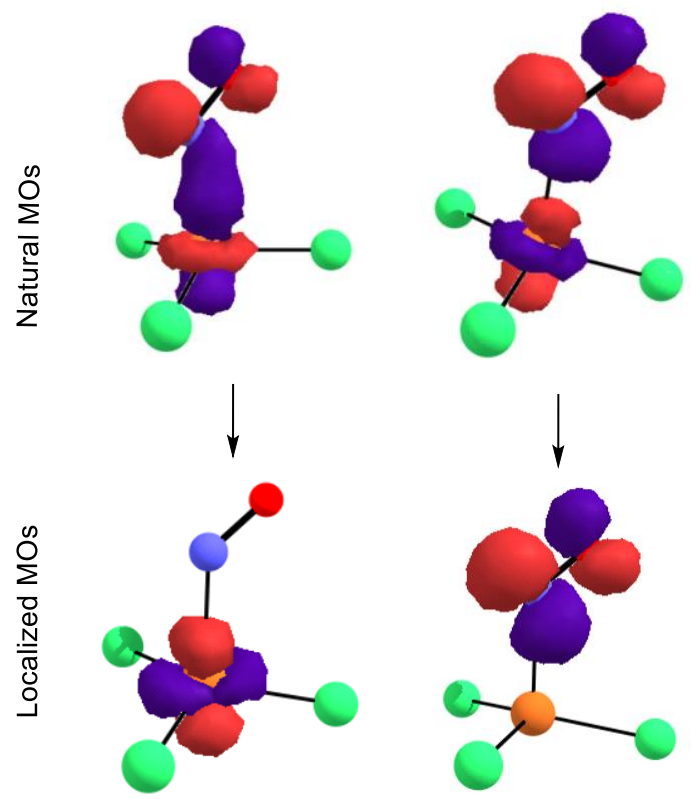

V. Leading CAS-CI configurations ${ }^{\mathrm{a}}$ in the basis of localized $\mathrm{Fe} 3 \mathrm{~d}-\mathrm{NO} \sigma / \sigma^{*}$

\begin{tabular}{llllllll}
\hline Fe $d_{z 2}$ & Fe $d_{x z}$ & Fe $d_{y z}$ & $F e d_{x 2-y 2}$ & $F e d_{x y}$ & NO $\pi_{x}^{*}$ & Character & Weight \\
\hline up & up & up & up & up & down & Fe(III)-NO & $93.161 \%$ \\
2 & up & up & up & up & 0 & Fe(II)-NO NO $^{+}$ & $4.640 \%$
\end{tabular}

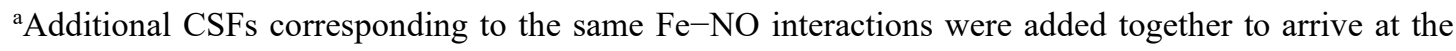
final weights of each electronic configuration.

VI. Final weights of each electronic configuration for $\mathrm{Cl}_{3} \mathrm{Fe}^{\mathrm{III}} \mathrm{NO}$

\begin{tabular}{lc}
\hline Character & Weight \\
\hline $\mathrm{Fe}(\mathrm{III})-\mathrm{NO} \cdot$ & $93.161 \%$ \\
$\mathrm{Fe}(\mathrm{II})-\mathrm{NO}^{+}$ & $4.640 \%$ \\
$\mathrm{Fe}(\mathrm{IV})-\mathrm{NO}^{-}$ & $0.257 \%$ \\
Others & $1.942 \%$ \\
\hline
\end{tabular}




\section{References}

(1) Groysman, S.; Holm, R. H. A Series of Mononuclear Quasi-Two-Coordinate Copper(l) Complexes Employing a Sterically Demanding Thiolate Ligand. Inorg. Chem. 2009, 48, $621-627$.

(2) Melzer, M. M.; Mossin, S.; Cardenas, A. J. P.; Williams, K. D.; Zhang, S.; Meyer, K.; Warren, T. H. A Copper(II) Thiolate from Reductive Cleavage of an S-Nitrosothiol. Inorg. Chem. 2012, 51, 8658-8660.

(3) Arulsamy, N.; Bohle, D. S.; Butt, J. A.; Irvine, G. J.; Jordan, P. A.; Sagan, E. Interrelationships between Conformational Dynamics and the Redox Chemistry of SNitrosothiols. J. Am. Chem. Soc. 1999, 121, 7115-7123.

(4) Hay, M. T.; Geib, S. J. Tetrabutylammonium Tetrachloroferrate(III). Acta Crystallogr. Sect. E Struct. Reports Online 2005, 61, m190-m191.

(5) Carlson, M. R.; Gray, D. L.; Richers, C. P.; Wang, W.; Zhao, P. H.; Rauchfuss, T. B.; Pelmenschikov, V.; Pham, C. C.; Gee, L. B.; Wang, H.; Cramer, S. P. Sterically Stabilized Terminal Hydride of a Diiron Dithiolate. Inorg. Chem. 2018, 57, 1988-2001.

(6) Comba, P.; Gahan, L. R.; Mereacre, V.; Hanson, G. R.; Powell, A. K.; Schenk, G.; Zajaczkowski-Fischer, M. Spectroscopic Characterization of the Active Fe IIIfe III and Fe IIIfe II Forms of a Purple Acid Phosphatase Model System. Inorg. Chem. 2012, 51, $12195-12209$.

(7) Cardenas, A. J. P.; Culotta, B. J.; Warren, T. H.; Grimme, S.; Stute, A.; Fröhlich, R.; Kehr, G.; Erker, G. Capture of NO by a Frustrated Lewis Pair: A New Type of Persistent N-Oxyl Radical. Angew. Chemie - Int. Ed. 2011, 50, 7567-7571.

(8) Vinet, L.; Zhedanov, A. A "missing" Family of Classical Orthogonal Polynomials. Journal of Physics A: Mathematical and Theoretical. 2011, pp 1689-1699.

(9) Sun, J. S.; Zhao, H.; Ouyang, X.; Clérac, R.; Smith, J. A.; Clemente-Juan, J. M.; GómezGarcia, C.; Coronado, E.; Dunbar, K. R. Structures, Magnetic Properties, and Reactivity Studies of Salts Containing the Dinuclear Anion $\left[\mathrm{M}_{2} \mathrm{Cl}_{6}\right]^{2-}(\mathrm{M}=\mathrm{Mn}, \mathrm{Fe}, \mathrm{Co})$. Inorg. Chem. 1999, 38, 5841-5855.

(10) In-Iam, A.; Wolf, M.; Wilfer, C.; Schaniel, D.; Woike, T.; Klüfers, P. \{FeNO $\}^{7}$-Type Halogenido Nitrosyl Ferrates: Syntheses, Bonding, and Photoinduced Linkage 
Isomerism. Chem. - A Eur. J. 2019, 25, 1304-1325.

(11) Harrop, T. C.; Song, D.; Lippard, S. J. Interaction of Nitric Oxide with Tetrathiolato Iron(II) Complexes: Relevance to the Reaction Pathways of Iron Nitrosyls in SulfurRich Biological Coordination Environments. J. Am. Chem. Soc. 2006, 128, 3528-3529.

(12) Chang, S.; Koch, S. A. $\left[\mathrm{Fe}^{\mathrm{III}}(\mathrm{SR})_{4}\right]^{1-}$ Complexes Can Be Synthesized by the Direct Reaction of Thiolates with FeCl3. J. Inorg. Biochem. 2007, 101, 1758-1759.

(13) Holm, R. H.; Lo, W. Structural Conversions of Synthetic and Protein-Bound Iron-Sulfur Clusters. Chem. Rev. 2016, 116, 13685-13713.

(14) Hay, M. T.; Geib, S. J. Tetrabutylammonium Tetrachloroferrate(III). Acta Crystallogr. Sect. E Struct. Reports Online 2005, 61, m190-m191.

(15) Bruker-Analytical X-ray Services. SHELXTL-PC, Vers. 5.10. Universität Göttingen: Göttingen, Germany 1998.

(16) Barbour, L. XSEED. 1999.

(17) Blessing, R. H. An Empirical Correction for Absorption Anisotropy. Acta Crystallogr. Sect. A 1995, 51, 33-38.

(18) Neese, F. Software Update: The ORCA Program System, Version 4.0. Wiley Interdiscip. Rev. Comput. Mol. Sci. 2018, 8, e1327.

(19) Becke, A. D. Density-Functional Exchange-Energy Approximation with Correct Asymptotic Behavior; 1988; Vol. 38.

(20) Perdew, J. P. Density-Functional Approximation for the Correlation Energy of the Inhomogeneous Electron Gas; 1986; Vol. 33.

(21) Weigend, F.; Ahlrichs, R. Balanced Basis Sets of Split Valence, Triple Zeta Valence and Quadruple Zeta Valence Quality for H to Rn: Design and Assessment of Accuracy. Phys. Chem. Chem. Phys. 2005, 7, 3297-3305.

(22) Tao, J.; Perdew, J. P.; Staroverov, V. N.; Scuseria, G. E. Climbing the Density Functional Ladder: Nonempirical Meta-Generalized Gradient Approximation Designed for Molecules and Solids. Phys. Rev. Lett. 2003, 91.

(23) Grimme, S.; Antony, J.; Ehrlich, S.; Krieg, H. A Consistent and Accurate Ab Initio Parametrization of Density Functional Dispersion Correction (DFT-D) for the 94 Elements H-Pu. J. Chem. Phys. 2010, 132, 154104. 
(24) Werner, H. J.; Knowles, P. J. A Second Order Multiconfiguration SCF Procedure with Optimum Convergence. J. Chem. Phys. 1985, 82, 5053-5063.

(25) Knowles, P. J.; Werner, H. J. An Efficient Second-Order MC SCF Method for Long Configuration Expansions. Chem. Phys. Lett. 1985, 115, 259-267.

(26) Aquilante, F.; Bondo Pedersen, T.; Sánchez De Merás, A.; Koch, H. Fast Noniterative Orbital Localization for Large Molecules. J. Chem. Phys. 2006, 125, 174101.

Gaussian16 full reference:

Gaussian 16, Revision C.01, Frisch, M. J.; Trucks, G. W.; Schlegel, H. B.; Scuseria, G. E.; Robb, M. A.; Cheeseman, J. R.; Scalmani, G.; Barone, V.; Petersson, G. A.; Nakatsuji, H.; Li, X.; Caricato, M.; Marenich, A. V.; Bloino, J.; Janesko, B. G.; Gomperts, R.; Mennucci, B.; Hratchian, H. P.; Ortiz, J. V.; Izmaylov, A. F.; Sonnenberg, J. L.; Williams-Young, D.; Ding, F.; Lipparini, F.; Egidi, F.; Goings, J.; Peng, B.; Petrone, A.; Henderson, T.; Ranasinghe, D.; Zakrzewski, V. G.; Gao, J.; Rega, N.; Zheng, G.; Liang, W.; Hada, M.; Ehara, M.; Toyota, K.; Fukuda, R.; Hasegawa, J.; Ishida, M.; Nakajima, T.; Honda, Y.; Kitao, O.; Nakai, H.; Vreven, T.; Throssell, K.; Montgomery, J. A., Jr.; Peralta, J. E.; Ogliaro, F.; Bearpark, M. J.; Heyd, J. J.; Brothers, E. N.; Kudin, K. N.; Staroverov, V. N.; Keith, T. A.; Kobayashi, R.; Normand, J.; Raghavachari, K.; Rendell, A. P.; Burant, J. C.; Iyengar, S. S.; Tomasi, J.; Cossi, M.; Millam, J. M.; Klene, M.; Adamo, C.; Cammi, R.; Ochterski, J. W.; Martin, R. L.; Morokuma, K.; Farkas, O.; Foresman, J. B.; Fox, D. J. Gaussian, Inc., Wallingford CT, 2016. 